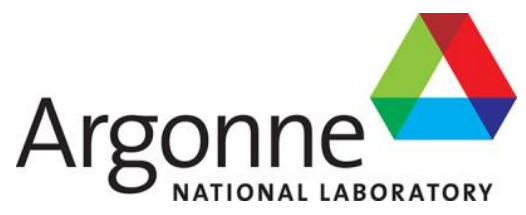

\title{
Irradiation Experiment Conceptual Design Parameters for MURR LEU U-Mo Fuel Conversion
}

Revision 1

Nuclear Engineering Division 


\begin{abstract}
About Argonne National Laboratory
Argonne is a U.S. Department of Energy laboratory managed by UChicago Argonne, LLC under contract DE-AC02-06CH11357. The Laboratory's main facility is outside Chicago, at 9700 South Cass Avenue, Argonne, Illinois 60439. For information about Argonne and its pioneering science and technology programs, see www.anl.gov.
\end{abstract}

\title{
Availability of This Report
}

This report is available, at no cost, at http://www.osti.gov/bridge. It is also available on paper to the U.S. Department of Energy and its contractors, for a processing fee, from:

U.S. Department of Energy

Office of Scientific and Technical Information

P.O. Box 62

Oak Ridge, TN 37831-0062

phone (865) 576-8401

fax (865) 576-5728

reports@adonis.osti.gov

\section{Disclaimer}

This report was prepared as an account of work sponsored by an agency of the United States Government. Neither the United States Government nor any agency thereof, nor UChicago Argonne, LLC, nor any of their employees or officers, makes any warranty, express or implied, or assumes any legal liability or responsibility for the accuracy, completeness, or usefulness of any information, apparatus, product, or process disclosed, or represents that its use would not infringe privately owned rights. Reference herein to any specific commercial product, process, or service by trade name, trademark, manufacturer, or otherwise, does not necessarily constitute or imply its endorsement, recommendation, or favoring by the United States Government or any agency thereof. The views and opinions of document authors expressed herein do not necessarily state or reflect those of the United States Government or any agency thereof, Argonne National Laboratory, or UChicago Argonne, LLC. 
ANL/RERTR/TM-13-1

Revision 1

\section{Irradiation Experiment Conceptual Design Parameters for MURR LEU U-Mo Fuel Conversion}

Revision 1

prepared by

J. Stillman ${ }^{1}$, E. Feldman ${ }^{1}$, J. Stevens ${ }^{1}$, E. Wilson ${ }^{1}$, L. Foyto ${ }^{2}$, K. Kutikkad ${ }^{2}$, J. C. McKibben ${ }^{2}$, and N. Peters ${ }^{2}$

${ }^{1}$ GTRI Reactor Conversion Program, Nuclear Engineering Division, Argonne National Laboratory ${ }^{2}$ University of Missouri-Columbia Research Reactor

June 2013

This work is sponsored by the U.S. Department of Energy,

National Nuclear Security Administration Office of Global Threat Reduction (NA-21) 
ANL/RERTR/TM-13-1

Revision 1

(This page intentionally left blank) 


\begin{abstract}
This report contains the results of reactor design and performance calculations for conversion of the University of Missouri Research Reactor (MURR) from the use of highly-enriched uranium (HEU) fuel to the use of low-enriched uranium (LEU) fuel. The analyses were performed by staff members of the Global Threat Reduction Initiative (GTRI) Reactor Conversion Program at the Argonne National Laboratory (ANL) and the MURR Facility. The core conversion to LEU is being performed with financial support from the U. S. government.

In the framework of its non-proliferation policies, the international community presently aims to minimize the amount of nuclear material available that could be used for nuclear weapons. In this geopolitical context most research and test reactors, both domestic and international, have started a program of conversion to the use of LEU fuel. A new type of LEU fuel based on an alloy of uranium and molybdenum (U-Mo) is expected to allow the conversion of U.S. domestic high performance reactors like MURR. This report presents the nominal steady-state irradiation conditions of a key set of plates containing peak irradiation parameters found in MURR cores fueled with the LEU monolithic U-Mo alloy fuel with $10 \mathrm{wt} \%$ Mo. Manufacturing tolerances and other uncertainties in reactor geometry and materials are also presented and used to estimate the uncertainties in these irradiation parameters above nominal steady-state conditions.
\end{abstract}


ANL/RERTR/TM-13-1

Revision 1

(This page intentionally left blank) 


\section{TABLE OF CONTENTS}

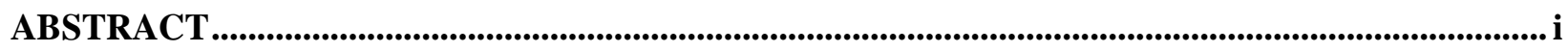

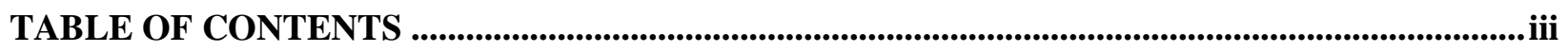

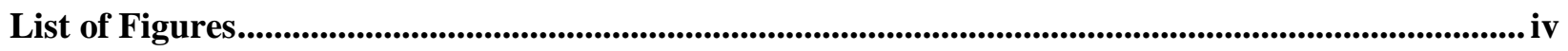

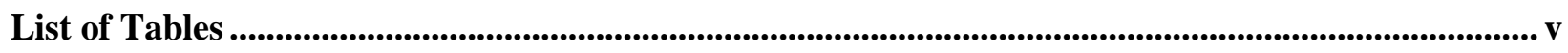

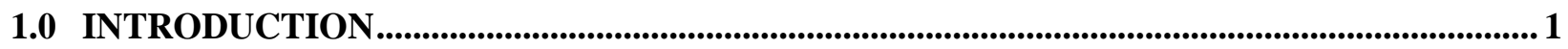

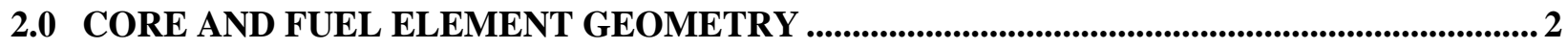

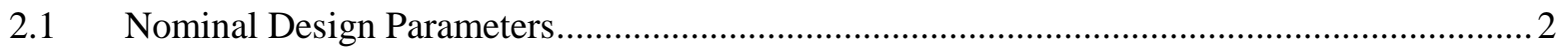

2.2 Element Design Parameters and Tolerances ....................................................................... 5

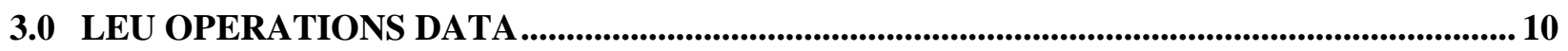

3.1 Scope of Steady-State Core Conditions Evaluated ......................................................... 10

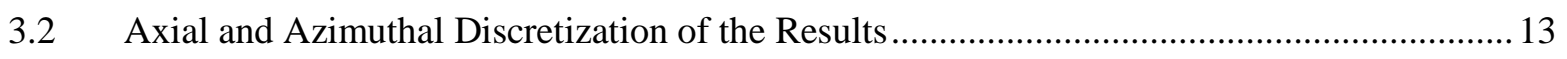

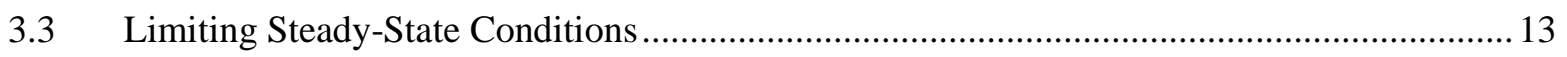

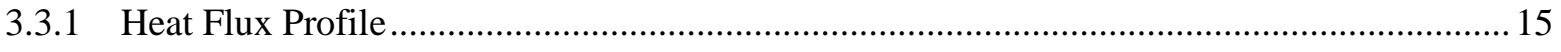

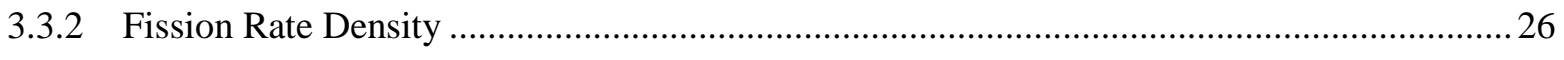

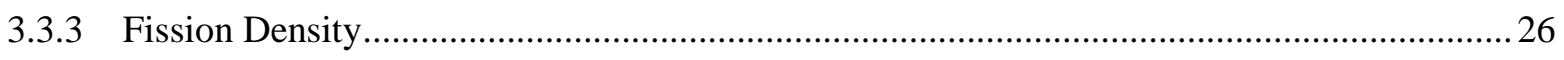

3.3.4 Steady-State Temperatures for LEU Fuel in Plates with Peak Irradiation Conditions ............ 36

4.0 LEU IRRADIATION PARAMETERS WITH UNCERTAINTIES .......................................41

5.0 SUMMARY OF NOMINAL MURR IRRADIATION PARAMETERS ................................... 42

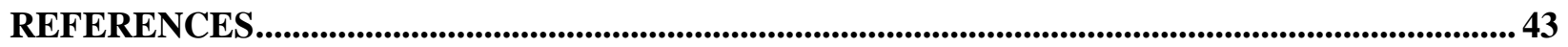




\section{$\underline{\text { List of Figures }}$}

Figure 2.1. Cross-Sectional Views of MURR............................................................................. 2

Figure 2.2. Cross-Sectional View of MURR Fuel Element Plates. .................................................. 2

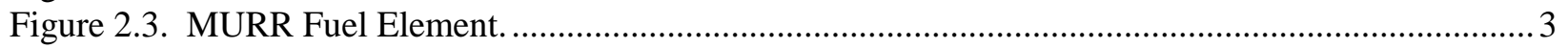

Figure 2.4. Cross Section View of MURR LEU Element Plates 1-5 and 19-23. .................................. 4

Figure 2.5. Cross Sectional View of LEU Fuel Plate. .................................................................... 9

Figure 3.1. Heat Flux $\left(\mathrm{W} / \mathrm{cm}^{2}\right)$ for Fresh LEU Fuel Plate in Core 5B1: Position X6, No Xe, Plate 23, Empty FT.

Figure 3.2. Heat Flux $\left(\mathrm{W} / \mathrm{cm}^{2}\right)$ for LEU Fuel Plate in Core 7A1: Position X8 (170 MWd), No Xe, Plate 22, FT loaded with typical samples.

Figure 3.3. Evolution of Heat Flux $\left(\mathrm{W} / \mathrm{cm}^{2}\right)$ for LEU Fuel Plate in Core 7A: Element burnups at 0 and $77 \mathrm{MWd}$.

Figure 3.4. Evolution of Heat Flux $\left(\mathrm{W} / \mathrm{cm}^{2}\right)$ for LEU Fuel Plate in Core 7A: Element burnups at 96 and $170 \mathrm{MWd}$ .25

Figure 3.5. Fission Rate Density (fissions $/ \mathrm{cm}^{3}-\mathrm{s}$ ) for Fresh LEU Fuel Plate in Core 5B1: Position X7, No Xe, Plate 1, Empty FT. .28

Figure 3.6. Evolution of Fission Rate Density (fissions $/ \mathrm{cm}^{3}$-s) for LEU Fuel Plate in Core 7A: Element burnups at 0 and $77 \mathrm{MWd}$. .33

Figure 3.7. Evolution of Fission Rate Density (fissions $/ \mathrm{cm}^{3}$-s) for LEU Fuel Plate in Core 7A: Element burnups at 96 and $170 \mathrm{MWd}$. 34

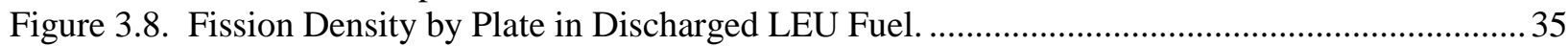

Figure 3.9. Axial Profile of Discharge Fission Density in LEU Fuel Plates..............................................36

Figure 3.10. Oxide Growth Rate Correlation for LEU Fuel Element in MURR. ................................... 38 


\section{$\underline{\text { List of Tables }}$}

Table 2.1. Nominal LEU Fuel Element and Plate Dimensions and Loadings......................................... 4

Table 2.2. Summary of Element Design Parameters and Tolerances....................................................... 6

Table 3.1. Nomenclature for LEU Core Case Names: $c f b$ (e.g. 5B1) ................................................ 11

Table 3.2. Summary of Power Distribution Evaluations for LEU Cores............................................... 12

Table 3.3. Beginning-of-Cycle Burnups for Reference LEU Mixed Burnup Core $(c=7,8) \ldots \ldots \ldots \ldots \ldots \ldots \ldots . . . .13$

Table 3.4. Summary of Key Hot-Stripe and Local Heating Rates Evaluated for LEU Cores................... 14

Table 3.5. Peak Fission Rate Density for Various Cores. ..................................................................... 15

Table 3.6. Maximum Heat Flux (W/ $\left.\mathrm{cm}^{2}\right)$ of All Steady-State Cores: Fresh LEU Element in Core 5B1, Position X6, No Xe, Plate 23, Empty FT.................................................................. 16

Table 3.7. Heat Flux $\left(\mathrm{W} / \mathrm{cm}^{2}\right)$ for LEU Plate with Maximum Fuel Temperature: Core 7A1, Position X8 (170 MWd), No Xe, Plate 22, FT loaded with typical samples.......................... 18

Table 3.8. Heat Flux $\left(\mathrm{W} / \mathrm{cm}^{2}\right)$ in Reference Mixed Burnup Core: Core 7A, Position X1 (0 MWd), No Xe, Plate 22, FT loaded with typical samples............................................................... 20

Table 3.9. Heat Flux $\left(\mathrm{W} / \mathrm{cm}^{2}\right)$ in Reference Mixed Burnup Core: Core 7A, Position X7 (77 MWd), No Xe, Plate 22, FT loaded with typical samples................................................................. 21

Table 3.10. Heat Flux $\left(\mathrm{W} / \mathrm{cm}^{2}\right)$ in Reference Mixed Burnup Core: Core 7A, Position X6 (96 MWd), No Xe, Plate 22, FT loaded with typical samples................................................................. 22

Table 3.11. Heat Flux $\left(\mathrm{W} / \mathrm{cm}^{2}\right)$ in Reference Mixed Burnup Core: Core 7A, Position X8 (170 $M W d)$, No Xe, Plate 22, FT loaded with typical samples. 23

Table 3.12. Maximum Fission Rate Density (fissions $/ \mathrm{cm}^{3}-\mathrm{s}$ ) of All Steady-State Cores: Fresh LEU Element in Core 5B1, Position X7, No Xe, Plate 1, Empty FT.

Table 3.13. Fission Rate Density (fissions/ $\mathrm{cm}^{3}-\mathrm{s}$ ) in Reference Mixed Burnup Core: Core 7A, Position X5 (0 MWd), No Xe, Plate 1, FT loaded with typical samples.

Table 3.14. Fission Rate Density (fissions $/ \mathrm{cm}^{3}-\mathrm{s}$ ) in Reference Mixed Burnup Core: Core 7A, Position X3 (77 MWd), No Xe, Plate 1, FT loaded with typical samples.

Table 3.15. Fission Rate Density (fissions $/ \mathrm{cm}^{3}-\mathrm{s}$ ) in Reference Mixed Burnup Core: Core 7A, Position X2 (96 MWd), No Xe, Plate 1, FT loaded with typical samples.

Table 3.16. Fission Rate Density (fissions $/ \mathrm{cm}^{3}-\mathrm{s}$ ) in Reference Mixed Burnup Core: Core 7A, Position X4 (170 MWd), No Xe, Plate 1, FT loaded with typical samples............................... 32

Table 3.17. Plate Discharge Fission Density for LEU Fuel. ................................................................... 35

Table 3.18. Discharge Fission Density $\left(x 10^{20}\right.$ fissions $\left./ \mathrm{cm}^{3}\right)$ in LEU Fuel Plates................................... 36

Table 3.19. Nominal MURR Core Operating Parameters with LEU Fuel............................................. 37

Table 3.20. Thermal Conductivity Values for LEU Fuel Plate Materials $(W / m-C)$............................... 37

Table 3.21. Steady-State Temperatures of LEU Plate with Maximum Fission Rate Density: Fresh LEU Element in Core 5B1, Position X7, No Xe, Plate 1, Empty FT.

Table 3.22. Steady-State Temperatures of LEU Plate with Maximum Mixed Core Fission Rate Density: Fresh LEU Element in Core 7A, Position X5, No Xe, Plate 1, FT loaded.

Table 3.23. Steady-State Temperatures of LEU Plate with Maximum Heat Flux: Fresh LEU Element in Core 5B1, Position X6, No Xe, Plate 23, Empty FT.....

Table 3.24. Steady-State Temperatures of LEU Plate with Maximum Fuel Temperature:

Depleted LEU Element in Core 7A1, Position X8, No Xe, Plate 22, FT loaded. 40

Table 4.1. Maximum Irradiation Parameters and Uncertainties Assumed for LEU Fuel. 
ANL/RERTR/TM-13-1

Revision 1

(This page intentionally left blank) 


\subsection{INTRODUCTION}

The University of Missouri is working in conjunction with the Global Threat Reduction Initiative (GTRI) Reactor Conversion Program at Argonne National Laboratory (ANL) to perform fuel element design and fuel cycle performance analyses [1], and steady-state thermal-hydraulic safety analyses [2] to support conversion of the University of Missouri Research Reactor (MURR) from highly-enriched uranium (HEU) to low-enriched uranium (LEU) fuel. The conversion objectives are to develop a fuel element design that will ensure safe reactor operations, acceptable shutdown and safety margins, as well as maintain the existing experimental performance of the facility.

An LEU fuel element was designed by staff members of the GTRI Reactor Conversion (RC) Program at ANL and the MURR Facility. A set of assumptions to reliably manufacture the fuel plates were provided by the Fuel Development (FD) and Fuel Fabrication Capability (FFC) pillars of the GTRI Reduced Enrichment for Research and Test Reactors (RERTR) program. Consequently, the dimensions of the element were developed to meet the conversion goals and provide the best fuel cycle performance, while adhering to this set of manufacturing assumptions. Reference 1 describes the fuel design process.

The proposed LEU fuel element has an overall design and exterior dimensions that are similar to those of the current HEU fuel elements. There are 23 fuel plates in the LEU design. The overall thickness of each plate is 44 mil, except for the exterior plate that is furthest from the center flux trap (plate 23), which is 49 mil thick. The proposed LEU fuel plates have U-10Mo monolithic fuel foils with a ${ }^{235} \mathrm{U}$ enrichment of $19.75 \%$ varying from 9 mil to 20 mil thick, and clad with Al-6061 aluminum. A thin layer of zirconium exists between the fuel foils and the aluminum cladding as a diffusion barrier. The thinnest nominal combined zirconium and aluminum clad thickness on each side of the fuel plates is 12 mil.

The LEU U-10Mo monolithic fuel is not yet qualified as driver fuel in research reactors, but is under intense development under the auspices of the GTRI FD and FFC programs. To assist in the design of mini- and full-size plates for the irradiation experiments, as well as the planning and execution of the experimental campaign, calculated performance parameters have been compiled and are presented in this report.

A number of core states that could exist during steady-state operations of the MURR were examined in Reference 1. These core states included variations in the mix of fuel element burnup loaded in the core, the core xenon buildup state, center flux trap contents, and control blade state. In this report, performance parameters are presented for the LEU elements under the conditions that are expected in steady-state operations in the MURR that will yield the highest plate heat flux, fuel and clad temperatures, fission rate density, and cumulative fission density. 


\subsection{CORE AND FUEL ELEMENT GEOMETRY}

\subsection{Nominal Design Parameters}

The MURR core has a fixed geometry consisting of eight fuel elements, each having identical physical dimensions. The fuel elements are placed vertically around an annulus between two cylindrical aluminum reactor pressure vessels. Cross-sectional views of the MURR reactor core and a close-up view of the core are shown in Figure 2.1.

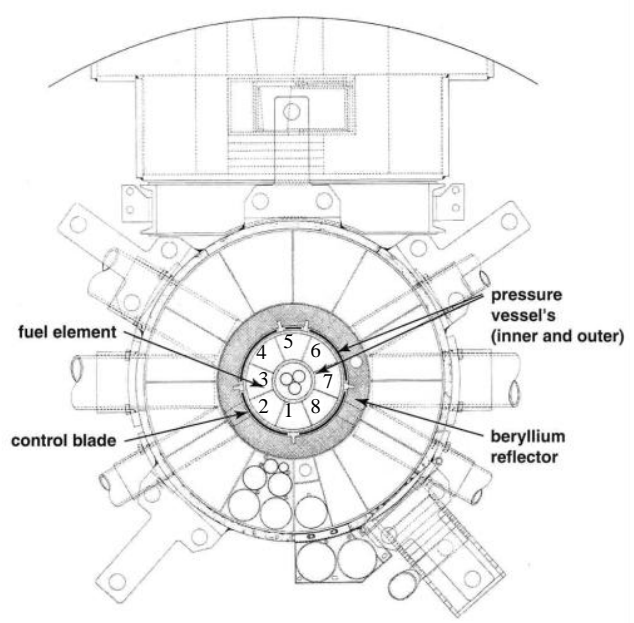

MURR Reactor

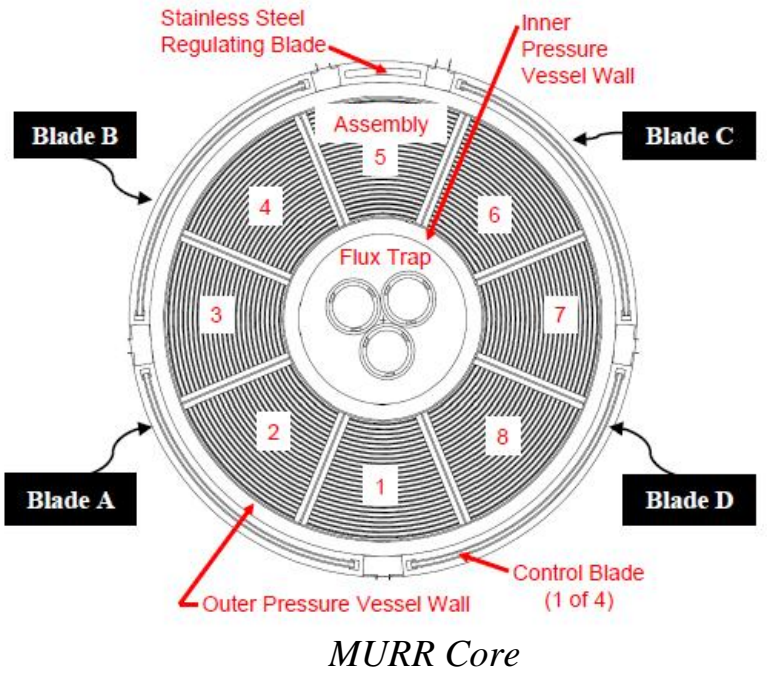

MURR Core

Figure 2.1. Cross-Sectional Views of MURR.

The current HEU fuel element used in MURR has 24 curved plates that form a 45-degree arc. A crosssectional drawing of the fuel plates in the element is shown in Figure 2.2. The HEU fuel plates are 50 mil thick (0.050 inches). The fuel meat is 20 mil thick in each plate and consists of $\mathrm{UAl}_{\mathrm{x}}$ aluminide fuel containing uranium with a ${ }^{235} \mathrm{U}$ enrichment of approximately $93 \%$. The HEU plates are nominally clad with 15 mil of Al-6061 aluminum. The fuel plates are 25.5 inches long, with an active fuel meat length of 24 inches. While the plate and meat width varies by plate, each plate has two unfueled edges that are each 145 mil wide.

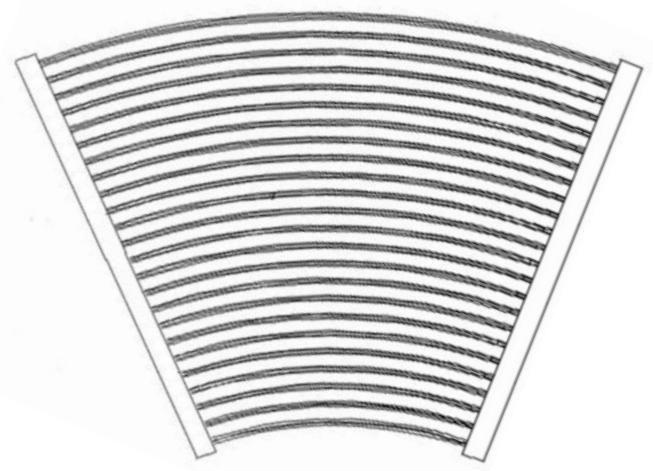

Figure 2.2. Cross-Sectional View of MURR Fuel Element Plates. 
Figure 2.3 provides an illustration of the MURR fuel element. The fuel plates are swaged into two Al6061 aluminum side plates that are 0.150 inches (150 mil) thick, 3.16 inches wide, and 31.75 inches long. The plates fit into grooves cut into the side plate that are 75 mil deep, leaving $70 \pm 30$ mil of the unfueled portion of the fuel plate that extends out of the side plate. A comb is attached over the fuel plates at their top and bottom to provide additional structural support and help maintain fuel plate spacing. The side plates are attached to the top and bottom end fittings. Rollers on the inside and outside edges of the end fittings facilitate insertion of the elements into the annular pressure vessel of the MURR. They also ensure that the minimum outer channel clearances are maintained. The overall length of the element is 32.5 inches.
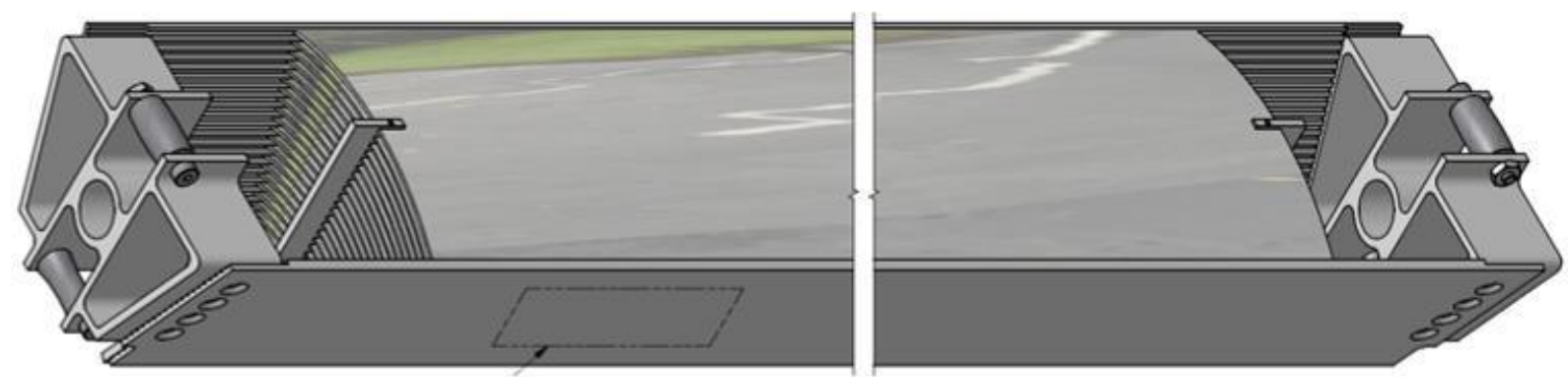

Figure 2.3. MURR Fuel Element.

In order to meet the reactivity requirements of the MURR operating cycle with LEU fuel, it is necessary to have a much higher uranium density than the currently qualified $\mathrm{UAl}_{\mathrm{x}}$ or silicide dispersion fuels. [3] $\mathrm{U}-10 \mathrm{Mo}$ monolithic foils that can provide a uranium density of $15.3 \mathrm{gU} / \mathrm{cm}^{3}$ have been selected for the LEU fuel, pending successful fuel qualification. A fuel element design with U-10Mo LEU fuel developed in Reference 1 was found to safely meet the MURR operating cycle requirements and maintain existing reactor performance.

The LEU fuel element has 23 fuel plates. Each fuel plate is 25.5 inches long, with a 24.0 inch fueled length. The unfueled edge on each side of the fuel plates is $145 \mathrm{mil}$, of which 75 mil extends into a groove cut into the element side plates. The other portions of the element construction (e.g., side plate length, width, and thickness; and end fittings) will be identical to the HEU fuel element.

A summary of the LEU design parameters is provided in Table 2.1. The LEU element uses graded foil thicknesses to flatten the radial heat flux profile. This can be seen in Figure 2.4 which shows a cross sectional view of the MURR LEU element plates 1-5 and 19-23. Note that plates 6-18 have the same fuel meat and clad thicknesses as plates 4-5 and 19-22. The clad thickness varies by plate, with the thinnest nominal clad being 12 mil. The clad thicknesses on plates 1 and 23 are thicker (17.5 and 16 mil, respectively) because the outer plates are more susceptible to being scratched during handling. The fuel cladding consists of Al-6061 aluminum and a thin (1 mil) zirconium layer at the fuel-clad interface as an interaction barrier. Plates 1 through 22 are designed to have a nominal thickness of 44 mil. Making the plates thinner than the HEU fuel element, as well having one less plate, gives a higher water-to-fuel ratio in the LEU element and increases the reactivity. Plate 23 is the widest fuel plate and is designed to have a nominal thickness of 49 mil. This gives greater resistance against bending forces in the MURR coolant flow field. 
Table 2.1. Nominal LEU Fuel Element and Plate Dimensions and Loadings.

\begin{tabular}{|c|c|c|c|c|c|c|c|}
\hline $\begin{array}{c}\text { Channel } \\
\text { or Plate }\end{array}$ & $\begin{array}{c}\text { Meat } \\
\text { thickness } \\
(\text { mil) }\end{array}$ & $\begin{array}{c}\text { Al-6061+Zr } \\
\text { Clad } \\
\text { thickness } \\
(\text { mil) }\end{array}$ & $\begin{array}{c}\text { Plate } \\
\text { thickness } \\
\text { (mil) }\end{array}$ & $\begin{array}{c}\text { Coolant } \\
\text { Channel } \\
\text { thickness } \\
\text { (mil) }\end{array}$ & $\begin{array}{c}\text { Clad I.R. } \\
\text { (inches) }\end{array}$ & $\begin{array}{c}\text { Nominal } \\
\text { Meat width } \\
\text { (inches) }\end{array}$ & $\begin{array}{c}235 \\
\text { Content } \\
(\text { grams) })^{2}\end{array}$ \\
\hline 1 & 9 & 17.5 & 44 & $80.5^{3}$ & 2.7555 & 1.6895 & 18.09 \\
\hline 2 & 12 & 16 & 44 & 93 & 2.8925 & 1.7971 & 25.66 \\
\hline 3 & 16 & 14 & 44 & 93 & 3.0295 & 1.9047 & 36.26 \\
\hline 4 & 20 & 12 & 44 & 93 & 3.1665 & 2.0123 & 47.89 \\
\hline 5 & 20 & 12 & 44 & 93 & 3.3035 & 2.1199 & 50.45 \\
\hline 6 & 20 & 12 & 44 & 92 & 3.4395 & 2.2267 & 52.99 \\
\hline 7 & 20 & 12 & 44 & 92 & 3.5755 & 2.3335 & 55.53 \\
\hline 8 & 20 & 12 & 44 & 92 & 3.7115 & 2.4403 & 58.07 \\
\hline 9 & 20 & 12 & 44 & 92 & 3.8475 & 2.5472 & 60.61 \\
\hline 10 & 20 & 12 & 44 & 92 & 3.9835 & 2.6540 & 63.16 \\
\hline 11 & 20 & 12 & 44 & 92 & 4.1195 & 2.7608 & 65.70 \\
\hline 12 & 20 & 12 & 44 & 92 & 4.2555 & 2.8676 & 68.24 \\
\hline 13 & 20 & 12 & 44 & 92 & 4.3915 & 2.9744 & 70.78 \\
\hline 14 & 20 & 12 & 44 & 92 & 4.5275 & 3.0812 & 73.32 \\
\hline 15 & 20 & 12 & 44 & 92 & 4.6635 & 3.1880 & 75.86 \\
\hline 16 & 20 & 12 & 44 & 92 & 4.7995 & 3.2949 & 78.41 \\
\hline 17 & 20 & 12 & 44 & 92 & 4.9355 & 3.4017 & 80.95 \\
\hline 18 & 20 & 12 & 44 & 92 & 5.0715 & 3.5085 & 83.49 \\
\hline 19 & 20 & 12 & 44 & 92 & 5.2075 & 3.6153 & 86.03 \\
\hline 20 & 20 & 12 & 44 & 93 & 5.3445 & 3.7229 & 88.59 \\
\hline 21 & 20 & 12 & 44 & 93 & 5.4815 & 3.8305 & 91.15 \\
\hline 22 & 20 & 12 & 44 & 93 & 5.6185 & 3.9381 & 93.71 \\
\hline 23 & 17 & 16 & 49 & 93 & 5.7555 & 4.0477 & 81.87 \\
\hline 24 & & & & $80.5^{4}$ & & & \\
\hline Total & & & & & & & 1506.8 \\
\hline
\end{tabular}

${ }^{1} \pm 1$ mil for all plates

${ }^{2} \pm 11 \%$ in plate $1 ; \pm 8.3 \%$ in plate $2 ; \pm 6.3 \%$ in plate $3 ; \pm 5.0 \%$ in plates $4-22 ; \pm 5.9 \%$ in plate 23

${ }^{2}$ Plate 1 to outer edge of inner roller

${ }^{4}$ Plate 23 to outer edge of outer roller
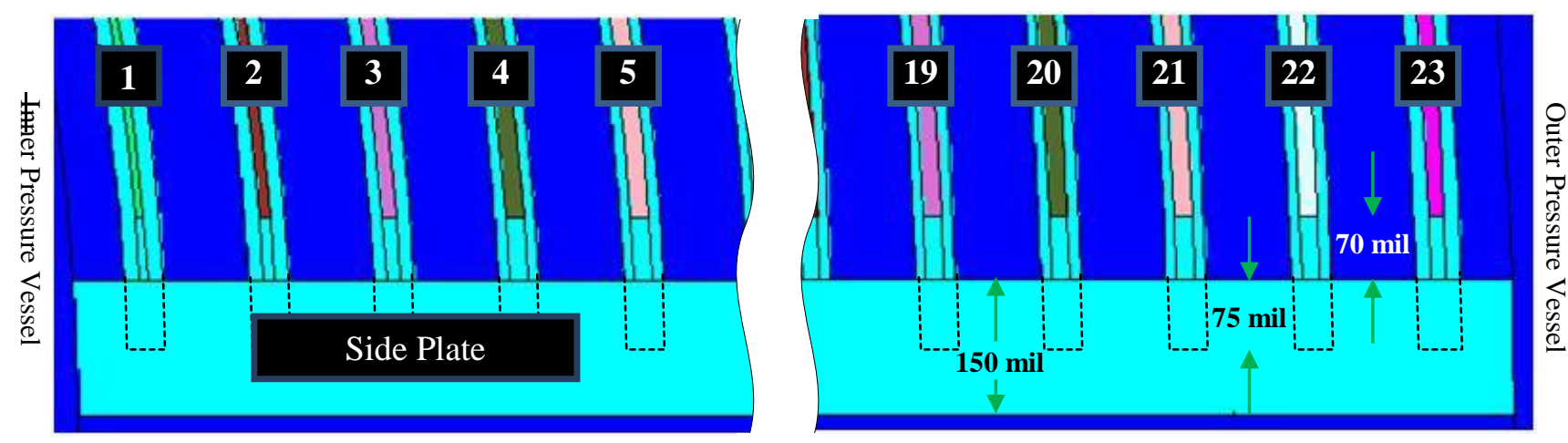

Figure 2.4. Cross Section View of MURR LEU Element Plates 1-5 and 19-23. 


\subsection{Element Design Parameters and Tolerances}

Table 2.2 summarizes fuel design and performance parameters, and associated tolerances, for the current HEU and the proposed LEU fuel elements for MURR. Figure 2.5 provides a cross sectional illustration of an LEU fuel plate with the fuel meat, $\mathrm{Zr}$ interlayer, and Al-6061 clad tolerances noted.

The data in Table 2.2 are derived from the Preliminary Safety Analysis Report [4] for MURR with modifications that reflect the LEU element design described in detail in Reference 1. The fuel design, measurement uncertainties, and fabrication tolerances are crucial parameters for the performance and safety analyses. For each parameter, the table provides the HEU fuel specification, the corresponding value assumed or required for the LEU analysis, the relevant GTRI pillar, and the portion of the Safety Analysis Report (SAR) impacted by the data.

Additionally, flow testing of the LEU fuel plates, which are thinner and have a different fuel meat/core than the HEU fuel plates, is needed to ensure mechanical stability in the MURR thermal-hydraulic environment.

Another parameter of interest is the fission product release fractions from the monolithic U-Mo LEU fuel. The metallic matrix differs from the $\mathrm{U}-\mathrm{Al}_{\mathrm{x}}$ matrix of the HEU fuel. Hence, the fission product retention characteristics during a Maximum Hypothetical Accident (MHA) will vary to some degree relative to the current $\mathrm{U}-\mathrm{Al}_{\mathrm{x}}$ dispersion fuel. Although there is no assumption of fission product retention of $\mathrm{I}, \mathrm{Kr}$, or Xe in the MURR MHA analysis, a confirmatory experiment is requested to evaluate if the assumption of complete release of $\mathrm{I}, \mathrm{Kr}$, and $\mathrm{Xe}$ from a melt is overly conservative. Additionally, any release of actinides from the LEU fuel should also be assessed and appropriately included in the consequences of the MHA and/or the mishandling or malfunction of fuel accident scenarios. 
ANL/RERTR/TM-13-1

Revision 1

Table 2.2. Summary of Element Design Parameters and Tolerances.

\begin{tabular}{|c|c|c|c|c|}
\hline Parameter & HEU Specification & $\begin{array}{c}\text { LEU Analysis } \\
\text { Assumes/Requires }\end{array}$ & $\begin{array}{l}\text { GTRI } \\
\text { Pillar } \\
\end{array}$ & Required for SAR Analysis \\
\hline $\begin{array}{l}\text { Coolant Channel } 1 \\
\begin{array}{l}\text { From Plate } 1 \text { to bounding edge of inner } \\
\text { rollers }\end{array} \\
\text { From Plate } 1 \text { to Inner Pressure Vessel Wall }\end{array}$ & $95 \pm 7$ mil & $\begin{array}{c}80.5 \pm 7 \text { mil } \\
\text { (Tolerance is under } \\
\text { investigation) }\end{array}$ & $\mathrm{FFC}$ & $\begin{array}{c}\text { Thermal-hydraulic }(\mathrm{T}-\mathrm{H}) \text { Hot } \\
\text { Channel Factors (HCF); } \\
\text { Transients; Verify that channel } 1 \\
\text { is not limiting channel }\end{array}$ \\
\hline Coolant Channel 2-5 & $80 \mathrm{mil} \pm 8 \mathrm{mil}$ & $93 \mathrm{mil} \pm 8 \mathrm{mil}$ & FFC & $\begin{array}{c}\text { T-H HCF; Transients; Determine } \\
\text { limiting channel }\end{array}$ \\
\hline Coolant Channel 6-19 & $80 \mathrm{mil} \pm 8 \mathrm{mil}$ & $92 \mathrm{mil} \pm 8 \mathrm{mil}$ & FFC & \\
\hline $\begin{array}{l}\text { Coolant Channel 20-24 (HEU) } \\
\text { Coolant Channel 20-23 (LEU) }\end{array}$ & $80 \mathrm{mil} \pm 8 \mathrm{mil}$ & $93 \mathrm{mil} \pm 8 \mathrm{mil}$ & FFC & \\
\hline $\begin{array}{l}\text { Coolant Channel 25(HEU) } \\
\text { Coolant Channel } 24 \text { (LEU) } \\
\text { From Plate } 24 \text { (HEU), or Plate } 23 \text { (LEU), to } \\
\text { bounding edge of outer rollers } \\
\text {------- } \\
\text { From Plate } 24 \text { (HEU), or Plate } 23 \text { (LEU), to } \\
\text { Outer Pressure Vessel }\end{array}$ & $\begin{array}{l}75 \pm 10 \mathrm{mil} \\
65-122.5\end{array}$ & $\begin{array}{c}80.5 \pm 10 \text { mil } \\
\text { (Tolerance is under } \\
\text { investigation) }\end{array}$ & FFC & $\begin{array}{l}\text { T-H HCF; Transients; Verify that } \\
\text { channel } 25 \text { is not limiting channel }\end{array}$ \\
\hline Clad Thickness & $15 \mathrm{mil} \pm 3 \mathrm{mil}$ & $\begin{array}{c}\text { Plate } 1: 17.5 \mathrm{mil} \\
\text { Plate } 2: 16 \mathrm{mil} \\
\text { Plate } 3: 14 \mathrm{mil} \\
\text { Plate } 4-22: 12 \mathrm{mil} \\
\text { Plate } 23: 16 \mathrm{mil} \\
\text { Note: above clad thickness } \\
\text { includes Zr inter-layer } \\
\text { Tolerance: } \\
\mathrm{Al}: \pm 1 \mathrm{mil} \\
\mathrm{Zr}: \pm 0.5 \mathrm{mil}\end{array}$ & FFC & $\begin{array}{l}\text { Fuel acceptance; } \\
\text { Nuclear design; Determine what } \\
\text { QA checks in fuel fabrication will } \\
\text { verify parameter is within limits }\end{array}$ \\
\hline
\end{tabular}


ANL/RERTR/TM-13-1

Revision 1

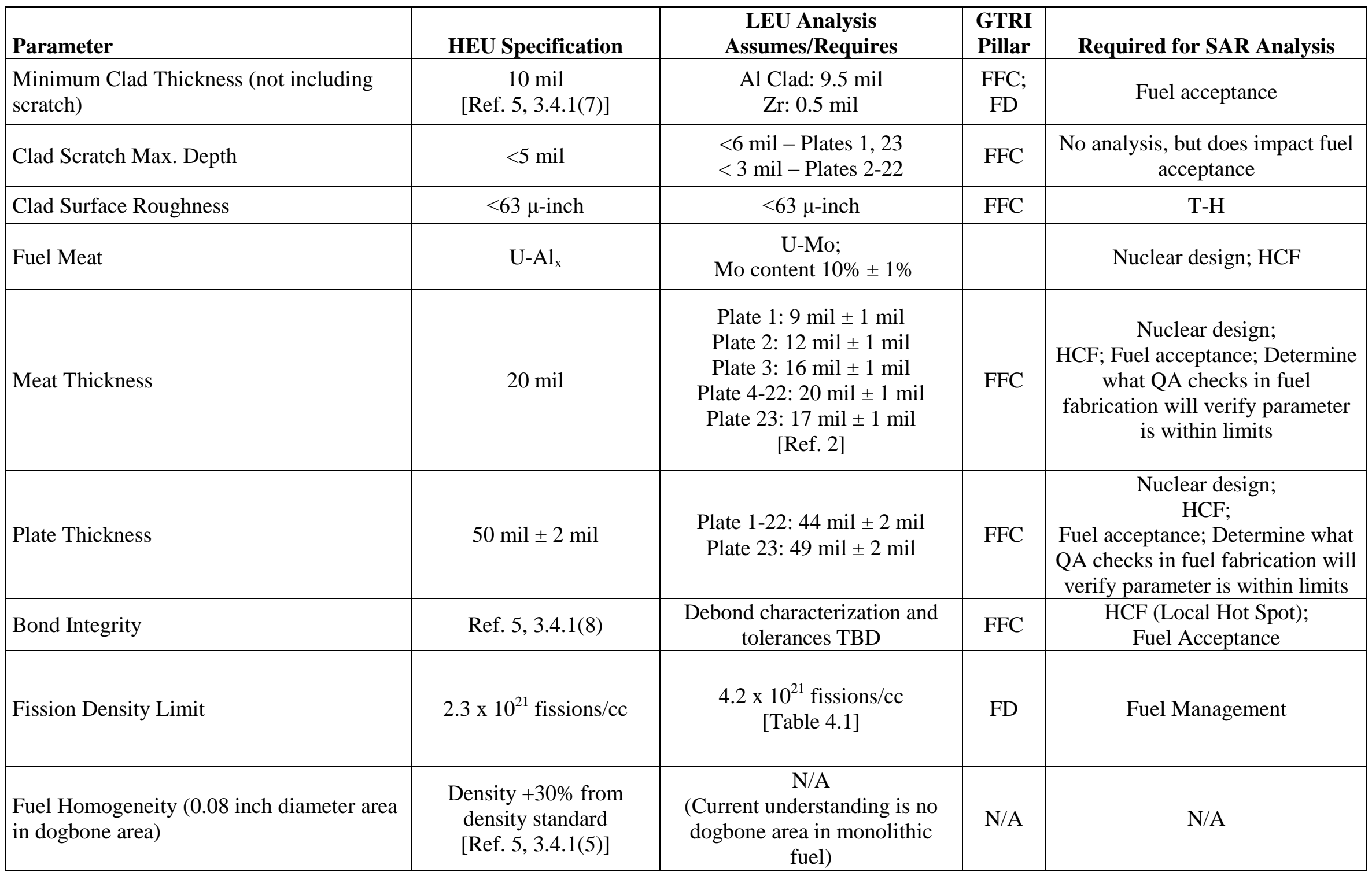


ANL/RERTR/TM-13-1

Revision 1

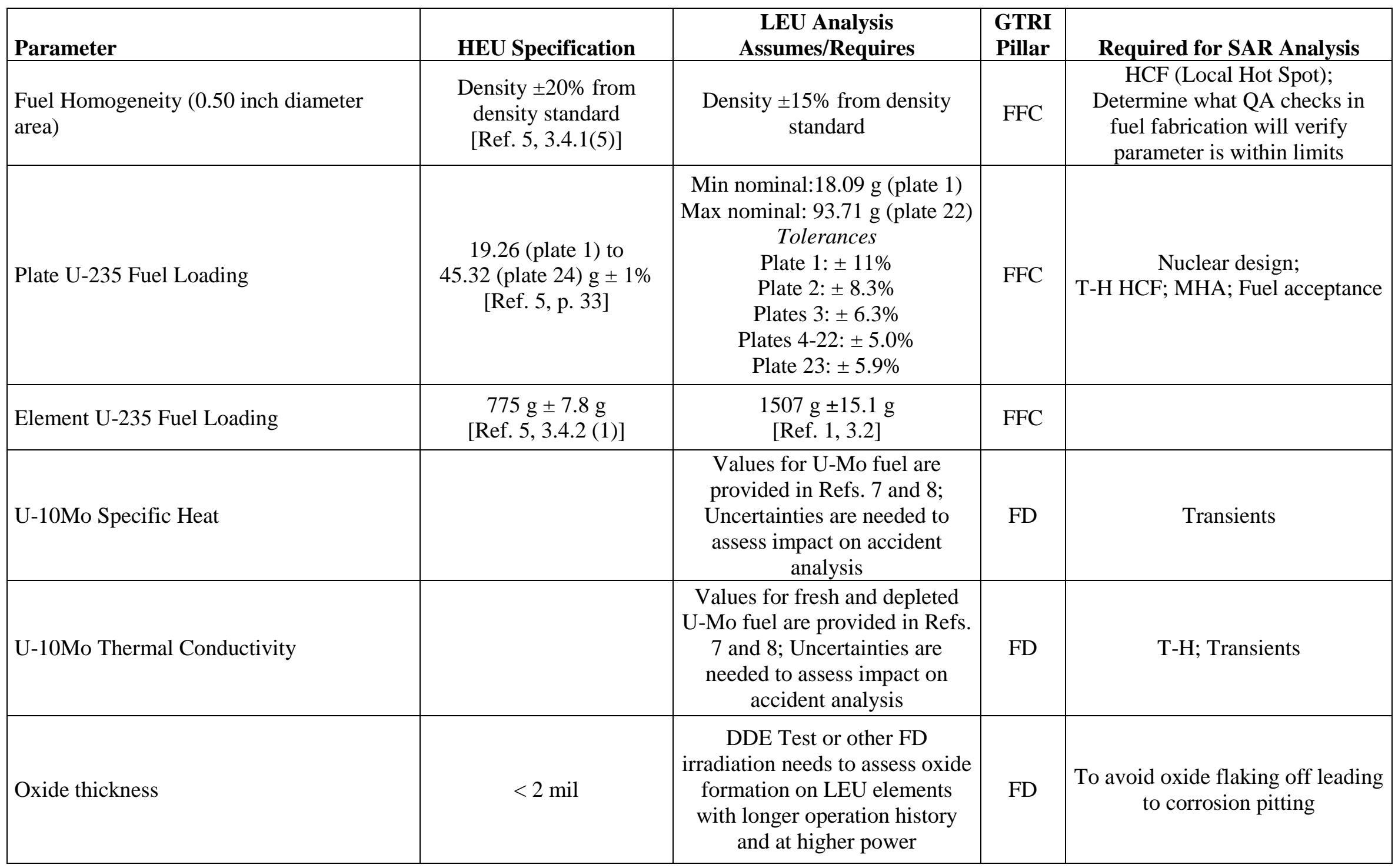

* The end channel thicknesses from the fuel plate surface to the adjacent pressure vessel wall depend on the position of the element between the inner and outer walls of the pressure vessel. The radial distance between the pressure vessel walls is $30 \pm 13.5$ mils greater than the annular thickness of the element envelope. See Figure 2 and Table 2 of Reference 2. 


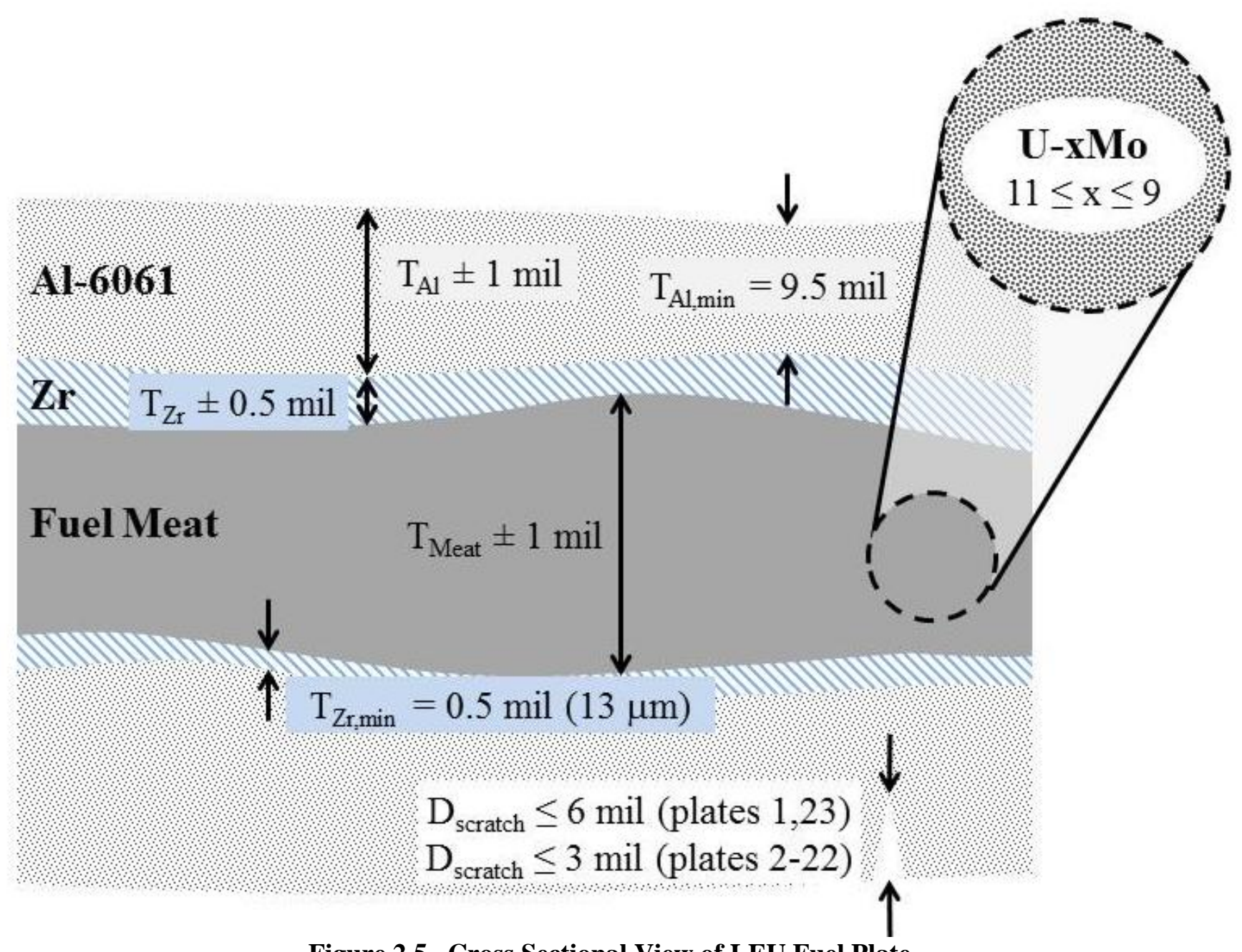

Figure 2.5. Cross Sectional View of LEU Fuel Plate. 


\subsection{LEU OPERATIONS DATA}

The MURR is currently licensed for a maximum steady-state power level of $10 \mathrm{MW}$. This power level provides neutron flux levels in the center flux trap and irradiation positions in the graphite reflector that enable MURR to fulfill its mission of providing experimental and irradiation services to a variety of users.

The goal of the conversion to LEU fuel is to develop a fuel element design that will ensure safe reactor operations, as well as maintaining existing performance. The LEU fuel was designed according to a set of manufacturing assumptions that were provided by the FD and FFC pillars of the RERTR program to reliably manufacture the fuel plates. However, it was found in Reference 1 that a power uprate to $12 \mathrm{MW}$ will be needed for the LEU fueled core to continue to meet the facility's mission. A detailed thermalhydraulics analysis was performed to establish the steady-state safety basis of the proposed LEU fuel and power uprate [2].

To ensure that there is a proper understanding of the basis of the results presented in previous work and here, clarification of the power normalization employed in the analysis is in order. The calculated heat flux profiles presented in Reference 1 are based on $\mathrm{f} 7$ tallies in MCNP, which assume all heat resulting from fission is deposited at the site of the fission event (i.e., in the fuel meat). Furthermore, the results in Reference 1 assumed a core power level of $12 \mathrm{MW}$ (core includes the fuel plates and associated coolant). That is, the contribution of heating in the beryllium reflector and other ex-core components to the total reactor plant power was neglected in the power normalization.

Analysts at MURR calculated that for the LEU-fueled core the fraction of the plant power generated in ex-core structures is $3.6 \%$ of the total [9]. Consequently, for the results presented here, the heat flux and heat generation rate profiles have been normalized to a core power level of $11.57 \mathrm{MW}$, or $96.4 \%$ of a total plant power of $12 \mathrm{MW}$. It should be noted that for the thermal-hydraulic safety basis (Reference 2), heating in all ex-core components was taken into account by decreasing the calculated fuel plate heat flux values in Reference 1 by $3.6 \%$. Lastly, there was no adjustment to the plate heat flux or heat generation rate to account for fission heat deposited directly in the coolant (in other words, the same assumptions as made for the 77 tallies) in either References 1 or 2 , or here.

Calculated results for the fission density were also presented in Reference 1 . These were derived from REBUS-DIF3D depletion modeling, which was based on a power normalization to a total plant power of $12 \mathrm{MW}$. In other words, heat generation in the ex-core components (reflectors, pool, pressure vessels, flux trap) is included in the power normalization in the REBUS-DIF3D calculations. Consequently, the fission rate and fission density calculated by the REBUS-DIF3D model are properly normalized for the LEU-fueled MURR operating at the anticipated uprated power of $12 \mathrm{MW}$. As such, no renormalization of the results presented in Reference 1 is needed.

\subsection{Scope of Steady-State Core Conditions Evaluated}

Power peaking in MURR is dependent upon the mix of burnup states among the elements in the core, upon the core xenon buildup state, upon critical control blade compositions and positions, and upon the experiment/sample loadings, particularly in the flux trap. Twenty-four cores loaded with the proposed LEU fuel design that covered the range of expected variations in these conditions were examined. In the results presented on the following pages, cases are labeled with a nomenclature $c f b$, where $c$ indicates the fuel burnup and xenon condition, $f$ indicates the flux trap loading, and $b$ indicates the control blade conditions. The nomenclature of the core labels is defined in Table 3.1. The derivation of each of the components of the core state is described below. A summary of the MCNP cases for these twenty-four cores is provided in Table 3.2 . 
Table 3.1. Nomenclature for LEU Core Case Names: $c f b$ (e.g. 5B1)

\begin{tabular}{|l|l|}
\hline$c=5$ & All CD35 elements fresh, BOC (no Xe) \\
\hline$c=6$ & All CD35 elements fresh, day 2 (eq. Xe) \\
\hline$c=7$ & Reference mixed CD35 core, BOC (no Xe) \\
\hline$c=8$ & Reference mixed CD35 core, day 2 (eq. Xe) \\
\hline $\begin{array}{l}\mid l \\
f=\mathrm{A}\end{array}$ & Flux trap holder with typical samples loaded in center test hole \\
\hline$f=\mathrm{B}$ & No flux trap holder or samples loaded in center test hole - only water \\
\hline$b=n u l l$ & All blades fresh and banked. \\
\hline$b=1$ & $\begin{array}{l}\text { Blades C and D at 8 years depletion, blades A and B fresh. Blades C and D } \\
\text { positioned 1 inch higher than A and B, per Technical Specification limit. }\end{array}$ \\
\hline$b=2$ & $\begin{array}{l}\text { Blades A and D at 8 years depletion, blades B and C fresh. Blades A and D } \\
\text { positioned 1 inch higher than B and C, per Technical Specification limit. }\end{array}$ \\
\hline
\end{tabular}

Core burnup state. The MURR operates continuously with the exception of a weekly scheduled shutdown. Over the past 35 years of operation, the MURR has averaged approximately 6.3 days/week at full power. The weekly shutdown provides an opportunity to access samples in the center test hole, to perform surveillance tests and maintenance, and to replace all eight fuel elements in the core. Replacing the fuel elements provides a xenon free core for restart and the chance to remix or shuffle the elements that will be used in the core. The active fuel cycle typically consists of 32 fuel elements; corresponding to sixteen pairs of elements. A core loading will always consist of four different pairs of elements, with the two elements of each pair loaded opposite of each other in the core (e.g., positions 1 and 5 in Figure 2.1 are paired together).

A fuel cycle simulation of the complex MURR fuel shuffling sequence for typical ("pseudo-equilibrium") reference mixed burnup cores was performed with REBUS-DIF3D. Elements are loaded in the core about 19 times before discharge from the fuel cycle. This is the same number of times the HEU fuel is typically loaded in the MURR before discharge from the fuel cycle. While the core residence time is the same for both the LEU and HEU fuel, the discharge burnup of the LEU elements is $20 \%$ greater (about $180 \mathrm{MWd}$ ) due to the higher core operating power level. An MCNP model of a chosen reference mixedburnup core was used to evaluate experimental performance, calculate reactivity parameters, and calculate the detailed power distributions needed for the steady-state thermal-hydraulics analyses. The fuel compositions for the MCNP analyses were derived from the REBUS-DIF3D results.

Table 3.3 below summarizes the anticipated burnup ranges of LEU elements in the eight core positions of MURR, as well as the burnups of the elements at the beginning-of-cycle (BOC) for the selected reference mixed-burnup core. Note that cores with eight fresh elements were also evaluated, but these will only be loaded for startup testing of the converted core.

Flux trap conditions. Two flux trap, or center test hole, conditions were considered. The nominal case, indicated by $f=\mathrm{A}$ in the case name label, has the flux trap holder loaded with typical samples for MURR operations. An off-nominal "empty center test hole" case, in which the flux trap holder is not inserted and only pool water is in the center test hole, is indicated by $f=B$. In all cases, the irradiation positions in the graphite reflector were modeled with typical samples for those locations. 
Table 3.2. Summary of Power Distribution Evaluations for LEU Cores.

\begin{tabular}{|c|c|c|c|c|c|c|c|c|c|c|c|c|c|}
\hline \multicolumn{4}{|c|}{$\begin{array}{l}\text { Core state that may bound power } \\
\text { peaking }\end{array}$} & \multicolumn{4}{|c|}{$\begin{array}{l}\text { Element Burnup (MWd) } \\
\text { at Beginning of Week }\end{array}$} & \multirow[b]{2}{*}{$\begin{array}{l}\text { Fresh } \\
\text { Blades }\end{array}$} & \multirow[b]{2}{*}{$\begin{array}{l}\text { Depleted } \\
\text { Blades }\end{array}$} & \multicolumn{3}{|c|}{$\begin{array}{l}\text { Critical Blade Position } \\
\text { (Inches withdrawn) }\end{array}$} & \multirow[b]{2}{*}{$\begin{array}{l}\text { MCNP } \\
\text { k-eff }\end{array}$} \\
\hline Case & $\begin{array}{l}\text { Burnup } \\
\text { State }\end{array}$ & $\begin{array}{l}\text { Time } \\
\text { (Days) }\end{array}$ & $\begin{array}{l}\text { Flux } \\
\text { Trap }\end{array}$ & $\begin{array}{l}\mathrm{X} 1 \\
\mathrm{X} 5\end{array}$ & $\begin{array}{l}\mathrm{X} 2 \\
\mathrm{X} 6\end{array}$ & $\begin{array}{l}\mathrm{X} 3 \\
\mathrm{X} 7\end{array}$ & $\begin{array}{l}\mathrm{X} 4 \\
\mathrm{X} 8\end{array}$ & & & $\begin{array}{c}\text { Fresh } \\
\text { Blades }\end{array}$ & $\begin{array}{c}\text { Depleted } \\
\text { Blades }\end{array}$ & $\begin{array}{c}\text { Reg } \\
\text { Blade }\end{array}$ & \\
\hline $5 \mathrm{~A}$ & Fresh & 0 & Samples & 0 & 0 & 0 & 0 & $\mathrm{~A}, \mathrm{~B}, \mathrm{C}, \mathrm{D}$ & & 13.259 & & 10 & 1.00016 \\
\hline $5 \mathrm{~A} 1$ & Fresh & 0 & Samples & 0 & 0 & 0 & 0 & $A, B$ & $\mathrm{C}, \mathrm{D}$ & 10.656 & 11.656 & 10 & 0.99993 \\
\hline $5 \mathrm{~A} 2$ & Fresh & 0 & Samples & 0 & 0 & 0 & 0 & $\mathrm{~B}, \mathrm{C}$ & $A, D$ & 10.814 & 11.814 & 10 & 0.99999 \\
\hline $6 \mathrm{~A}$ & Fresh & 2 & Samples & 0 & 0 & 0 & 0 & $\mathrm{~A}, \mathrm{~B}, \mathrm{C}, \mathrm{D}$ & & 17.193 & & 15 & 0.99985 \\
\hline $6 \mathrm{~A} 1$ & Fresh & 2 & Samples & 0 & 0 & 0 & 0 & $A, B$ & $\mathrm{C}, \mathrm{D}$ & 14.912 & 15.912 & 15 & 1.00001 \\
\hline $6 \mathrm{~A} 2$ & Fresh & 2 & Samples & 0 & 0 & 0 & 0 & $\mathrm{~B}, \mathrm{C}$ & $\mathrm{A}, \mathrm{D}$ & 15.027 & 16.027 & 15 & 0.99990 \\
\hline $7 \mathrm{~A}$ & "Week 76" & 0 & Samples & 0 & 96 & 77 & 170 & $\mathrm{~A}, \mathrm{~B}, \mathrm{C}, \mathrm{D}$ & & 17.567 & & 10 & 1.00008 \\
\hline 7A1 & "Week 76" & 0 & Samples & 0 & 96 & 77 & 170 & A, B & $\mathrm{C}, \mathrm{D}$ & 15.209 & 16.209 & 10 & 0.99975 \\
\hline $7 \mathrm{~A} 2$ & "Week 76" & 0 & Samples & 0 & 96 & 77 & 170 & $\mathrm{~B}, \mathrm{C}$ & $\mathrm{A}, \mathrm{D}$ & 15.351 & 16.351 & 10 & 1.00014 \\
\hline $8 \mathrm{~A}$ & "Week 76" & 2 & Samples & 0 & 96 & 77 & 170 & $\mathrm{~A}, \mathrm{~B}, \mathrm{C}, \mathrm{D}$ & & 24.314 & & 15 & 1.00001 \\
\hline 8A1 & "Week 76" & 2 & Samples & 0 & 96 & 77 & 170 & A, B & C, D & 22.765 & 23.765 & 15 & 1.00004 \\
\hline $8 \mathrm{~A} 2$ & "Week 76" & 2 & Samples & 0 & 96 & 77 & 170 & $\mathrm{~B}, \mathrm{C}$ & $\mathrm{A}, \mathrm{D}$ & 22.698 & 23.698 & 15 & 0.99986 \\
\hline $5 B$ & Fresh & 0 & Empty & 0 & 0 & 0 & 0 & $\mathrm{~A}, \mathrm{~B}, \mathrm{C}, \mathrm{D}$ & & 13.650 & & 10 & 0.99998 \\
\hline $5 B 1$ & Fresh & 0 & Empty & 0 & 0 & 0 & 0 & $A, B$ & $\mathrm{C}, \mathrm{D}$ & 11.080 & 12.080 & 10 & 1.00003 \\
\hline $5 \mathrm{~B} 2$ & Fresh & 0 & Empty & 0 & 0 & 0 & 0 & $\mathrm{~B}, \mathrm{C}$ & $\mathrm{A}, \mathrm{D}$ & 11.258 & 12.258 & 10 & 1.00009 \\
\hline $6 \mathrm{~B}$ & Fresh & 2 & Empty & 0 & 0 & 0 & 0 & $\mathrm{~A}, \mathrm{~B}, \mathrm{C}, \mathrm{D}$ & & 17.891 & & 15 & 0.99997 \\
\hline $6 \mathrm{~B} 1$ & Fresh & 2 & Empty & 0 & 0 & 0 & 0 & A, B & $\mathrm{C}, \mathrm{D}$ & 15.580 & 16.580 & 15 & 0.99988 \\
\hline $6 \mathrm{~B} 2$ & Fresh & 2 & Empty & 0 & 0 & 0 & 0 & $\mathrm{~B}, \mathrm{C}$ & $\mathrm{A}, \mathrm{D}$ & 15.741 & 16.741 & 15 & 1.00017 \\
\hline $7 B$ & "Week 76" & 0 & Empty & 0 & 96 & 77 & 170 & $\mathrm{~A}, \mathrm{~B}, \mathrm{C}, \mathrm{D}$ & & 18.193 & & 10 & 1.00013 \\
\hline 7B1 & "Week 76" & 0 & Empty & 0 & 96 & 77 & 170 & $\mathrm{~A}, \mathrm{~B}$ & $\mathrm{C}, \mathrm{D}$ & 15.933 & 16.933 & 10 & 1.00012 \\
\hline 7B2 & "Week 76" & 0 & Empty & 0 & 96 & 77 & 170 & $\mathrm{~B}, \mathrm{C}$ & $\mathrm{A}, \mathrm{D}$ & 16.030 & 17.030 & 10 & 1.00003 \\
\hline $8 B$ & "Week 76" & 2 & Empty & 0 & 96 & 77 & 170 & $\mathrm{~A}, \mathrm{~B}, \mathrm{C}, \mathrm{D}$ & & 26.000 & & 15 & 0.99917 \\
\hline $8 B 1$ & "Week 76" & 2 & Empty & 0 & 96 & 77 & 170 & A, B & C, D & 25.621 & 26.000 & 15 & 0.99998 \\
\hline $8 B 2$ & "Week 76" & 2 & Empty & 0 & 96 & 77 & 170 & $\mathrm{~B}, \mathrm{C}$ & $\mathrm{A}, \mathrm{D}$ & 25.312 & 26.000 & 15 & 0.99986 \\
\hline
\end{tabular}

"Samples" indicates a typical loading of samples in all three flux trap tubes.

"Empty" indicates neither samples nor tubes in the flux trap (i.e., "empty island" configuration).

Full blade withdrawal is 26 inches. 
Table 3.3. Beginning-of-Cycle Burnups for Reference LEU Mixed Burnup Core $(c=7,8)$.

\begin{tabular}{|c|c|c|}
\hline Core Positions & $\begin{array}{c}\text { Typical BOC Burnup Range } \\
\text { (MWd) }^{\mathbf{1}}\end{array}$ & $\begin{array}{c}\text { Reference Core BOC Burnup } \\
\text { (MWd) }\end{array}$ \\
\hline X1 and X5 & 0 to $50(20$ avg.) & 0 \\
\hline X3 and X7 & 40 to $90(64$ avg. $)$ & 77 \\
\hline X2 and X6 & 85 to $135(108$ avg.) & 96 \\
\hline X4 and X8 & 125 to $170(153$ avg. $)$ & 170 \\
\hline
\end{tabular}

${ }^{1}$ Burnup values from fuel cycle simulation in REBUS-DIF3D

Control blade conditions. Reactivity control of MURR is accomplished by control blades that move vertically in an annular gap between the outer pressure vessel and a beryllium reflector (see Figure 2.1). The blades control the reactivity by varying neutron reflection from the beryllium reflector. There are four shim control blades constructed of BORAL ${ }^{\circledR}$, and one is a stainless steel regulating blade.

Within the first two days of the one week cycle, the control blades move from a typical position of 17 inches withdrawn at BOC to 23 inches withdrawn after xenon builds in. This affects the axial shape of the neutron flux and power peaking. Furthermore, while the control blades are typically banked, the MURR Technical Specifications allow for the blade tips to differ in height relative to one another by up to one inch. This blade height mismatch can cause a tilting of the neutron flux shape. Lastly, the BORAL ${ }^{\circledR}$ material depletes significantly in the region near the blade tip, which is in a position of higher neutron fluence. Additionally, the MURR control blades are shuffled in a multi-year scheme analogous to fuel shuffling, resulting in blades with differing boron concentrations that affects the axial flux shape. Blades are inserted for a two year cycle and typically average about 4 years of use before being retired, but can be used for as long as 10 years. Thus, when calculating the detailed power distributions, the effects of shim blade depletion and mismatch of the shim blade heights relative to one another were evaluated.

\subsection{Axial and Azimuthal Discretization of the Results}

In the detailed power distribution tallies compiled with MCNP, the fuel meat in each plate was divided into 24 one-inch axial segments. While the power distribution varies most significantly in the axial and radial (plate-by-plate) dimensions, it also varies along the width of the fuel meat, and can peak sharply at the edge of the fuelled section of the plate due to an increase in the local water-to-fuel ratio near the edge of the fuel meat. 3-D computational fluid dynamics (CFD) analyses were performed to determine the proper discretization of the fuel plates in the azimuthal dimension [10]. From this analysis, it was concluded that the MCNP power distributions should be tallied by azimuthally subdividing the meat of each fuel plate into nine tally stripes; three stripes of $5 \mathrm{~mm}$ each along both edges of the fuel meat, and three stripes of equal angle in the middle of the plate to cover the balance of the plate.

\subsection{Limiting Steady-State Conditions}

Table 3.4 summarizes the key hot-stripe and local heating rates for the set of twenty-four cores examined in the steady-state neutronics analysis. The heat flux values reported in this table assume that the fraction of heat generated in the fuel plate goes out evenly from the left and right surfaces of the plate. The hotstripe heat flux is an axially-averaged heat flux for a given azimuthal stripe, and is the largest in core 8A2 of all cases examined. This parameter influences the margin to the onset of flow instability (FI) in steadystate thermal-hydraulic analysis. However, for the purpose of planning and evaluating irradiation experiments, the peak local heat flux expected under steady-state conditions is of interest. The greatest value for this parameter among the cases examined is observed for core 5B1, which is a core loaded with all fresh LEU elements at BOC, an empty flux trap, and the control blades in a skewed position (refer to 
Table 3.4. Summary of Key Hot-Stripe and Local Heating Rates Evaluated for LEU Cores.

\begin{tabular}{|c|c|c|c|c|c|c|}
\hline \multirow[b]{2}{*}{ Core } & \multicolumn{2}{|c|}{$\begin{array}{c}\text { Hot Stripe Heat Flux } \\
\left(\mathrm{W} / \mathrm{cm}^{2}\right)\end{array}$} & \multicolumn{2}{|c|}{$\begin{array}{c}\text { Local Heat Flux } \\
\left(\mathrm{W} / \mathrm{cm}^{2}\right)\end{array}$} & \multicolumn{2}{|c|}{$\begin{array}{c}\text { Local Power Density } \\
\left(\mathrm{W} / \mathrm{cm}^{\mathbf{3}}\right)\end{array}$} \\
\hline & Peak & Location $^{1}$ & Peak & Location $^{2}$ & Peak & Location $^{2}$ \\
\hline $5 \mathrm{~A}$ & 120.8 & X5 P04 S1 & 214.2 & X8 P23 S9 A17 & $14,374.0$ & X3 P01 S1 A17 \\
\hline $5 \mathrm{~A} 1$ & 124.9 & X8 P04 S1 & 224.9 & X7 P23 S1 A17 & $14,719.0$ & X7 P01 S9 A16 \\
\hline $5 \mathrm{~A} 2$ & 125.1 & X1 P04 S9 & 221.2 & X1 P23 S9 A17 & $14,600.6$ & X2 P01 S9 A16 \\
\hline $6 \mathrm{~A}$ & 121.3 & X7 P23 S1 & 204.3 & X8 P23 S9 A15 & $13,772.2$ & X4 P01 S9 A14 \\
\hline $6 \mathrm{~A} 1$ & 137.9 & X6 P23 S9 & 214.2 & X6 P23 S9 A15 & $13,680.2$ & X8 P01 S1 A15 \\
\hline $6 \mathrm{~A} 2$ & 135.9 & X8 P23 S9 & 208.6 & X8 P23 S9 A15 & $13,574.7$ & X2 P01 S9 A14 \\
\hline $7 \mathrm{~A}$ & 126.0 & X1 P23 S1 & 203.2 & X1 P23 S1 A16 & $14,400.2$ & X5 P01 S1 A15 \\
\hline 7A1 & 137.0 & X1 P23 S1 & 219.9 & X1 P23 S1 A15 & $14,190.8$ & X5 P01 S9 A14 \\
\hline 7A2 & 142.8 & X1 P23 S1 & 210.2 & X1 P23 S9 A17 & $14,075.1$ & X1 P01 S9 A15 \\
\hline $8 \mathrm{~A}$ & 143.6 & X1 P23 S1 & 186.1 & X1 P23 S1 A14 & $12,780.0$ & X5 P01 S1 A12 \\
\hline $8 \mathrm{~A} 1$ & 149.4 & X1 P23 S1 & 194.6 & X1 P23 S1 A14 & $12,709.3$ & X1 P01 S1 A12 \\
\hline $8 \mathrm{~A} 2$ & 151.1 & X1 P23 S1 & 189.6 & X1 P23 S1 A11 & $12,583.3$ & X5 P01 S1 A14 \\
\hline $5 \mathrm{~B}$ & 129.0 & X7 P04 S1 & 212.4 & X8 P23 S9 A17 & $15,414.5$ & X2 P01 S9 A17 \\
\hline $5 \mathrm{~B} 1$ & 127.4 & X8 P04 S9 & 225.6 & X6 P23 S9 A16 & $15,825.9$ & X7 P01 S1 A16 \\
\hline $5 \mathrm{~B} 2$ & 122.2 & X5 P04 S9 & 221.6 & X8 P23 S9 A17 & $15,438.5$ & X1 P01 S1 A16 \\
\hline $6 \mathrm{~B}$ & 122.6 & X6 P23 S9 & 202.6 & X6 P23 S9 A15 & $14,617.4$ & X1 P01 S1 A15 \\
\hline $6 \mathrm{~B} 1$ & 138.8 & X7 P23 S1 & 209.4 & X7 P23 S1 A13 & $14,187.4$ & X7 P01 S9 A14 \\
\hline $6 \mathrm{~B} 2$ & 137.0 & X8 P23 S9 & 205.8 & X8 P23 S9 A14 & $14,170.7$ & X8 P01 S9 A15 \\
\hline $7 \mathrm{~B}$ & 128.3 & X1 P23 S1 & 201.4 & X1 P23 S1 A15 & $14,646.7$ & X5 P01 S1 A14 \\
\hline 7B1 & 138.9 & X1 P23 S1 & 218.2 & X1 P23 S1 A15 & $14,762.2$ & X5 P01 S1 A15 \\
\hline 7B2 & 144.6 & X1 P23 S1 & 209.2 & X1 P23 S1 A14 & $14,756.8$ & X1 P01 S1 A15 \\
\hline $8 \mathrm{~B}$ & 145.9 & X1 P23 S1 & 183.8 & X1 P23 S1 A13 & $13,039.3$ & X1 P01 S1 A13 \\
\hline $8 B 1$ & 146.9 & X1 P23 S1 & 184.4 & X1 P23 S1 A13 & $12,942.7$ & X1 P01 S1 A10 \\
\hline $8 \mathrm{~B} 2$ & 149.1 & X1 P23 S1 & 184.7 & X1 P23 S1 A10 & $12,814.8$ & X5 P01 S9 A12 \\
\hline
\end{tabular}

${ }^{1} \mathrm{Xi} \mathrm{Pkk} \mathrm{Sj}$. $\mathrm{i}$ is element number. $\mathrm{kk}$ is plate, numbered 1-23 moving from inner pressure vessel to outer pressure vessel. $\mathrm{j}$ is azimuthal stripe in plate, numbered 1-9 moving clockwise, looking from above.

${ }^{2} \mathrm{Xi}$ Pkk Sj Azz. i is element number. kk is plate, numbered 1-23 moving from inner pressure vessel to outer pressure vessel. $\mathrm{j}$ is azimuthal stripe in plate, numbered 1-9 moving clockwise, looking from above. zz is axial level, numbered 1-24 from top of fuel meat.

Table 3.1 above for a description of the control blade pattern). Consequently, the heat flux profile for this particular case will be examined in more detail. It is noted that the set of results for the twenty-four cases examined confirms that the local heat flux is peaked at beginning-of-life for the LEU fueled MURR.

Another parameter of interest for planning and evaluating irradiation experiments is the fission rate density (fissions $/ \mathrm{cm}^{3}$-s) in the fuel foils, which is directly proportional to the local power density calculated with the MCNP f7 tallies. Table 3.4 shows that the greatest local power density also occurs in core 5B1. Table 3.5 compares the calculated peak fission rate density by element for this core, as well as cores 7A and 8A. Cores 7A and 8A will be typical of MURR operations, as they are loaded with a mix of fresh and previously burned elements. The peak fission rate density is $10 \%$ to $20 \%$ lower for these cores compared with core 5B1. 
Table 3.5. Peak Fission Rate Density for Various Cores.

\begin{tabular}{|c|c|c|c|c|c|c|}
\hline \multirow{3}{*}{$\begin{array}{c}\text { Core } \\
\text { Position }\end{array}$} & \multicolumn{3}{|c|}{ Burnup (MWd) } & \multicolumn{3}{|c|}{ Peak Fission Rate Density (fissions $/ \mathrm{cm}^{3}$-s) } \\
\hline & \multicolumn{3}{|c|}{ Core } & \multicolumn{3}{|c|}{ Core } \\
\hline & $7 A$ & $8 A$ & $5 B 1$ & $7 A$ & $8 A$ & $5 B 1$ \\
\hline 1 & 0 & 0 & 0 & $4.5 \mathrm{E}+14$ & $4.0 \mathrm{E}+14$ & $4.8 \mathrm{E}+14$ \\
\hline 2 & 96 & 96 & 0 & $3.7 \mathrm{E}+14$ & $3.3 E+14$ & $4.7 \mathrm{E}+14$ \\
\hline 3 & 77 & 77 & 0 & $3.9 \mathrm{E}+14$ & $3.4 \mathrm{E}+14$ & $4.6 \mathrm{E}+14$ \\
\hline 4 & 170 & 170 & 0 & $3.1 \mathrm{E}+14$ & $2.7 \mathrm{E}+14$ & $4.6 \mathrm{E}+14$ \\
\hline 5 & 0 & 0 & 0 & $4.6 \mathrm{E}+14$ & 4.1E+14 & $4.8 \mathrm{E}+14$ \\
\hline 6 & 96 & 96 & 0 & $3.7 \mathrm{E}+14$ & $3.3 \mathrm{E}+14$ & $5.0 \mathrm{E}+14$ \\
\hline 7 & 77 & 77 & 0 & $3.8 \mathrm{E}+14$ & $3.4 \mathrm{E}+14$ & $5.1 \mathrm{E}+14$ \\
\hline 8 & 170 & 170 & 0 & $3.1 \mathrm{E}+14$ & $2.7 \mathrm{E}+14$ & $4.9 \mathrm{E}+14$ \\
\hline \multicolumn{4}{|c|}{ Location of Peak $^{1}$} & X5 P01 S1 A15 & X5 P01 S1 A12 & X7 P01 S1 A16 \\
\hline
\end{tabular}

${ }^{1}$ Nomenclature for location of peak described in footnote of Table 3.3.

\subsubsection{Heat Flux Profile}

Table 3.6 provides the 2-D heat flux profile (axial and azimuthal) for the plate that has the greatest local heat flux of all the steady-state cores examined. This occurs in core 5B1 for plate 23 in the element in core position 6. A contour plot of the heat flux profile for this plate is shown in Figure 3.1.

Another figure of merit for fuel qualification experiments is the peak fuel meat temperatures that may be expected in the MURR fuel plates during steady-state reactor operations. Detailed calculations of the fuel meat and corresponding clad temperatures for the set of 24 cores examined in the steady-state technical basis were performed and are described in Section 3.3.4. The calculations show that the peak fuel meat temperature occurs in plate 22 of a fuel element near the end of life in core configuration 7A1. Table 3.7 and Figure 3.2 provide the heat flux profile data for this plate.

Since the peak fuel meat temperature occurs in a fuel plate near the end of life, the heat flux profile data in Tables 3.8-3.11 and the corresponding heat flux contour plots in Figures 3.3-3.4 are provided to show the evolution of the heat flux profile in plate 22 of a MURR LEU fuel element over its lifetime. The heat flux data were extracted from MCNP calculations for elements at four different burnup state points in core 7A, which has a mix of fuel elements at burnups that are expected to be typical for the MURR at "pseudo-equilibrium," as well as experimental samples in the flux trap and irradiation materials in the graphite reflector that are typical for weekly MURR operations. The results show that the heat flux in the plate decreases by about $10 \%$ over its lifetime. However, the maximum fuel temperature occurs at endof-life due to the combined effects of burnup-induced swelling in the fuel meat and oxide growth on the plate surface. These phenomena reduce the coolant channel gap and increase the thermal resistance across the clad, which contribute to the temperature peaking. 
Table 3.6. Maximum Heat Flux $\left(W / \mathrm{cm}^{2}\right)$ of All Steady-State Cores:

Fresh LEU Element in Core 5B1, Position X6, No Xe, Plate 23, Empty FT.

\begin{tabular}{|c|c|c|c|c|c|c|c|c|c|}
\hline \multirow{2}{*}{$\begin{array}{c}\text { Axial } \\
\text { position } \\
\text { from top } \\
\text { of fuel } \\
\text { (inches) }\end{array}$} & \multicolumn{2}{|c|}{ Meat width } & 4.048 & \multicolumn{2}{|l|}{ inches } & \multicolumn{2}{|c|}{ Meat thickness } & 17 & mil \\
\hline & $\begin{array}{c}0.000 \text { to } \\
0.197 \\
\text { inches }\end{array}$ & $\begin{array}{c}0.197 \text { to } \\
0.394 \\
\text { inches }\end{array}$ & $\begin{array}{c}0.394 \text { to } \\
0.591 \\
\text { inches }\end{array}$ & $\begin{array}{c}0.591 \text { to } \\
1.546 \\
\text { inches }\end{array}$ & $\begin{array}{c}1.546 \text { to } \\
2.502 \\
\text { inches }\end{array}$ & $\begin{array}{c}2.502 \text { to } \\
3.457 \\
\text { inches }\end{array}$ & $\begin{array}{c}3.457 \text { to } \\
3.654 \\
\text { inches }\end{array}$ & $\begin{array}{c}3.654 \text { to } \\
3.851 \\
\text { inches }\end{array}$ & $\begin{array}{c}3.851 \text { to } \\
4.048 \\
\text { inches }\end{array}$ \\
\hline 0.5 & 16.06 & 15.14 & 14.91 & 14.90 & 14.84 & 15.40 & 15.75 & 16.07 & 17.14 \\
\hline 1.5 & 15.64 & 14.75 & 14.53 & 14.51 & 14.45 & 15.00 & 15.35 & 15.66 & 16.70 \\
\hline 2.5 & 18.43 & 17.38 & 17.12 & 17.10 & 17.03 & 17.68 & 18.08 & 18.45 & 19.68 \\
\hline 3.5 & 22.61 & 21.32 & 21.00 & 20.98 & 20.89 & 21.69 & 22.18 & 22.64 & 24.14 \\
\hline 4.5 & 27.37 & 25.81 & 25.41 & 25.39 & 25.28 & 26.25 & 26.85 & 27.39 & 29.22 \\
\hline 5.5 & 32.41 & 30.56 & 30.09 & 30.06 & 29.94 & 31.08 & 31.79 & 32.44 & 34.60 \\
\hline 6.5 & 36.77 & 34.67 & 34.14 & 34.11 & 33.97 & 35.26 & 36.07 & 36.80 & 39.25 \\
\hline 7.5 & 42.52 & 40.09 & 39.48 & 39.44 & 39.28 & 40.78 & 41.71 & 42.56 & 45.39 \\
\hline 8.5 & 51.93 & 48.97 & 48.23 & 48.18 & 47.98 & 49.81 & 50.94 & 51.98 & 55.44 \\
\hline 9.5 & 82.56 & 77.85 & 76.67 & 76.59 & 76.27 & 79.18 & 80.99 & 82.64 & 88.14 \\
\hline 10.5 & 129.70 & 122.29 & 120.44 & 120.32 & 119.82 & 124.39 & 127.23 & 129.82 & 138.46 \\
\hline 11.5 & 157.85 & 148.84 & 146.58 & 146.43 & 145.83 & 151.39 & 154.84 & 158.00 & 168.51 \\
\hline 12.5 & 172.98 & 163.10 & 160.63 & 160.47 & 159.81 & 165.90 & 169.69 & 173.14 & 184.66 \\
\hline 13.5 & 189.13 & 178.33 & 175.63 & 175.45 & 174.73 & 181.39 & 185.53 & 189.31 & 201.90 \\
\hline 14.5 & 203.88 & 192.24 & 189.33 & 189.14 & 188.36 & 195.54 & 200.00 & 204.08 & 217.65 \\
\hline 15.5 & 211.05 & 199.00 & 195.99 & 195.79 & 194.98 & 202.41 & 207.03 & 211.25 & 225.30 \\
\hline 16.5 & 211.31 & 199.25 & 196.23 & 196.03 & 195.23 & 202.66 & 207.29 & 211.51 & 225.58 \\
\hline 17.5 & 205.02 & 193.32 & 190.39 & 190.20 & 189.42 & 196.63 & 201.12 & 205.22 & 218.87 \\
\hline 18.5 & 197.04 & 185.79 & 182.98 & 182.79 & 182.04 & 188.98 & 193.29 & 197.23 & 210.35 \\
\hline 19.5 & 186.60 & 175.94 & 173.28 & 173.10 & 172.39 & 178.96 & 183.05 & 186.77 & 199.20 \\
\hline 20.5 & 171.45 & 161.66 & 159.21 & 159.05 & 158.40 & 164.43 & 168.18 & 171.61 & 183.03 \\
\hline 21.5 & 155.88 & 146.98 & 144.76 & 144.61 & 144.01 & 149.50 & 152.91 & 156.03 & 166.41 \\
\hline 22.5 & 140.80 & 132.76 & 130.75 & 130.62 & 130.08 & 135.04 & 138.12 & 140.93 & 150.31 \\
\hline 23.5 & 146.46 & 138.09 & 136.00 & 135.87 & 135.31 & 140.46 & 143.67 & 146.60 & 156.35 \\
\hline Ax. Avg. & 117.73 & 111.00 & 109.32 & 109.21 & 108.76 & 112.91 & 115.49 & 117.84 & 125.68 \\
\hline
\end{tabular}




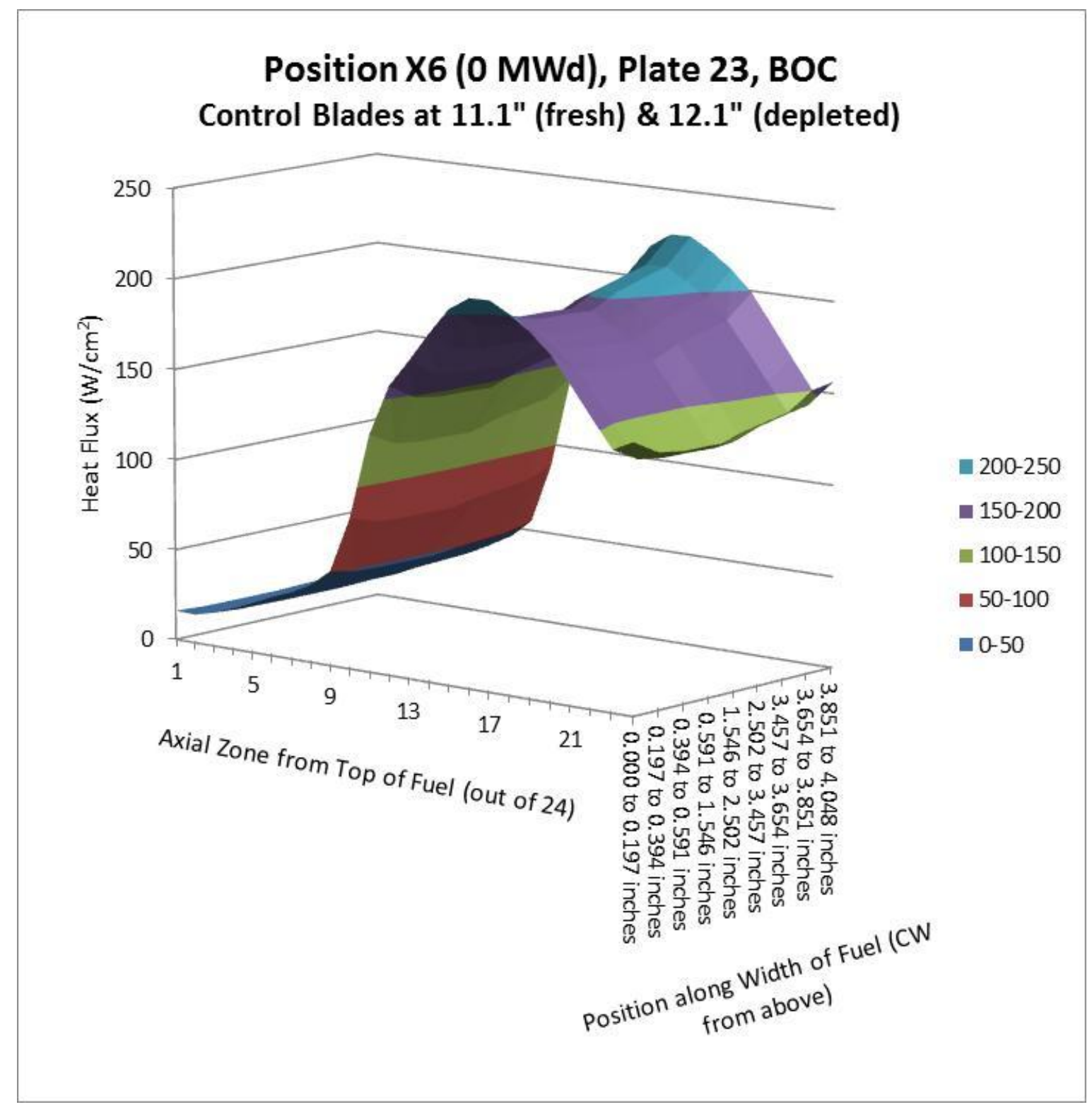

Figure 3.1. Heat Flux $\left(W / \mathrm{cm}^{2}\right)$ for Fresh LEU Fuel Plate in Core 5B1: Position X6, No Xe, Plate 23, Empty FT. 
Table 3.7. Heat Flux $\left(W / \mathrm{cm}^{2}\right)$ for LEU Plate with Maximum Fuel Temperature:

Core 7A1, Position X8 (170 MWd), No Xe, Plate 22, FT loaded with typical samples.

\begin{tabular}{|c|c|c|c|c|c|c|c|c|c|}
\hline \multirow{2}{*}{$\begin{array}{c}\text { Axial } \\
\text { position } \\
\text { from top } \\
\text { of fuel } \\
\text { (inches) }\end{array}$} & \multicolumn{2}{|c|}{ Meat width } & 3.938 & \multicolumn{2}{|l|}{ inches } & \multicolumn{2}{|c|}{ Meat thickness } & 20 & mil \\
\hline & $\begin{array}{c}0.000 \text { to } \\
0.197 \\
\text { inches }\end{array}$ & $\begin{array}{c}0.197 \text { to } \\
0.394 \\
\text { inches }\end{array}$ & $\begin{array}{c}0.394 \text { to } \\
0.591 \\
\text { inches }\end{array}$ & $\begin{array}{c}0.591 \text { to } \\
1.510 \\
\text { inches }\end{array}$ & $\begin{array}{c}1.510 \text { to } \\
2.428 \\
\text { inches }\end{array}$ & $\begin{array}{c}2.428 \text { to } \\
3.347 \\
\text { inches }\end{array}$ & $\begin{array}{c}3.347 \text { to } \\
3.544 \\
\text { inches }\end{array}$ & $\begin{array}{c}3.544 \text { to } \\
3.741 \\
\text { inches }\end{array}$ & $\begin{array}{c}3.741 \text { to } \\
3.938 \\
\text { inches }\end{array}$ \\
\hline 0.5 & 23.21 & 20.97 & 20.09 & 19.63 & 19.21 & 19.53 & 19.71 & 20.57 & 22.81 \\
\hline 1.5 & 22.41 & 20.25 & 19.40 & 18.96 & 18.55 & 18.86 & 19.03 & 19.86 & 22.03 \\
\hline 2.5 & 26.34 & 23.80 & 22.80 & 22.28 & 21.80 & 22.17 & 22.37 & 23.35 & 25.89 \\
\hline 3.5 & 32.96 & 29.78 & 28.53 & 27.87 & 27.28 & 27.73 & 27.99 & 29.21 & 32.39 \\
\hline 4.5 & 41.19 & 37.22 & 35.66 & 34.84 & 34.09 & 34.66 & 34.98 & 36.51 & 40.48 \\
\hline 5.5 & 63.84 & 57.68 & 55.26 & 53.99 & 52.84 & 53.72 & 54.21 & 56.58 & 62.74 \\
\hline 6.5 & 91.13 & 82.34 & 78.88 & 77.08 & 75.43 & 76.69 & 77.39 & 80.77 & 89.56 \\
\hline 7.5 & 110.34 & 99.69 & 95.51 & 93.33 & 91.33 & 92.85 & 93.71 & 97.79 & 108.44 \\
\hline 8.5 & 122.62 & 110.79 & 106.15 & 103.72 & 101.50 & 103.19 & 104.14 & 108.68 & 120.51 \\
\hline 9.5 & 135.68 & 122.59 & 117.45 & 114.76 & 112.31 & 114.18 & 115.23 & 120.25 & 133.34 \\
\hline 10.5 & 146.56 & 132.43 & 126.87 & 123.97 & 121.32 & 123.34 & 124.47 & 129.90 & 144.04 \\
\hline 11.5 & 154.49 & 139.58 & 133.73 & 130.67 & 127.87 & 130.00 & 131.20 & 136.92 & 151.83 \\
\hline 12.5 & 158.77 & 143.45 & 137.43 & 134.29 & 131.42 & 133.60 & 134.83 & 140.71 & 156.03 \\
\hline 13.5 & 161.14 & 145.60 & 139.49 & 136.30 & 133.38 & 135.60 & 136.85 & 142.82 & 158.37 \\
\hline 14.5 & 164.71 & 148.82 & 142.57 & 139.31 & 136.33 & 138.60 & 139.88 & 145.98 & 161.87 \\
\hline 15.5 & 163.02 & 147.29 & 141.11 & 137.88 & 134.94 & 137.18 & 138.45 & 144.48 & 160.21 \\
\hline 16.5 & 163.95 & 148.13 & 141.92 & 138.67 & 135.71 & 137.96 & 139.24 & 145.31 & 161.12 \\
\hline 17.5 & 155.51 & 140.50 & 134.61 & 131.53 & 128.72 & 130.86 & 132.07 & 137.83 & 152.83 \\
\hline 18.5 & 150.66 & 136.12 & 130.41 & 127.43 & 124.70 & 126.78 & 127.95 & 133.53 & 148.06 \\
\hline 19.5 & 142.61 & 128.85 & 123.45 & 120.62 & 118.04 & 120.01 & 121.11 & 126.39 & 140.15 \\
\hline 20.5 & 132.90 & 120.08 & 115.04 & 112.41 & 110.00 & 111.84 & 112.87 & 117.79 & 130.61 \\
\hline 21.5 & 119.64 & 108.09 & 103.56 & 101.19 & 99.03 & 100.67 & 101.60 & 106.03 & 117.57 \\
\hline 22.5 & 108.69 & 98.20 & 94.09 & 91.93 & 89.97 & 91.46 & 92.31 & 96.33 & 106.82 \\
\hline 23.5 & 116.26 & 105.04 & 100.64 & 98.33 & 96.23 & 97.83 & 98.73 & 103.04 & 114.26 \\
\hline Ax. Avg. & 112.86 & 101.97 & 97.69 & 95.46 & 93.42 & 94.97 & 95.85 & 100.03 & 110.91 \\
\hline
\end{tabular}




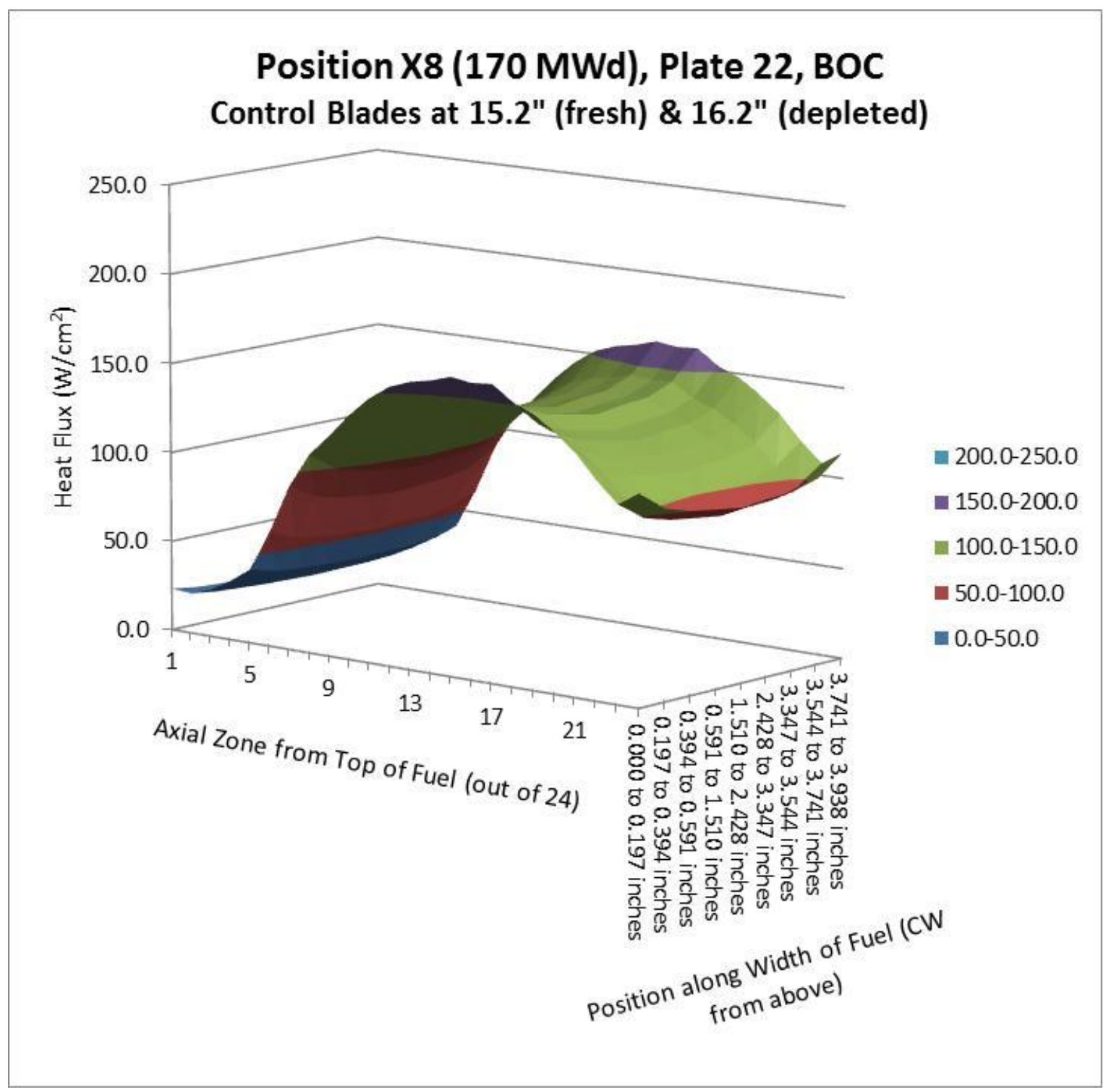

Figure 3.2. Heat Flux $\left(W / \mathrm{cm}^{2}\right)$ for LEU Fuel Plate in Core 7A1: Position X8 (170 MWd), No Xe, Plate 22, FT loaded with typical samples. 


\section{ANL/RERTR/TM-13-1}

Revision 1

Table 3.8. Heat Flux $\left(W / \mathrm{cm}^{2}\right)$ in Reference Mixed Burnup Core: Core 7A, Position X1 (0 MWd), No Xe, Plate 22, FT loaded with typical samples.

\begin{tabular}{|c|c|c|c|c|c|c|c|c|c|}
\hline \multirow{2}{*}{$\begin{array}{c}\text { Axial } \\
\text { position } \\
\text { from top } \\
\text { of fuel } \\
\text { (inches) }\end{array}$} & \multicolumn{2}{|c|}{ Meat width } & 3.938 & \multicolumn{2}{|l|}{ nches } & \multicolumn{2}{|c|}{ Meat thickness } & \multirow{2}{*}{$\begin{array}{c}20 \\
3.544 \text { to } \\
3.741 \\
\text { inches }\end{array}$} & \multirow{2}{*}{$\begin{array}{l}\text { mil } \\
3.741 \text { to } \\
3.938 \\
\text { inches } \\
\end{array}$} \\
\hline & $\begin{array}{c}0.000 \text { to } \\
0.197 \\
\text { inches }\end{array}$ & $\begin{array}{c}0.197 \text { to } \\
0.394 \\
\text { inches }\end{array}$ & $\begin{array}{c}0.394 \text { to } \\
0.591 \\
\text { inches }\end{array}$ & $\begin{array}{c}0.591 \text { to } \\
1.510 \\
\text { inches }\end{array}$ & $\begin{array}{c}1.510 \text { to } \\
2.428 \\
\text { inches }\end{array}$ & $\begin{array}{c}2.428 \text { to } \\
3.347 \\
\text { inches }\end{array}$ & $\begin{array}{c}3.347 \text { to } \\
3.544 \\
\text { inches }\end{array}$ & & \\
\hline 0.5 & 23.21 & 20.96 & 20.26 & 19.44 & 19.02 & 19.36 & 20.00 & 20.70 & 23.75 \\
\hline 1.5 & 23.48 & 20.44 & 19.76 & 18.96 & 18.55 & 18.88 & 19.51 & 20.19 & 23.17 \\
\hline 2.5 & 28.26 & 24.60 & 23.78 & 22.82 & 22.33 & 22.72 & 23.48 & 24.30 & 27.88 \\
\hline 3.5 & 32.96 & 28.69 & 27.73 & 26.61 & 26.04 & 26.50 & 27.38 & 28.33 & 32.52 \\
\hline 4.5 & 38.54 & 33.55 & 32.43 & 31.12 & 30.45 & 30.99 & 32.02 & 33.14 & 38.03 \\
\hline 5.5 & 45.48 & 39.60 & 38.27 & 36.73 & 35.93 & 36.58 & 37.78 & 39.11 & 44.88 \\
\hline 6.5 & 55.23 & 48.08 & 46.48 & 44.60 & 43.64 & 44.42 & 45.88 & 47.49 & 54.50 \\
\hline 7.5 & 70.35 & 61.24 & 59.20 & 56.80 & 55.58 & 56.57 & 58.44 & 60.48 & 69.41 \\
\hline 8.5 & 101.86 & 88.67 & 85.71 & 82.25 & 80.47 & 81.91 & 84.61 & 87.57 & 100.50 \\
\hline 9.5 & 131.30 & 114.30 & 110.49 & 106.02 & 103.73 & 105.58 & 109.07 & 112.88 & 129.55 \\
\hline 10.5 & 149.20 & 129.89 & 125.55 & 120.48 & 117.88 & 119.98 & 123.94 & 128.28 & 147.22 \\
\hline 11.5 & 162.75 & 141.68 & 136.95 & 131.41 & 128.58 & 130.87 & 135.19 & 139.92 & 160.58 \\
\hline 12.5 & 171.09 & 148.94 & 143.97 & 138.15 & 135.17 & 137.58 & 142.13 & 147.10 & 168.82 \\
\hline 13.5 & 178.13 & 155.07 & 149.89 & 143.83 & 140.73 & 143.24 & 147.97 & 153.14 & 175.76 \\
\hline 14.5 & 181.21 & 157.75 & 152.48 & 146.32 & 143.16 & 145.72 & 150.53 & 155.79 & 178.80 \\
\hline 15.5 & 180.14 & 156.82 & 151.58 & 145.45 & 142.31 & 144.86 & 149.64 & 154.87 & 177.74 \\
\hline 16.5 & 177.71 & 154.71 & 149.55 & 143.50 & 140.40 & 142.91 & 147.63 & 152.79 & 175.35 \\
\hline 17.5 & 173.40 & 150.95 & 145.92 & 140.02 & 136.99 & 139.44 & 144.05 & 149.08 & 171.10 \\
\hline 18.5 & 164.57 & 143.26 & 138.48 & 132.88 & 130.02 & 132.34 & 136.71 & 141.49 & 162.38 \\
\hline 19.5 & 156.11 & 135.90 & 131.36 & 126.05 & 123.33 & 125.53 & 129.68 & 134.21 & 154.04 \\
\hline 20.5 & 144.58 & 125.86 & 121.66 & 116.74 & 114.22 & 116.26 & 120.10 & 124.30 & 142.66 \\
\hline 21.5 & 130.37 & 113.50 & 109.71 & 105.27 & 103.00 & 104.84 & 108.30 & 112.09 & 128.64 \\
\hline 22.5 & 116.80 & 101.68 & 98.29 & 94.31 & 92.28 & 93.93 & 97.03 & 100.42 & 115.25 \\
\hline 23.5 & 127.29 & 110.81 & 107.11 & 102.78 & 100.56 & 102.36 & 105.74 & 109.44 & 125.60 \\
\hline Ax. Avg. & 115.20 & 100.29 & 96.94 & 93.02 & 91.02 & 92.64 & 95.70 & 99.05 & 113.67 \\
\hline
\end{tabular}




\section{ANL/RERTR/TM-13-1}

Revision 1

Table 3.9. Heat Flux $\left(\mathrm{W} / \mathrm{cm}^{2}\right)$ in Reference Mixed Burnup Core: Core 7A, Position X7 (77 MWd), No Xe, Plate 22, FT loaded with typical samples.

\begin{tabular}{|c|c|c|c|c|c|c|c|c|c|}
\hline \multirow{2}{*}{$\begin{array}{c}\text { Axial } \\
\text { position } \\
\text { from top } \\
\text { of fuel } \\
\text { (inches) }\end{array}$} & \multicolumn{2}{|c|}{ Meat width } & 3.938 & \multicolumn{2}{|l|}{ inches } & \multicolumn{2}{|c|}{ Meat thickness } & \multirow{2}{*}{$\begin{array}{c}20 \\
3.544 \text { to } \\
3.741 \\
\text { inches } \\
\end{array}$} & \multirow{2}{*}{$\begin{array}{l}\text { mil } \\
3.741 \text { to } \\
3.938 \\
\text { inches } \\
\end{array}$} \\
\hline & $\begin{array}{c}0.000 \text { to } \\
0.197 \\
\text { inches }\end{array}$ & $\begin{array}{c}0.197 \text { to } \\
0.394 \\
\text { inches }\end{array}$ & $\begin{array}{c}0.394 \text { to } \\
0.591 \\
\text { inches }\end{array}$ & $\begin{array}{c}0.591 \text { to } \\
1.510 \\
\text { inches }\end{array}$ & $\begin{array}{c}1.510 \text { to } \\
2.428 \\
\text { inches }\end{array}$ & $\begin{array}{c}2.428 \text { to } \\
3.347 \\
\text { inches }\end{array}$ & $\begin{array}{c}3.347 \text { to } \\
3.544 \\
\text { inches }\end{array}$ & & \\
\hline 0.5 & 24.66 & 21.80 & 20.73 & 20.21 & 19.57 & 20.21 & 20.40 & 21.45 & 24.31 \\
\hline 1.5 & 23.04 & 20.38 & 19.37 & 18.89 & 18.29 & 18.89 & 19.06 & 20.05 & 22.71 \\
\hline 2.5 & 27.89 & 24.67 & 23.45 & 22.87 & 22.14 & 22.87 & 23.08 & 24.27 & 27.50 \\
\hline 3.5 & 32.13 & 28.41 & 27.01 & 26.34 & 25.50 & 26.34 & 26.58 & 27.95 & 31.67 \\
\hline 4.5 & 38.52 & 34.07 & 32.39 & 31.58 & 30.58 & 31.58 & 31.87 & 33.52 & 37.97 \\
\hline 5.5 & 45.16 & 39.94 & 37.97 & 37.02 & 35.85 & 37.02 & 37.36 & 39.29 & 44.52 \\
\hline 6.5 & 53.25 & 47.09 & 44.77 & 43.66 & 42.27 & 43.66 & 44.06 & 46.33 & 52.49 \\
\hline 7.5 & 68.74 & 60.79 & 57.79 & 56.35 & 54.57 & 56.35 & 56.87 & 59.81 & 67.76 \\
\hline 8.5 & 98.03 & 86.69 & 82.42 & 80.36 & 77.81 & 80.36 & 81.10 & 85.29 & 96.63 \\
\hline 9.5 & 127.23 & 112.52 & 106.97 & 104.30 & 101.00 & 104.30 & 105.26 & 110.70 & 125.42 \\
\hline 10.5 & 143.05 & 126.51 & 120.27 & 117.27 & 113.56 & 117.27 & 118.35 & 124.47 & 141.02 \\
\hline 11.5 & 155.96 & 137.92 & 131.12 & 127.85 & 123.80 & 127.85 & 129.03 & 135.69 & 153.73 \\
\hline 12.5 & 162.72 & 143.90 & 136.80 & 133.39 & 129.17 & 133.39 & 134.62 & 141.58 & 160.40 \\
\hline 13.5 & 166.28 & 147.05 & 139.80 & 136.32 & 132.00 & 136.32 & 137.57 & 144.68 & 163.91 \\
\hline 14.5 & 167.43 & 148.06 & 140.76 & 137.26 & 132.90 & 137.26 & 138.52 & 145.68 & 165.04 \\
\hline 15.5 & 166.68 & 147.40 & 140.14 & 136.64 & 132.31 & 136.64 & 137.90 & 145.03 & 164.31 \\
\hline 16.5 & 164.06 & 145.08 & 137.93 & 134.49 & 130.23 & 134.49 & 135.73 & 142.75 & 161.72 \\
\hline 17.5 & 159.19 & 140.77 & 133.83 & 130.50 & 126.36 & 130.50 & 131.70 & 138.50 & 156.92 \\
\hline 18.5 & 152.35 & 134.72 & 128.08 & 124.89 & 120.93 & 124.89 & 126.04 & 132.55 & 150.18 \\
\hline 19.5 & 144.21 & 127.52 & 121.24 & 118.22 & 114.47 & 118.22 & 119.30 & 125.47 & 142.15 \\
\hline 20.5 & 132.78 & 117.42 & 111.64 & 108.85 & 105.40 & 108.85 & 109.86 & 115.53 & 130.89 \\
\hline 21.5 & 121.29 & 107.26 & 101.97 & 99.43 & 96.28 & 99.43 & 100.34 & 105.53 & 119.56 \\
\hline 22.5 & 110.14 & 97.40 & 92.60 & 90.29 & 87.43 & 90.29 & 91.12 & 95.83 & 108.57 \\
\hline 23.5 & 120.88 & 106.89 & 101.62 & 99.09 & 95.95 & 99.09 & 100.00 & 105.17 & 119.15 \\
\hline Ax. Avg. & 108.57 & 96.01 & 91.28 & 89.00 & 86.18 & 89.00 & 89.82 & 94.46 & 107.02 \\
\hline
\end{tabular}




\section{ANL/RERTR/TM-13-1}

Revision 1

Table 3.10. Heat Flux $\left(\mathrm{W} / \mathrm{cm}^{2}\right)$ in Reference Mixed Burnup Core: Core 7A, Position X6 (96 MWd), No Xe, Plate 22, FT loaded with typical samples.

\begin{tabular}{|c|c|c|c|c|c|c|c|c|c|}
\hline \multirow{2}{*}{$\begin{array}{c}\text { Axial } \\
\text { position } \\
\text { from top } \\
\text { of fuel } \\
\text { (inches) }\end{array}$} & \multicolumn{2}{|c|}{ Meat width } & 3.938 & \multicolumn{2}{|l|}{ nches } & \multicolumn{2}{|c|}{ Meat thickness } & \multirow{2}{*}{$\begin{array}{c}20 \\
3.544 \text { to } \\
3.741 \\
\text { inches }\end{array}$} & \multirow{2}{*}{$\begin{array}{l}\text { mil } \\
3.741 \text { to } \\
3.938 \\
\text { inches } \\
\end{array}$} \\
\hline & $\begin{array}{c}0.000 \text { to } \\
0.197 \\
\text { inches }\end{array}$ & $\begin{array}{c}0.197 \text { to } \\
0.394 \\
\text { inches }\end{array}$ & $\begin{array}{c}0.394 \text { to } \\
0.591 \\
\text { inches }\end{array}$ & $\begin{array}{c}0.591 \text { to } \\
1.510 \\
\text { inches }\end{array}$ & $\begin{array}{c}1.510 \text { to } \\
2.428 \\
\text { inches }\end{array}$ & $\begin{array}{c}2.428 \text { to } \\
3.347 \\
\text { inches }\end{array}$ & $\begin{array}{c}3.347 \text { to } \\
3.544 \\
\text { inches }\end{array}$ & & \\
\hline 0.5 & 19.79 & 17.63 & 17.10 & 16.68 & 16.27 & 16.80 & 17.14 & 17.82 & 20.08 \\
\hline 1.5 & 19.66 & 17.53 & 17.00 & 16.57 & 16.17 & 16.69 & 17.03 & 17.71 & 19.95 \\
\hline 2.5 & 22.56 & 20.11 & 19.50 & 19.01 & 18.55 & 19.15 & 19.54 & 20.32 & 22.89 \\
\hline 3.5 & 26.52 & 23.64 & 22.93 & 22.35 & 21.80 & 22.51 & 22.97 & 23.89 & 26.91 \\
\hline 4.5 & 30.66 & 27.32 & 26.50 & 25.84 & 25.21 & 26.03 & 26.56 & 27.62 & 31.11 \\
\hline 5.5 & 36.29 & 32.34 & 31.37 & 30.58 & 29.83 & 30.80 & 31.43 & 32.68 & 36.82 \\
\hline 6.5 & 43.23 & 38.53 & 37.37 & 36.44 & 35.54 & 36.70 & 37.45 & 38.94 & 43.87 \\
\hline 7.5 & 56.66 & 50.50 & 48.98 & 47.76 & 46.58 & 48.10 & 49.08 & 51.04 & 57.49 \\
\hline 8.5 & 91.10 & 81.19 & 78.75 & 76.78 & 74.89 & 77.33 & 78.90 & 82.05 & 92.44 \\
\hline 9.5 & 123.58 & 110.13 & 106.83 & 104.16 & 101.60 & 104.91 & 107.04 & 111.31 & 125.40 \\
\hline 10.5 & 141.75 & 126.33 & 122.53 & 119.47 & 116.53 & 120.33 & 122.78 & 127.67 & 143.83 \\
\hline 11.5 & 153.05 & 136.40 & 132.30 & 129.00 & 125.83 & 129.92 & 132.57 & 137.85 & 155.30 \\
\hline 12.5 & 160.79 & 143.29 & 138.99 & 135.52 & 132.19 & 136.49 & 139.27 & 144.82 & 163.15 \\
\hline 13.5 & 166.56 & 148.43 & 143.98 & 140.38 & 136.93 & 141.39 & 144.26 & 150.02 & 169.00 \\
\hline 14.5 & 170.02 & 151.52 & 146.97 & 143.30 & 139.78 & 144.33 & 147.27 & 153.14 & 172.52 \\
\hline 15.5 & 169.30 & 150.88 & 146.34 & 142.69 & 139.18 & 143.71 & 146.64 & 152.48 & 171.78 \\
\hline 16.5 & 166.72 & 148.58 & 144.12 & 140.52 & 137.07 & 141.53 & 144.41 & 150.17 & 169.17 \\
\hline 17.5 & 161.73 & 144.13 & 139.80 & 136.31 & 132.96 & 137.29 & 140.08 & 145.66 & 164.10 \\
\hline 18.5 & 154.99 & 138.12 & 133.98 & 130.63 & 127.42 & 131.57 & 134.24 & 139.60 & 157.26 \\
\hline 19.5 & 144.11 & 128.43 & 124.57 & 121.46 & 118.47 & 122.33 & 124.82 & 129.79 & 146.22 \\
\hline 20.5 & 133.01 & 118.54 & 114.98 & 112.10 & 109.35 & 112.91 & 115.21 & 119.80 & 134.96 \\
\hline 21.5 & 120.74 & 107.60 & 104.37 & 101.76 & 99.26 & 102.49 & 104.58 & 108.75 & 122.51 \\
\hline 22.5 & 109.26 & 97.37 & 94.45 & 92.09 & 89.83 & 92.75 & 94.64 & 98.41 & 110.87 \\
\hline 23.5 & 116.34 & 103.68 & 100.57 & 98.06 & 95.65 & 98.76 & 100.77 & 104.79 & 118.05 \\
\hline Ax. Avg. & 105.77 & 94.26 & 91.43 & 89.14 & 86.95 & 89.78 & 91.61 & 95.26 & 107.32 \\
\hline
\end{tabular}




\section{ANL/RERTR/TM-13-1}

Revision 1

Table 3.11. Heat Flux $\left(\mathrm{W} / \mathrm{cm}^{2}\right)$ in Reference Mixed Burnup Core: Core 7A, Position X8 (170 MWd), No Xe, Plate 22, FT loaded with typical samples.

\begin{tabular}{|c|c|c|c|c|c|c|c|c|c|}
\hline \multirow{2}{*}{$\begin{array}{c}\text { Axial } \\
\text { position } \\
\text { from top } \\
\text { of fuel } \\
\text { (inches) }\end{array}$} & \multicolumn{2}{|c|}{ Meat width } & 3.938 & \multicolumn{2}{|l|}{ inches } & \multicolumn{2}{|c|}{ Meat thickness } & \multirow{2}{*}{$\begin{array}{c}20 \\
3.544 \text { to } \\
3.741 \\
\text { inches } \\
\end{array}$} & \multirow{2}{*}{$\begin{array}{l}\text { mil } \\
3.741 \text { to } \\
3.938 \\
\text { inches } \\
\end{array}$} \\
\hline & $\begin{array}{c}0.000 \text { to } \\
0.197 \\
\text { inches }\end{array}$ & $\begin{array}{c}0.197 \text { to } \\
0.394 \\
\text { inches }\end{array}$ & $\begin{array}{c}0.394 \text { to } \\
0.591 \\
\text { inches }\end{array}$ & $\begin{array}{c}0.591 \text { to } \\
1.510 \\
\text { inches }\end{array}$ & $\begin{array}{c}1.510 \text { to } \\
2.428 \\
\text { inches }\end{array}$ & $\begin{array}{c}2.428 \text { to } \\
3.347 \\
\text { inches }\end{array}$ & $\begin{array}{c}3.347 \text { to } \\
3.544 \\
\text { inches }\end{array}$ & & \\
\hline 0.5 & 18.19 & 16.15 & 15.58 & 15.36 & 15.04 & 15.48 & 15.93 & 16.54 & 18.48 \\
\hline 1.5 & 17.93 & 15.92 & 15.36 & 15.14 & 14.83 & 15.26 & 15.70 & 16.30 & 18.21 \\
\hline 2.5 & 20.68 & 18.35 & 17.71 & 17.46 & 17.10 & 17.60 & 18.10 & 18.80 & 21.00 \\
\hline 3.5 & 24.92 & 22.12 & 21.34 & 21.04 & 20.60 & 21.21 & 21.81 & 22.65 & 25.31 \\
\hline 4.5 & 27.99 & 24.84 & 23.97 & 23.63 & 23.14 & 23.82 & 24.50 & 25.45 & 28.43 \\
\hline 5.5 & 33.63 & 29.85 & 28.80 & 28.39 & 27.81 & 28.62 & 29.44 & 30.57 & 34.15 \\
\hline 6.5 & 38.22 & 33.92 & 32.73 & 32.26 & 31.60 & 32.53 & 33.46 & 34.75 & 38.82 \\
\hline 7.5 & 53.14 & 47.15 & 45.50 & 44.85 & 43.93 & 45.22 & 46.51 & 48.30 & 53.96 \\
\hline 8.5 & 87.04 & 77.25 & 74.53 & 73.48 & 71.97 & 74.08 & 76.19 & 79.13 & 88.40 \\
\hline 9.5 & 117.38 & 104.17 & 100.51 & 99.09 & 97.06 & 99.90 & 102.75 & 106.71 & 119.21 \\
\hline 10.5 & 134.74 & 119.58 & 115.38 & 113.74 & 111.41 & 114.68 & 117.94 & 122.49 & 136.84 \\
\hline 11.5 & 145.65 & 129.26 & 124.72 & 122.95 & 120.43 & 123.96 & 127.49 & 132.41 & 147.92 \\
\hline 12.5 & 151.67 & 134.60 & 129.87 & 128.03 & 125.41 & 129.08 & 132.76 & 137.88 & 154.03 \\
\hline 13.5 & 158.30 & 140.48 & 135.55 & 133.63 & 130.89 & 134.72 & 138.56 & 143.91 & 160.76 \\
\hline 14.5 & 160.53 & 142.46 & 137.45 & 135.51 & 132.73 & 136.62 & 140.51 & 145.93 & 163.03 \\
\hline 15.5 & 161.10 & 142.97 & 137.95 & 136.00 & 133.21 & 137.11 & 141.02 & 146.46 & 163.61 \\
\hline 16.5 & 160.18 & 142.15 & 137.16 & 135.22 & 132.44 & 136.33 & 140.21 & 145.62 & 162.68 \\
\hline 17.5 & 154.59 & 137.19 & 132.37 & 130.50 & 127.82 & 131.57 & 135.31 & 140.53 & 157.00 \\
\hline 18.5 & 150.70 & 133.74 & 129.04 & 127.22 & 124.61 & 128.26 & 131.91 & 137.00 & 153.05 \\
\hline 19.5 & 141.60 & 125.66 & 121.25 & 119.53 & 117.08 & 120.51 & 123.94 & 128.73 & 143.80 \\
\hline 20.5 & 131.82 & 116.98 & 112.87 & 111.27 & 108.99 & 112.19 & 115.38 & 119.83 & 133.87 \\
\hline 21.5 & 119.45 & 106.00 & 102.28 & 100.83 & 98.76 & 101.66 & 104.56 & 108.59 & 121.31 \\
\hline 22.5 & 107.76 & 95.63 & 92.27 & 90.97 & 89.10 & 91.71 & 94.33 & 97.96 & 109.44 \\
\hline 23.5 & 117.50 & 104.27 & 100.61 & 99.19 & 97.15 & 100.00 & 102.85 & 106.82 & 119.33 \\
\hline Ax. Avg. & 101.45 & 90.03 & 86.87 & 85.64 & 83.88 & 86.34 & 88.80 & 92.22 & 103.03 \\
\hline
\end{tabular}




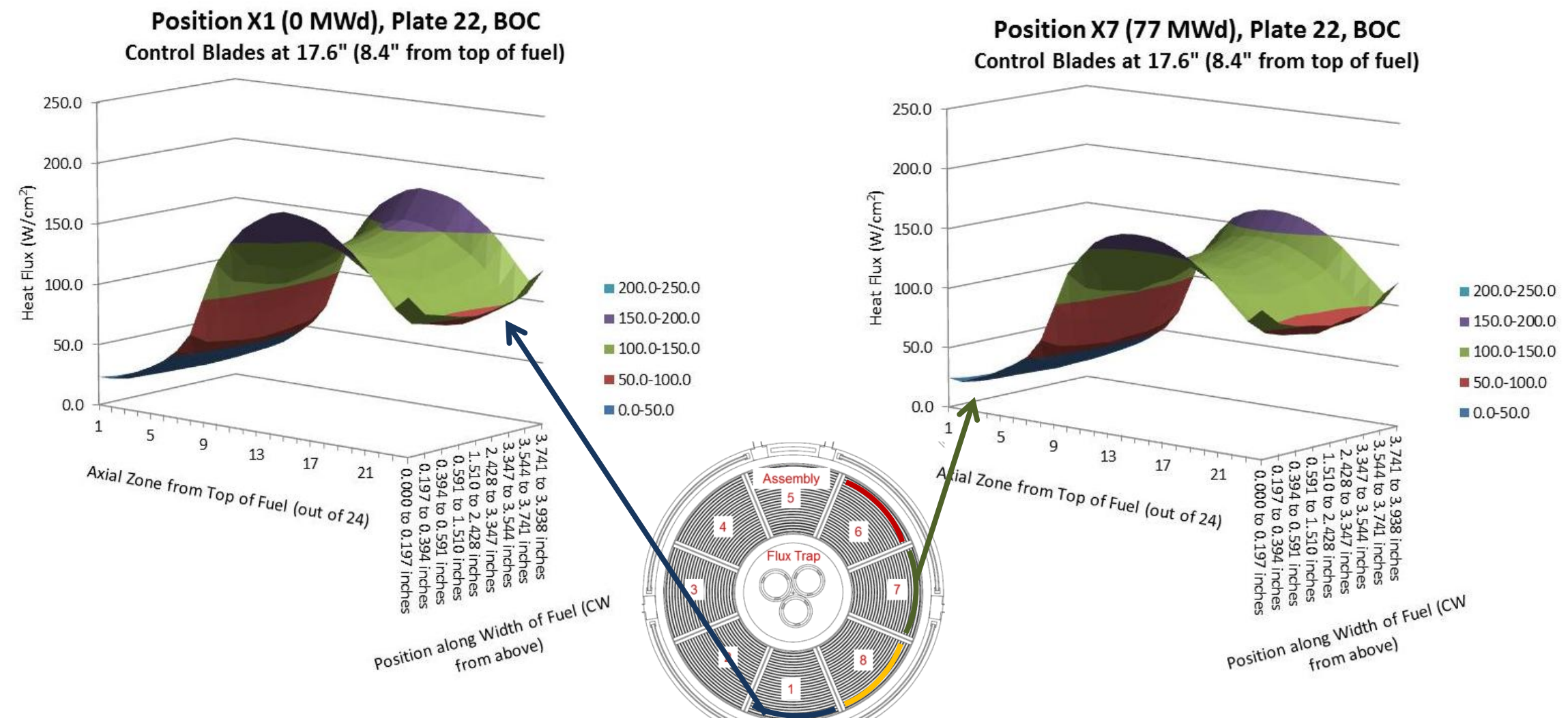

Position X1, 0 MWd, No Xe, Plate 22, FT loaded with typical samples

Position X7, 77 MWd, No Xe, Plate 22, FT loaded with typical samples

Figure 3.3. Evolution of Heat Flux $\left(\mathrm{W} / \mathrm{cm}^{2}\right)$ for LEU Fuel Plate in Core 7A: Element burnups at 0 and $77 \mathrm{MWd}$. 


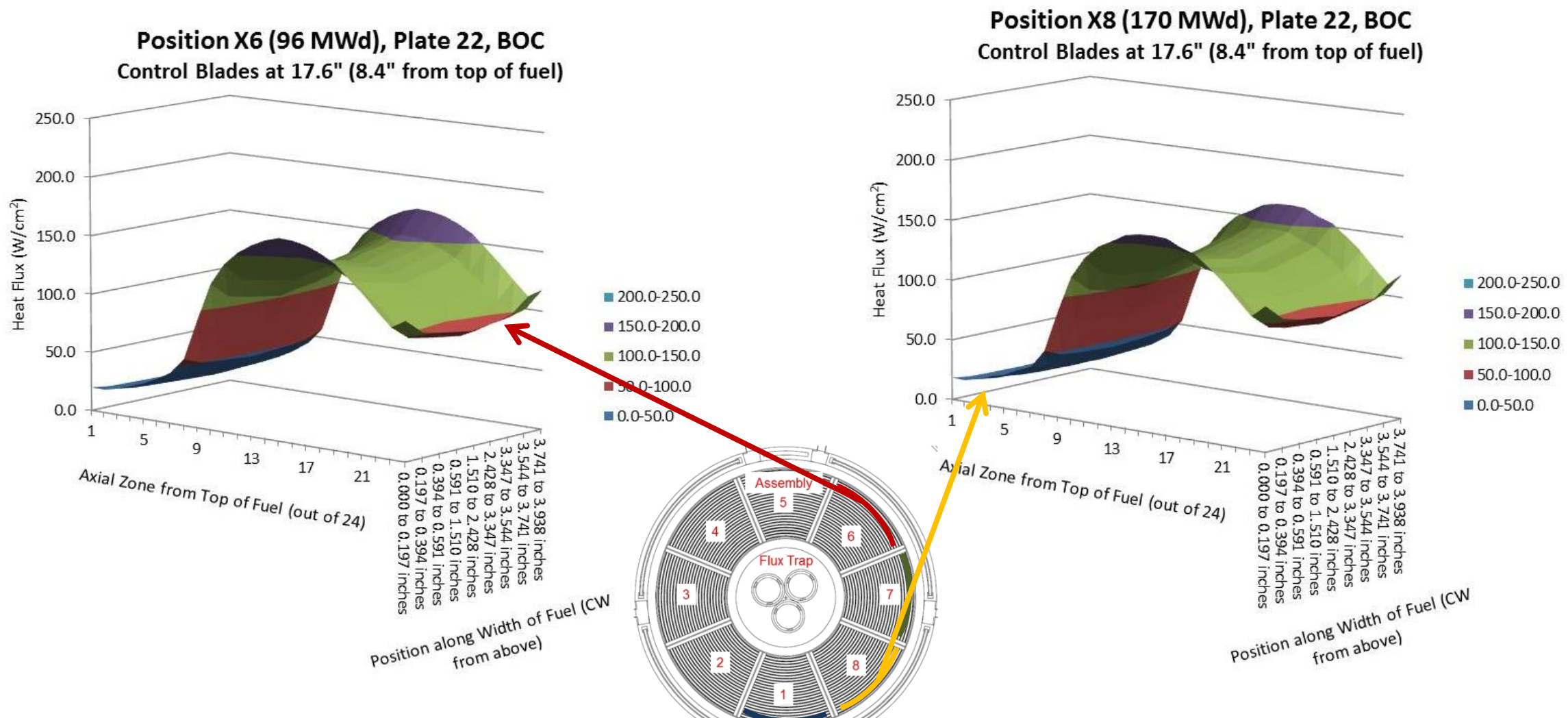

Position X6, 96 MWd, No Xe, Plate 22, FT loaded with typical samples

Figure 3.4. Evolution of Heat Flux $\left(\mathrm{W} / \mathrm{cm}^{2}\right)$ for LEU Fuel Plate in Core 7A: Element burnups at 96 and 170 MWd. 


\subsubsection{Fission Rate Density}

Table 3.12 provides the 2-D fission rate density profile for the plate that has the greatest fission rate density of all the steady-state cores examined. This occurs in plate 1 of core 5B1 (near the center flux trap) in element position 7. Note that this is a different plate in the core than the location of the peak local heat flux (Section 3.3.1). Even though plate 1 has the highest fission rate density, it also has the thinnest foil thickness, producing an acceptable heat flux. A contour plot of the fission rate density for this plate is shown in Figure 3.5.

It is of interest to observe how the fission rate density evolves in a fuel plate loaded in the MURR during its lifetime. Tables 3.13 to 3.16 provide the fission rate density profiles for plate 1 in elements at four different core positions at BOC in core 7A. This core was modeled with experimental samples in the flux trap and irradiation materials in the graphite reflector that are typical for weekly MURR operations. Furthermore, this core has a mix of fuel elements at burnups that are expected to be typical for the MURR at "pseudo-equilibrium." The fuel burnup conditions were derived from the extensive fuel cycle simulation study reported in Reference 1 that was performed with REBUS-DIF3D.

Each profile in Tables 3.13 to 3.16 is for a plate next to the center flux trap that has reached a different burnup in its expected lifetime under steady-state conditions. Figures 3.6 and 3.7 show the fission rate density profile contours for the plates at each point in the burnup history, and illustrate the significant reduction and flattening of the fission rate density that occurs with depletion. The burnup indicated in these tables and figures is the average burnup for the entire element. It should be noted that the data presented in these tables and figures are under xenon-free conditions, even for those plates which have experienced prior burnup. The xenon-free conditions were chosen for display because the peak fission rate density for a given element will be greater than under equilibrium-xenon conditions (see comparison of cores 7A and 8A in Table 3.5).

\subsubsection{Fission Density}

Table 3.17 provides the fission density (fissions $/ \mathrm{cm}^{3}$ ) averaged for each plate, and the peak local burnup for each plate with axial and azimuthal factors applied, for an element discharged from a reference "pseudo-equilibrium" cycle in MURR. The total burnup for this element calculated in the fuel cycle simulation was $180.1 \mathrm{MWd}$. The fuel cycle simulation performed with REBUS-DIF3D provided an axial burnup peaking factor for each plate based on 12 axial depletion zones in each plate (2 inch segments). The fuel was not subdivided azimuthally in the REBUS-DIF3D model due to the large number of depletion zones that would have created, so an azimuthal peaking factor from the MCNP power distribution analysis was applied to obtain the peak local burnup values. The calculated peak local burnup for the LEU fuel in MURR is $3.372 \times 10^{21}$ fissions $/ \mathrm{cm}^{3}$. This includes fission in all fissionable isotopes, not solely ${ }^{235} \mathrm{U}$. Figure 3.8 provides a plot of the radial profile (plate-by-plate) of the fission density; both plate average and local burnup values with all peaking factors applied are presented. Table 3.18 compares the average and peak burnup values by axial segment for the 3 most highly burned plates in the discharged element. The axial burnup profiles for these plates are plotted in Figure 3.9. 


\section{ANL/RERTR/TM-13-1 \\ Revision 1}

Table 3.12. Maximum Fission Rate Density (fissions $/ \mathrm{cm}^{3}$-s) of All Steady-State Cores:

Fresh LEU Element in Core 5B1, Position X7, No Xe, Plate 1, Empty FT.

\begin{tabular}{|c|c|c|c|c|c|c|c|c|c|}
\hline \multirow{2}{*}{$\begin{array}{c}\text { Axial } \\
\text { position } \\
\text { from top } \\
\text { of fuel } \\
\text { (inches) }\end{array}$} & \multicolumn{2}{|r|}{ Meat width } & 1.690 & \multicolumn{2}{|l|}{ inches } & \multicolumn{2}{|c|}{ Meat thickness } & 9 & mil \\
\hline & $\begin{array}{c}0.000 \text { to } \\
0.197 \\
\text { inches }\end{array}$ & $\begin{array}{c}0.197 \text { to } \\
0.394 \\
\text { inches }\end{array}$ & $\begin{array}{c}0.394 \text { to } \\
0.591 \\
\text { inches }\end{array}$ & $\begin{array}{c}0.591 \text { to } \\
0.760 \\
\text { inches }\end{array}$ & $\begin{array}{c}0.760 \text { to } \\
0.930 \\
\text { inches }\end{array}$ & $\begin{array}{c}0.930 \text { to } \\
1.099 \\
\text { inches }\end{array}$ & $\begin{array}{c}1.099 \text { to } \\
1.296 \\
\text { inches }\end{array}$ & $\begin{array}{c}1.296 \text { to } \\
1.493 \\
\text { inches }\end{array}$ & $\begin{array}{c}1.493 \text { to } \\
1.690 \\
\text { inches }\end{array}$ \\
\hline 0.5 & $1.21 \mathrm{E}+14$ & $1.22 \mathrm{E}+14$ & $1.18 E+14$ & $1.18 E+14$ & $1.15 E+14$ & $1.22 \mathrm{E}+14$ & $1.20 \mathrm{E}+14$ & $1.26 \mathrm{E}+14$ & $1.21 \mathrm{E}+14$ \\
\hline 1.5 & $1.32 \mathrm{E}+14$ & $1.29 \mathrm{E}+14$ & $1.19 \mathrm{E}+14$ & $1.16 \mathrm{E}+14$ & $1.23 E+14$ & $1.28 \mathrm{E}+14$ & $1.23 E+14$ & $1.22 \mathrm{E}+14$ & $1.26 \mathrm{E}+14$ \\
\hline 2.5 & $1.47 \mathrm{E}+14$ & $1.51 \mathrm{E}+14$ & $1.45 \mathrm{E}+14$ & $1.47 E+14$ & $1.36 \mathrm{E}+14$ & $1.47 \mathrm{E}+14$ & $1.46 \mathrm{E}+14$ & $1.45 \mathrm{E}+14$ & $1.42 \mathrm{E}+14$ \\
\hline 3.5 & $1.84 \mathrm{E}+14$ & $1.72 \mathrm{E}+14$ & $1.71 \mathrm{E}+14$ & $1.67 E+14$ & $1.70 \mathrm{E}+14$ & $1.76 \mathrm{E}+14$ & $1.76 \mathrm{E}+14$ & $1.69 \mathrm{E}+14$ & $1.78 \mathrm{E}+14$ \\
\hline 4.5 & $2.07 E+14$ & $2.02 E+14$ & $2.05 E+14$ & $1.94 E+14$ & $1.88 \mathrm{E}+14$ & $2.01 \mathrm{E}+14$ & $2.00 E+14$ & $2.07 \mathrm{E}+14$ & $2.12 \mathrm{E}+14$ \\
\hline 5.5 & $2.39 \mathrm{E}+14$ & $2.32 \mathrm{E}+14$ & $2.22 \mathrm{E}+14$ & $2.35 E+14$ & $2.14 \mathrm{E}+14$ & $2.31 \mathrm{E}+14$ & $2.31 \mathrm{E}+14$ & $2.31 \mathrm{E}+14$ & $2.41 \mathrm{E}+14$ \\
\hline 6.5 & $2.68 \mathrm{E}+14$ & $2.65 \mathrm{E}+14$ & $2.71 E+14$ & $2.68 \mathrm{E}+14$ & $2.64 \mathrm{E}+14$ & $2.63 E+14$ & $2.65 \mathrm{E}+14$ & $2.59 \mathrm{E}+14$ & $2.63 \mathrm{E}+14$ \\
\hline 7.5 & $2.96 \mathrm{E}+14$ & $2.99 \mathrm{E}+14$ & $2.94 \mathrm{E}+14$ & $2.94 \mathrm{E}+14$ & $2.76 \mathrm{E}+14$ & $2.88 \mathrm{E}+14$ & $2.91 E+14$ & $3.00 \mathrm{E}+14$ & $3.17 \mathrm{E}+14$ \\
\hline 8.5 & $3.38 \mathrm{E}+14$ & $3.27 \mathrm{E}+14$ & $3.19 E+14$ & $3.23 E+14$ & $3.06 E+14$ & $3.22 E+14$ & $3.23 E+14$ & $3.18 \mathrm{E}+14$ & $3.37 \mathrm{E}+14$ \\
\hline 9.5 & $3.73 E+14$ & $3.62 \mathrm{E}+14$ & $3.50 \mathrm{E}+14$ & $3.64 E+14$ & $3.46 \mathrm{E}+14$ & $3.57 E+14$ & $3.56 \mathrm{E}+14$ & $3.63 E+14$ & $3.69 E+14$ \\
\hline 10.5 & $4.08 \mathrm{E}+14$ & $3.88 \mathrm{E}+14$ & $3.86 \mathrm{E}+14$ & $3.89 E+14$ & $3.67 E+14$ & $3.98 \mathrm{E}+14$ & $3.94 \mathrm{E}+14$ & $3.87 \mathrm{E}+14$ & $4.01 \mathrm{E}+14$ \\
\hline 11.5 & $4.21 E+14$ & $4.20 \mathrm{E}+14$ & $4.14 \mathrm{E}+14$ & $4.14 E+14$ & $4.08 E+14$ & $4.28 \mathrm{E}+14$ & $4.14 \mathrm{E}+14$ & $4.17 \mathrm{E}+14$ & $4.28 \mathrm{E}+14$ \\
\hline 12.5 & $4.65 \mathrm{E}+14$ & $4.46 \mathrm{E}+14$ & $4.37 E+14$ & $4.38 \mathrm{E}+14$ & $4.17 E+14$ & $4.46 \mathrm{E}+14$ & $4.48 \mathrm{E}+14$ & $4.48 \mathrm{E}+14$ & $4.50 \mathrm{E}+14$ \\
\hline 13.5 & $4.75 \mathrm{E}+14$ & $4.72 \mathrm{E}+14$ & $4.62 \mathrm{E}+14$ & $4.60 \mathrm{E}+14$ & $4.37 E+14$ & $4.61 \mathrm{E}+14$ & $4.59 \mathrm{E}+14$ & $4.56 \mathrm{E}+14$ & $4.78 \mathrm{E}+14$ \\
\hline 14.5 & $4.89 \mathrm{E}+14$ & $4.84 \mathrm{E}+14$ & $4.75 \mathrm{E}+14$ & $4.70 \mathrm{E}+14$ & $4.53 \mathrm{E}+14$ & $4.74 \mathrm{E}+14$ & $4.63 \mathrm{E}+14$ & $4.67 \mathrm{E}+14$ & $4.80 \mathrm{E}+14$ \\
\hline 15.5 & $5.09 E+14$ & $4.80 \mathrm{E}+14$ & $4.70 \mathrm{E}+14$ & $4.75 E+14$ & $4.50 E+14$ & $4.71 E+14$ & $4.72 \mathrm{E}+14$ & $4.72 \mathrm{E}+14$ & $4.99 \mathrm{E}+14$ \\
\hline 16.5 & $4.98 \mathrm{E}+14$ & $4.90 \mathrm{E}+14$ & $4.82 \mathrm{E}+14$ & $4.69 E+14$ & $4.35 E+14$ & $4.74 \mathrm{E}+14$ & $4.75 \mathrm{E}+14$ & $4.88 \mathrm{E}+14$ & $4.91 E+14$ \\
\hline 17.5 & $5.03 E+14$ & $4.75 \mathrm{E}+14$ & $4.62 \mathrm{E}+14$ & $4.59 \mathrm{E}+14$ & $4.39 E+14$ & $4.55 E+14$ & $4.64 \mathrm{E}+14$ & $4.58 \mathrm{E}+14$ & $4.88 \mathrm{E}+14$ \\
\hline 18.5 & $4.81 E+14$ & $4.51 \mathrm{E}+14$ & $4.48 E+14$ & $4.52 E+14$ & $4.18 E+14$ & $4.56 \mathrm{E}+14$ & $4.39 \mathrm{E}+14$ & $4.50 \mathrm{E}+14$ & $4.74 \mathrm{E}+14$ \\
\hline 19.5 & $4.44 \mathrm{E}+14$ & $4.21 E+14$ & $4.20 \mathrm{E}+14$ & $4.17 E+14$ & $3.96 \mathrm{E}+14$ & $4.32 \mathrm{E}+14$ & $4.27 \mathrm{E}+14$ & $4.37 \mathrm{E}+14$ & $4.49 \mathrm{E}+14$ \\
\hline 20.5 & $3.91 \mathrm{E}+14$ & $3.89 E+14$ & $3.82 \mathrm{E}+14$ & $3.86 \mathrm{E}+14$ & $3.65 E+14$ & $3.89 \mathrm{E}+14$ & $3.83 \mathrm{E}+14$ & $3.91 \mathrm{E}+14$ & $4.02 \mathrm{E}+14$ \\
\hline 21.5 & $3.64 \mathrm{E}+14$ & $3.47 \mathrm{E}+14$ & $3.47 E+14$ & $3.43 E+14$ & $3.22 \mathrm{E}+14$ & $3.42 \mathrm{E}+14$ & $3.52 \mathrm{E}+14$ & $3.56 \mathrm{E}+14$ & $3.72 \mathrm{E}+14$ \\
\hline 22.5 & $3.28 \mathrm{E}+14$ & $3.07 \mathrm{E}+14$ & $3.11 \mathrm{E}+14$ & $3.18 E+14$ & $2.99 E+14$ & $3.15 E+14$ & $3.05 E+14$ & $3.18 \mathrm{E}+14$ & $3.30 \mathrm{E}+14$ \\
\hline 23.5 & $3.30 \mathrm{E}+14$ & $3.21 \mathrm{E}+14$ & $3.17 \mathrm{E}+14$ & $3.05 E+14$ & $2.97 E+14$ & $3.10 \mathrm{E}+14$ & $3.15 \mathrm{E}+14$ & $3.25 \mathrm{E}+14$ & $3.35 \mathrm{E}+14$ \\
\hline Ax. Avg. & $3.50 \mathrm{E}+14$ & $3.40 \mathrm{E}+14$ & $3.35 E+14$ & $3.34 \mathrm{E}+14$ & $3.18 \mathrm{E}+14$ & $3.37 E+14$ & $3.35 E+14$ & $3.38 \mathrm{E}+14$ & $3.49 E+14$ \\
\hline
\end{tabular}




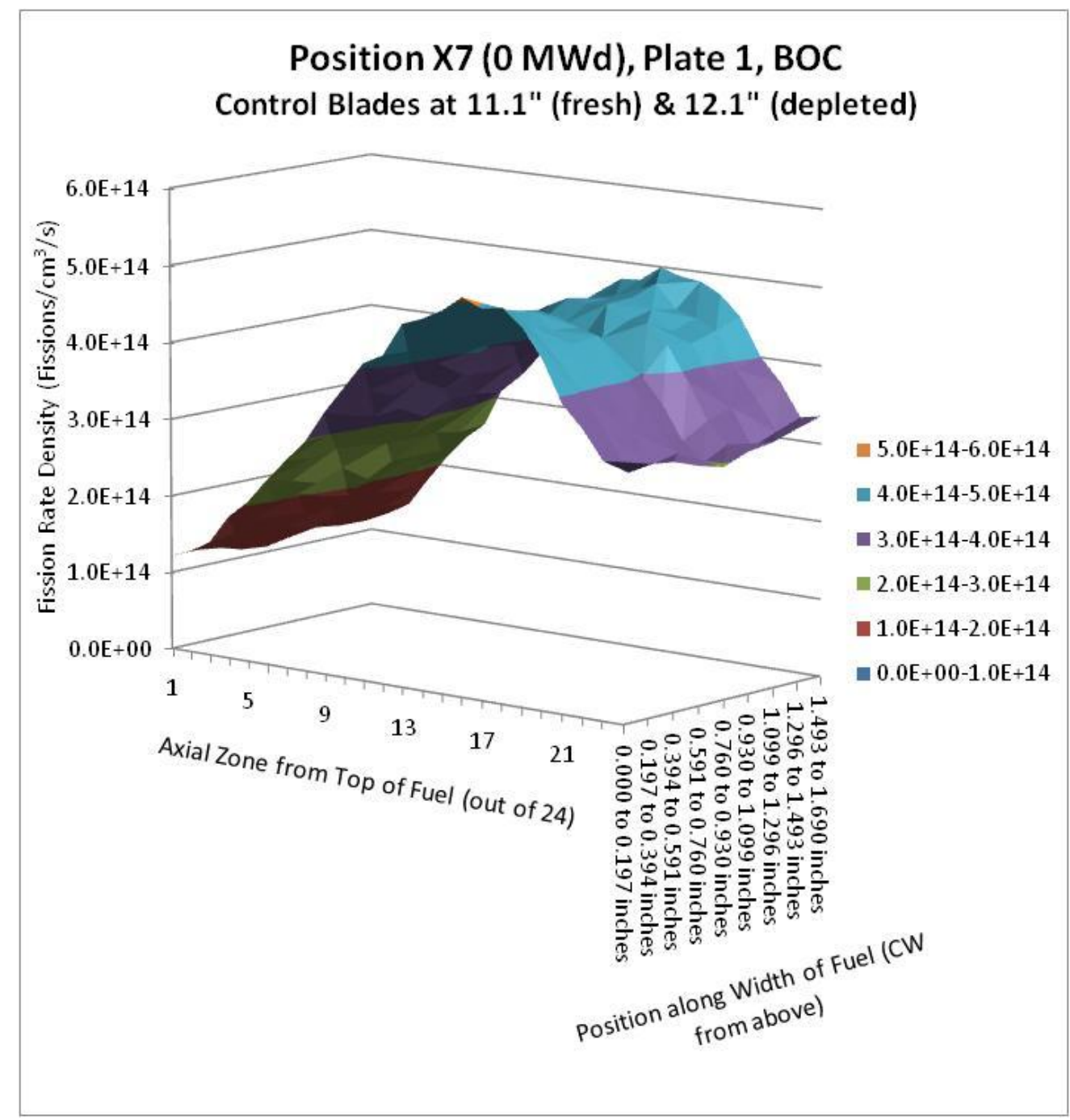

Figure 3.5. Fission Rate Density (fissions $/ \mathrm{cm}^{3}$-s) for Fresh LEU Fuel Plate in Core 5B1: Position X7, No Xe, Plate 1, Empty FT. 


\section{ANL/RERTR/TM-13-1 \\ Revision 1}

Table 3.13. Fission Rate Density (fissions $/ \mathrm{cm}^{3}$-s) in Reference Mixed Burnup Core:

Core 7A, Position X5 (0 MWd), No Xe, Plate 1, FT loaded with typical samples.

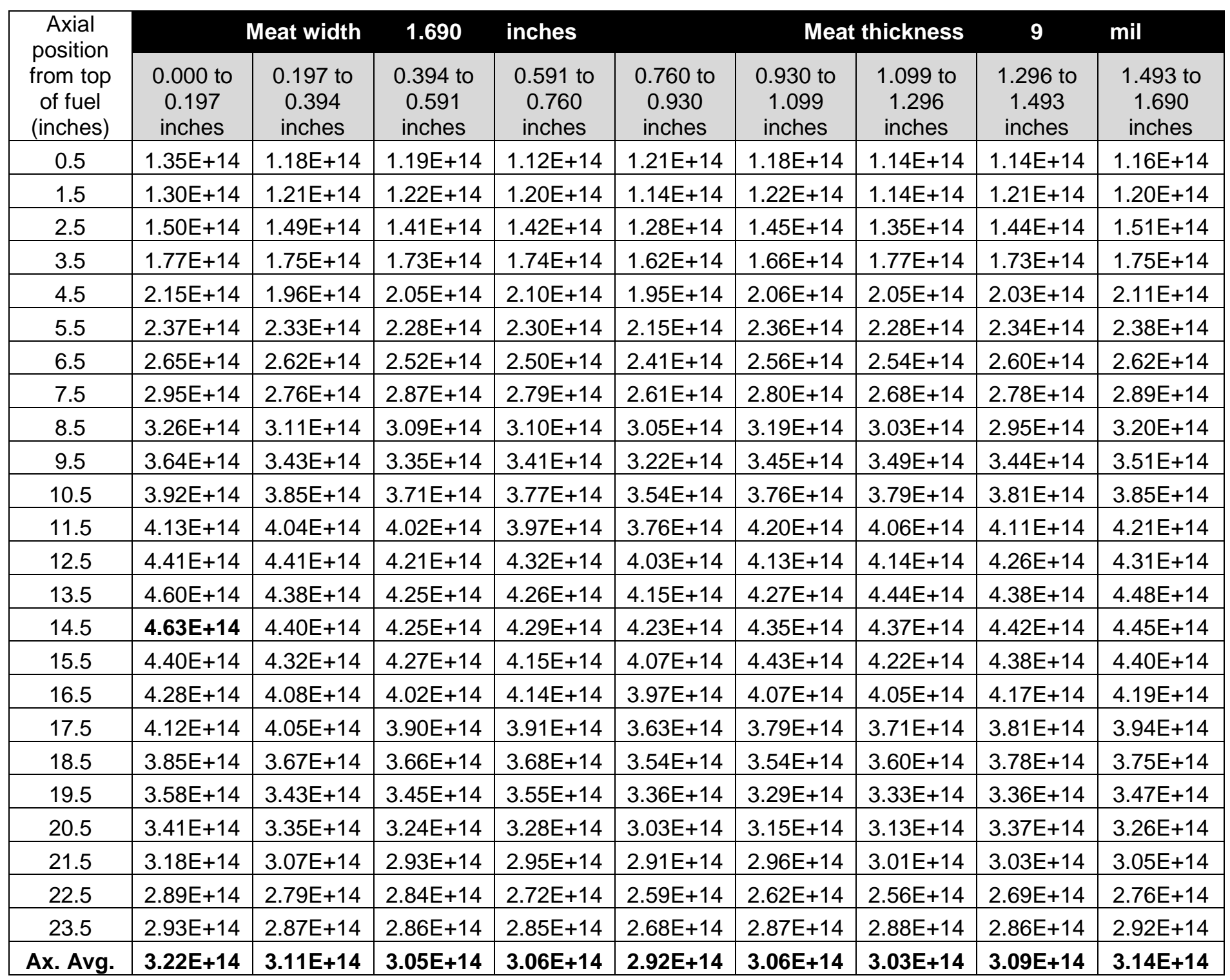




\section{ANL/RERTR/TM-13-1 \\ Revision 1}

Table 3.14. Fission Rate Density (fissions $/ \mathrm{cm}^{3}$-s) in Reference Mixed Burnup Core:

Core 7A, Position X3 (77 MWd), No Xe, Plate 1, FT loaded with typical samples.

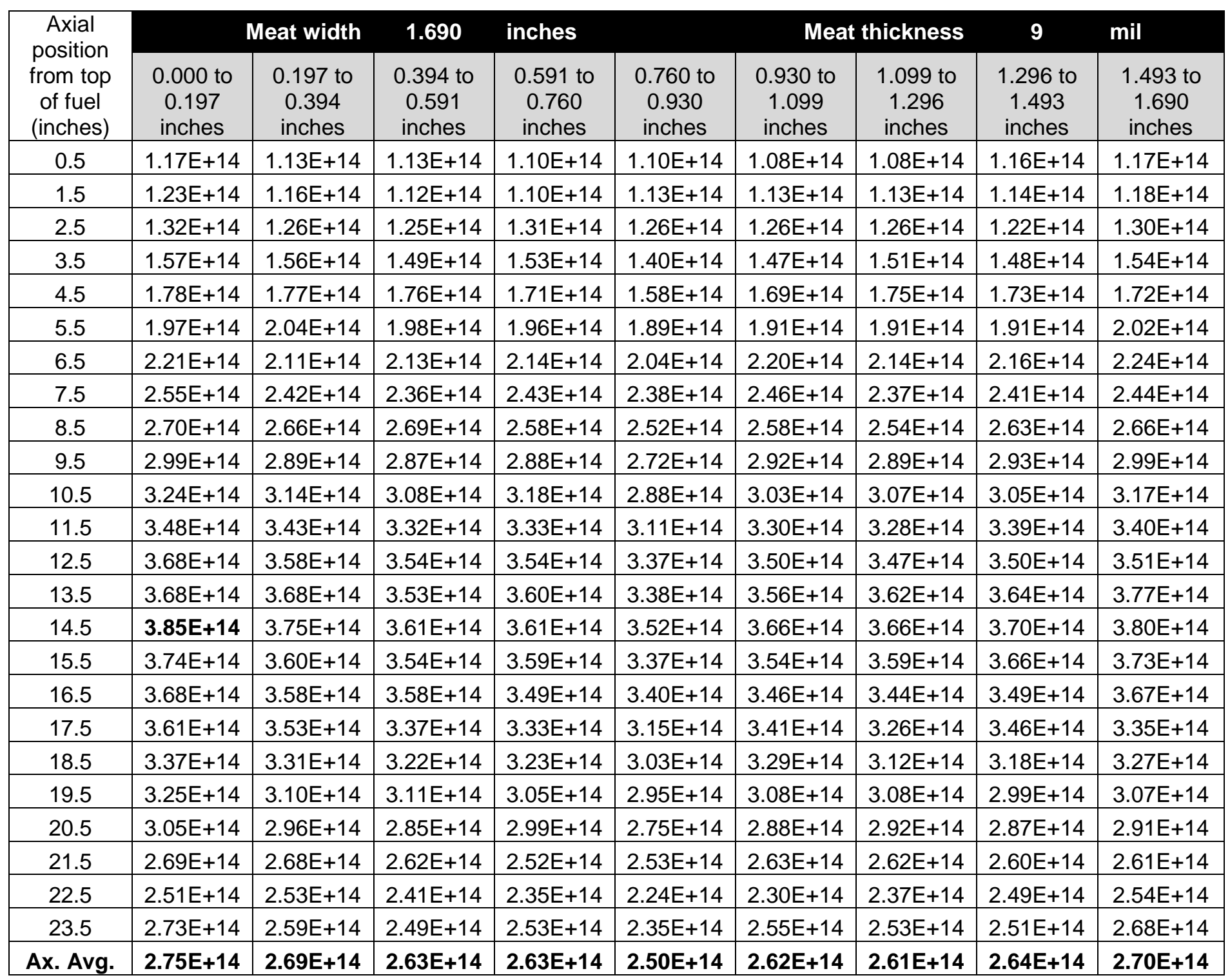




\section{ANL/RERTR/TM-13-1 \\ Revision 1}

Table 3.15. Fission Rate Density (fissions $/ \mathrm{cm}^{3}$-s) in Reference Mixed Burnup Core:

Core 7A, Position X2 (96 MWd), No Xe, Plate 1, FT loaded with typical samples.

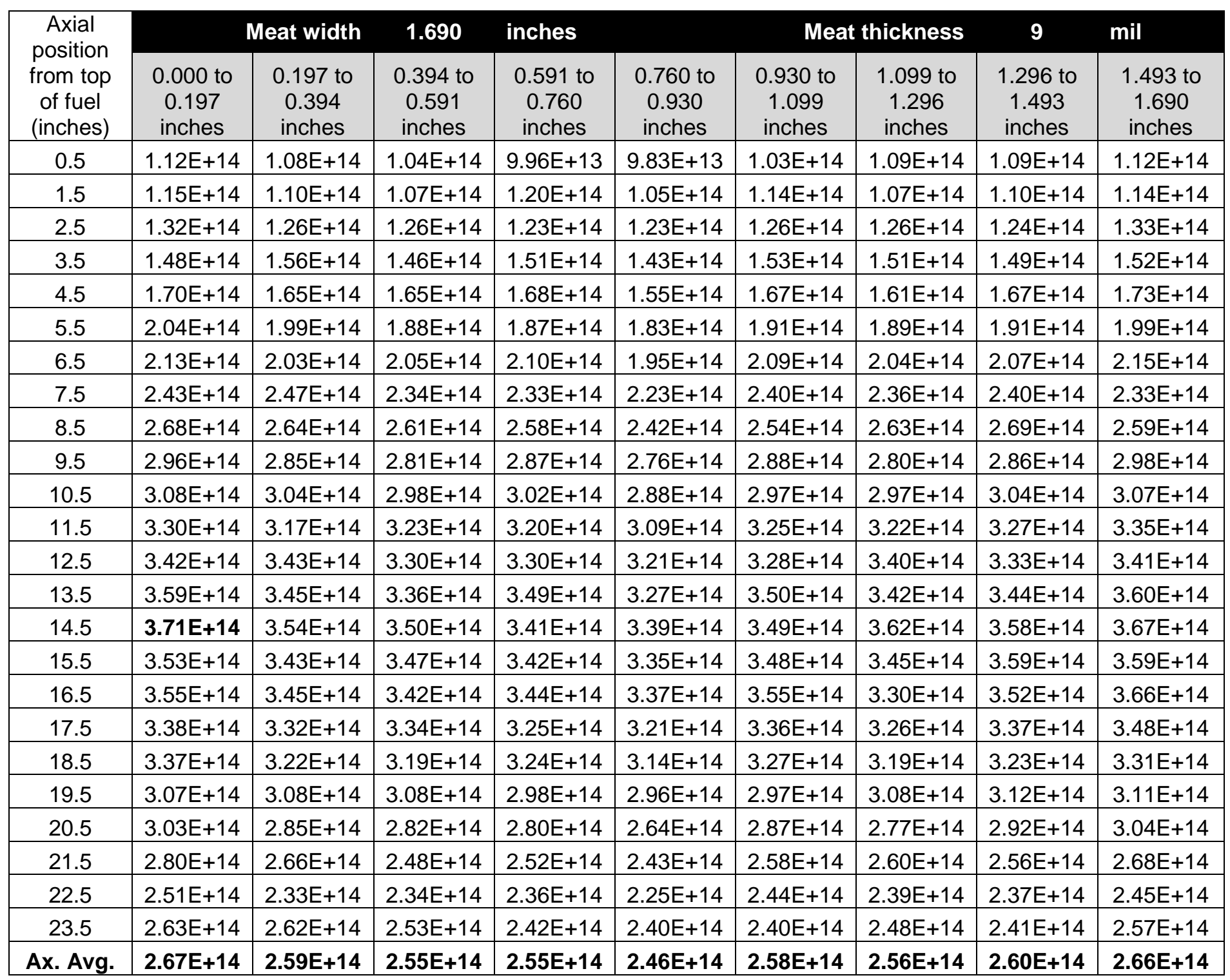




\section{ANL/RERTR/TM-13-1 \\ Revision 1}

Table 3.16. Fission Rate Density (fissions $/ \mathrm{cm}^{3}$-s) in Reference Mixed Burnup Core: Core

7A, Position X4 (170 MWd), No Xe, Plate 1, FT loaded with typical samples.

\begin{tabular}{|c|c|c|c|c|c|c|c|c|c|}
\hline \multirow{2}{*}{$\begin{array}{c}\text { Axial } \\
\text { position } \\
\text { from top } \\
\text { of fuel } \\
\text { (inches) }\end{array}$} & \multicolumn{2}{|r|}{ Meat width } & 1.690 & \multicolumn{2}{|l|}{ inches } & \multicolumn{2}{|c|}{ Meat thickness } & 9 & mil \\
\hline & $\begin{array}{c}0.000 \text { to } \\
0.197 \\
\text { inches }\end{array}$ & $\begin{array}{c}0.197 \text { to } \\
0.394 \\
\text { inches }\end{array}$ & $\begin{array}{c}0.394 \text { to } \\
0.591 \\
\text { inches }\end{array}$ & $\begin{array}{c}0.591 \text { to } \\
0.760 \\
\text { inches }\end{array}$ & $\begin{array}{c}0.760 \text { to } \\
0.930 \\
\text { inches }\end{array}$ & $\begin{array}{c}0.930 \text { to } \\
1.099 \\
\text { inches }\end{array}$ & $\begin{array}{c}1.099 \text { to } \\
1.296 \\
\text { inches }\end{array}$ & $\begin{array}{c}1.296 \text { to } \\
1.493 \\
\text { inches }\end{array}$ & $\begin{array}{c}1.493 \text { to } \\
1.690 \\
\text { inches }\end{array}$ \\
\hline 0.5 & $9.93 E+13$ & $9.86 \mathrm{E}+13$ & $9.83 E+13$ & $1.02 \mathrm{E}+14$ & $9.02 E+13$ & $9.80 E+13$ & $9.60 E+13$ & $1.00 \mathrm{E}+14$ & $1.00 \mathrm{E}+14$ \\
\hline 1.5 & $9.96 \mathrm{E}+13$ & $9.95 \mathrm{E}+13$ & $1.01 E+14$ & $9.84 \mathrm{E}+13$ & $9.57 E+13$ & $1.03 E+14$ & $9.98 \mathrm{E}+13$ & $1.06 \mathrm{E}+14$ & $1.07 \mathrm{E}+14$ \\
\hline 2.5 & $1.15 E+14$ & $1.12 \mathrm{E}+14$ & $1.14 \mathrm{E}+14$ & $1.13 \mathrm{E}+14$ & $1.07 \mathrm{E}+14$ & $1.12 \mathrm{E}+14$ & $1.14 \mathrm{E}+14$ & $1.16 \mathrm{E}+14$ & 1.16E+14 \\
\hline 3.5 & $1.34 \mathrm{E}+14$ & 1.36E+14 & $1.32 E+14$ & $1.35 E+14$ & $1.33 \mathrm{E}+14$ & $1.37 E+14$ & $1.30 \mathrm{E}+14$ & $1.33 E+14$ & $1.32 E+14$ \\
\hline 4.5 & $1.49 \mathrm{E}+14$ & $1.44 \mathrm{E}+14$ & $1.44 \mathrm{E}+14$ & $1.43 E+14$ & $1.45 \mathrm{E}+14$ & $1.44 \mathrm{E}+14$ & $1.43 E+14$ & $1.45 \mathrm{E}+14$ & $1.52 E+14$ \\
\hline 5.5 & $1.67 E+14$ & $1.64 \mathrm{E}+14$ & $1.64 \mathrm{E}+14$ & $1.60 \mathrm{E}+14$ & $1.61 \mathrm{E}+14$ & $1.69 \mathrm{E}+14$ & $1.68 \mathrm{E}+14$ & $1.65 \mathrm{E}+14$ & $1.78 \mathrm{E}+14$ \\
\hline 6.5 & $1.76 \mathrm{E}+14$ & $1.79 \mathrm{E}+14$ & $1.81 E+14$ & $1.82 \mathrm{E}+14$ & $1.65 \mathrm{E}+14$ & $1.78 E+14$ & $1.79 \mathrm{E}+14$ & $1.81 \mathrm{E}+14$ & $1.78 \mathrm{E}+14$ \\
\hline 7.5 & $1.99 E+14$ & $1.94 \mathrm{E}+14$ & $1.89 E+14$ & $2.05 E+14$ & $1.94 \mathrm{E}+14$ & $2.03 E+14$ & $2.01 E+14$ & $2.05 E+14$ & $2.05 E+14$ \\
\hline 8.5 & $2.16 \mathrm{E}+14$ & $2.06 \mathrm{E}+14$ & $2.03 E+14$ & $2.08 \mathrm{E}+14$ & $2.03 E+14$ & $2.06 E+14$ & $2.15 E+14$ & $2.18 \mathrm{E}+14$ & $2.16 \mathrm{E}+14$ \\
\hline 9.5 & $2.32 \mathrm{E}+14$ & $2.32 E+14$ & $2.21 \mathrm{E}+14$ & $2.31 \mathrm{E}+14$ & $2.16 \mathrm{E}+14$ & $2.20 \mathrm{E}+14$ & $2.30 E+14$ & $2.34 \mathrm{E}+14$ & $2.36 E+14$ \\
\hline 10.5 & $2.45 E+14$ & $2.40 \mathrm{E}+14$ & $2.40 \mathrm{E}+14$ & $2.45 \mathrm{E}+14$ & $2.39 \mathrm{E}+14$ & $2.41 E+14$ & $2.42 \mathrm{E}+14$ & $2.57 E+14$ & $2.53 \mathrm{E}+14$ \\
\hline 11.5 & $2.70 E+14$ & $2.67 \mathrm{E}+14$ & $2.66 \mathrm{E}+14$ & $2.64 \mathrm{E}+14$ & $2.50 \mathrm{E}+14$ & $2.67 E+14$ & $2.63 E+14$ & $2.75 E+14$ & $2.84 \mathrm{E}+14$ \\
\hline 12.5 & $2.90 \mathrm{E}+14$ & $2.82 \mathrm{E}+14$ & $2.71 E+14$ & $2.84 \mathrm{E}+14$ & $2.70 \mathrm{E}+14$ & $2.81 E+14$ & $2.84 \mathrm{E}+14$ & $2.91 \mathrm{E}+14$ & $4 \mathrm{E}+14$ \\
\hline 13.5 & $3.03 E+14$ & $2.95 \mathrm{E}+14$ & $2.87 E+14$ & $2.94 \mathrm{E}+14$ & $2.72 E+14$ & $2.91 E+14$ & $2.88 E+14$ & $2.97 E+14$ & $2.95 E+14$ \\
\hline 14.5 & $3.06 E+14$ & $3.01 E+14$ & $3.01 E+14$ & $3.00 \mathrm{E}+14$ & $2.81 \mathrm{E}+14$ & $3.00 E+14$ & $2.94 \mathrm{E}+14$ & $2.99 E+14$ & $3.09 E+14$ \\
\hline 15.5 & $2.94 \mathrm{E}+14$ & $2.92 \mathrm{E}+14$ & $2.97 E+14$ & $2.98 \mathrm{E}+14$ & $2.77 \mathrm{E}+14$ & $2.81 E+14$ & $2.94 \mathrm{E}+14$ & $2.94 \mathrm{E}+14$ & $2.95 \mathrm{E}+14$ \\
\hline 16.5 & $2.97 E+14$ & $2.84 \mathrm{E}+14$ & $2.85 E+14$ & $2.91 \mathrm{E}+14$ & $2.81 \mathrm{E}+14$ & $2.87 E+14$ & $2.89 E+14$ & $3.05 E+14$ & $3.00 \mathrm{E}+14$ \\
\hline 17.5 & $2.85 E+14$ & $2.77 \mathrm{E}+14$ & $2.69 \mathrm{E}+14$ & $2.80 \mathrm{E}+14$ & $2.67 \mathrm{E}+14$ & $2.86 E+14$ & $2.85 E+14$ & $2.77 E+14$ & $2.81 E+14$ \\
\hline 18.5 & $2.75 E+14$ & $2.78 \mathrm{E}+14$ & $2.71 \mathrm{E}+14$ & $2.73 E+14$ & $2.59 \mathrm{E}+14$ & $2.70 E+14$ & $2.81 E+14$ & $2.67 \mathrm{E}+14$ & $2.90 \mathrm{E}+14$ \\
\hline 19.5 & $2.57 E+14$ & $2.52 \mathrm{E}+14$ & $2.56 \mathrm{E}+14$ & $2.50 \mathrm{E}+14$ & $2.43 \mathrm{E}+14$ & $2.52 \mathrm{E}+14$ & $2.52 \mathrm{E}+14$ & $2.62 \mathrm{E}+14$ & $2.61 \mathrm{E}+14$ \\
\hline 20.5 & $2.49 E+14$ & $2.44 \mathrm{E}+14$ & $2.41 E+14$ & $2.47 \mathrm{E}+14$ & $2.32 E+14$ & $2.40 E+14$ & $2.41 E+14$ & $2.51 E+14$ & $2.53 E+14$ \\
\hline 21.5 & $2.34 E+14$ & $2.26 \mathrm{E}+14$ & $2.23 E+14$ & $2.34 \mathrm{E}+14$ & $2.22 \mathrm{E}+14$ & $2.31 E+14$ & $2.31 E+14$ & $2.25 E+14$ & $2.36 E+14$ \\
\hline 22.5 & $2.17 E+14$ & $2.18 \mathrm{E}+14$ & $2.17 E+14$ & $2.13 \mathrm{E}+14$ & $2.02 E+14$ & $2.08 E+14$ & $2.06 \mathrm{E}+14$ & $2.22 \mathrm{E}+14$ & $2.19 \mathrm{E}+14$ \\
\hline 23.5 & $2.37 E+14$ & $2.20 \mathrm{E}+14$ & $2.16 E+14$ & $2.23 \mathrm{E}+14$ & $2.09 \mathrm{E}+14$ & $2.26 \mathrm{E}+14$ & $2.26 \mathrm{E}+14$ & $2.20 \mathrm{E}+14$ & $2.32 E+14$ \\
\hline Ax. Avg. & $2.23 E+14$ & $2.18 E+14$ & $2.16 \mathrm{E}+14$ & $2.20 \mathrm{E}+14$ & $2.09 E+14$ & $2.18 E+14$ & $2.19 E+14$ & $2.23 E+14$ & $2.26 E+14$ \\
\hline
\end{tabular}


Position X5 (0 MWd), Plate 1, BOC

Control Blades at 17.6" (8.4" from top of fuel)

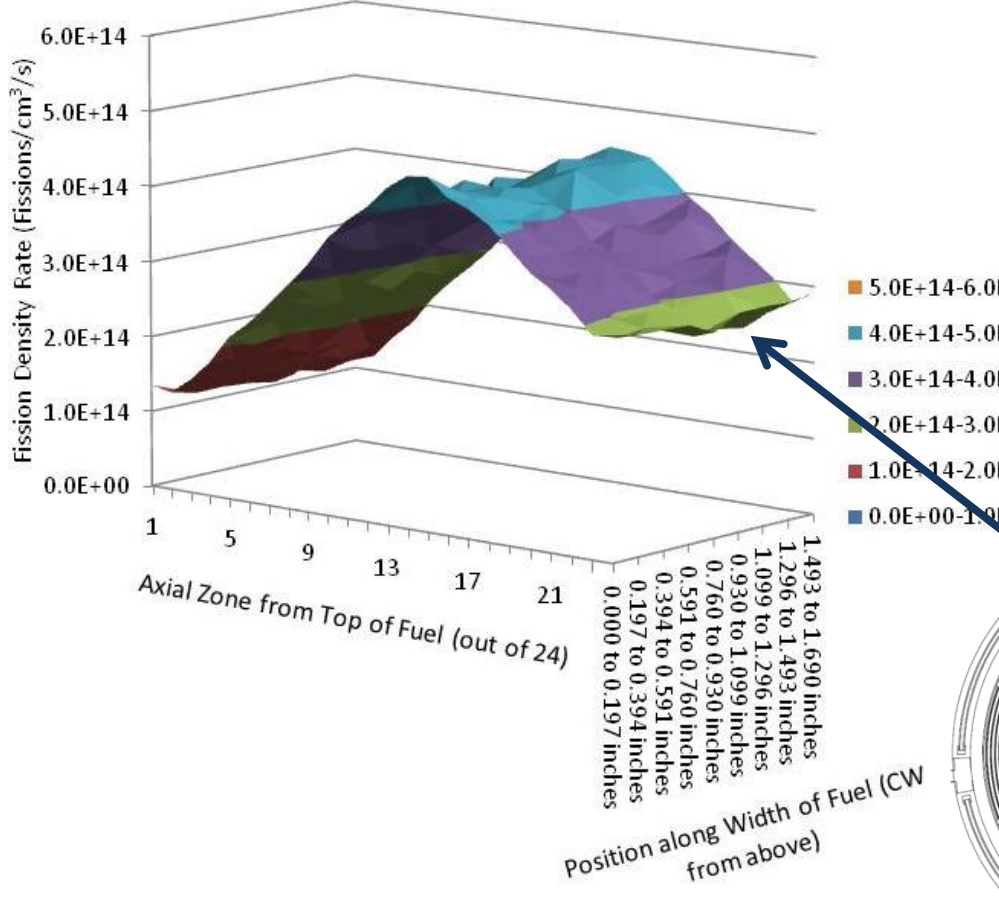

Position X3 (77 MWd), Plate 1, BOC Control Blades at 17.6" (8.4" from top of fuel)

Position X5, 0 MWd, No Xe, Plate 1, FT loaded with typical samples

Position X3, 77 MWd, No Xe, Plate 1, FT loaded with typical samples

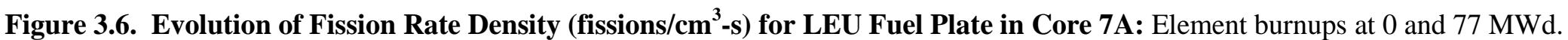




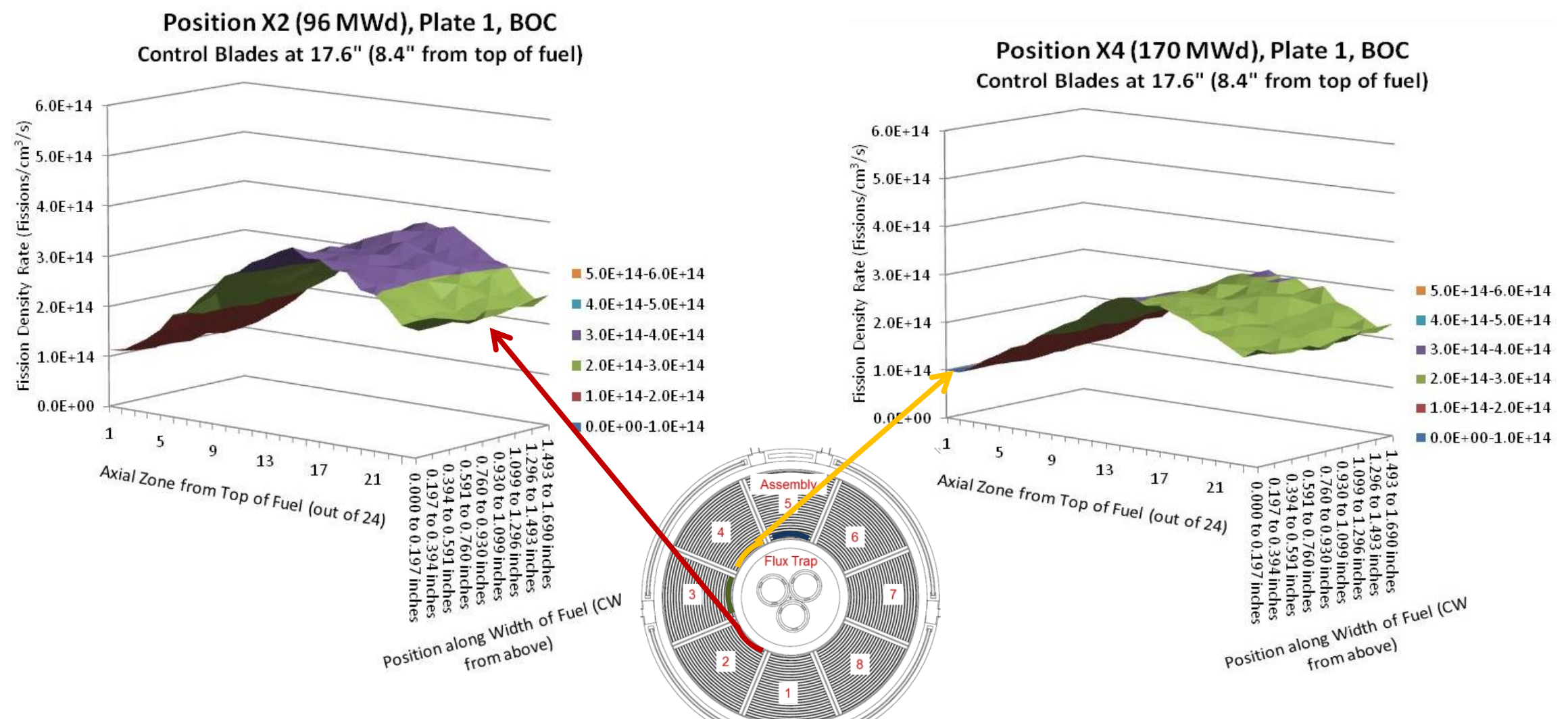

Position X2, 96 MWd, No Xe, Plate 1, FT loaded with typical samples

Figure 3.7. Evolution of Fission Rate Density (fissions $/ \mathrm{cm}^{3}$-s) for LEU Fuel Plate in Core 7A: Element burnups at 96 and 170 MWd. 
Table 3.17. Plate Discharge Fission Density for LEU Fuel.

\begin{tabular}{|c|c|c|c|c|c|}
\hline \multirow[b]{2}{*}{ Plate } & \multirow{2}{*}{$\begin{array}{l}\text { Plate Average } \\
\text { Fission Density } \\
\left(\times 10^{20} \text { fiss } / \mathrm{cm}^{3}\right)\end{array}$} & \multirow[b]{2}{*}{$\begin{array}{l}\text { Axial Burnup } \\
\text { Peaking Factor }\end{array}$} & \multirow[b]{2}{*}{$\begin{array}{c}\text { Azimuthal } \\
\text { Peaking factor }\end{array}$} & \multicolumn{2}{|c|}{ Peak Local Burnup } \\
\hline & & & & $\begin{array}{l}\text { Fission Density } \\
\left(\times 10^{20} \mathrm{fiss} / \mathrm{cm}^{3}\right)\end{array}$ & $\begin{array}{l}\text { Atom \% } \\
\text { Burnup }\end{array}$ \\
\hline 1 & 26.56 & 1.223 & 1.038 & 33.72 & $43.5 \%$ \\
\hline 2 & 20.60 & 1.245 & 1.087 & 27.86 & $35.9 \%$ \\
\hline 3 & 15.68 & 1.254 & 1.144 & 22.50 & $29.0 \%$ \\
\hline 4 & 12.25 & 1.262 & 1.196 & 18.49 & $23.9 \%$ \\
\hline 5 & 10.36 & 1.264 & 1.234 & 16.17 & $20.9 \%$ \\
\hline 6 & 9.34 & 1.263 & 1.251 & 14.76 & $19.0 \%$ \\
\hline 7 & 8.58 & 1.263 & 1.250 & 13.54 & $17.5 \%$ \\
\hline 8 & 8.07 & 1.263 & 1.251 & 12.75 & $16.4 \%$ \\
\hline 9 & 7.72 & 1.263 & 1.247 & 12.16 & $15.7 \%$ \\
\hline 10 & 7.46 & 1.264 & 1.241 & 11.71 & $15.1 \%$ \\
\hline 11 & 7.28 & 1.265 & 1.240 & 11.43 & $14.7 \%$ \\
\hline 12 & 7.15 & 1.266 & 1.243 & 11.26 & $14.5 \%$ \\
\hline 13 & 7.18 & 1.267 & 1.245 & 11.33 & $14.6 \%$ \\
\hline 14 & 7.13 & 1.269 & 1.255 & 11.35 & $14.6 \%$ \\
\hline 15 & 7.11 & 1.271 & 1.264 & 11.42 & $14.7 \%$ \\
\hline 16 & 7.15 & 1.274 & 1.273 & 11.60 & $15.0 \%$ \\
\hline 17 & 7.28 & 1.278 & 1.288 & 11.98 & $15.5 \%$ \\
\hline 18 & 7.52 & 1.282 & 1.302 & 12.55 & $16.2 \%$ \\
\hline 19 & 8.05 & 1.287 & 1.307 & 13.53 & $17.5 \%$ \\
\hline 20 & 8.84 & 1.293 & 1.297 & 14.83 & $19.1 \%$ \\
\hline 21 & 10.34 & 1.297 & 1.268 & 17.01 & $22.0 \%$ \\
\hline 22 & 13.22 & 1.300 & 1.202 & 20.66 & $26.7 \%$ \\
\hline 23 & 18.01 & 1.289 & 1.115 & 25.89 & $33.4 \%$ \\
\hline
\end{tabular}

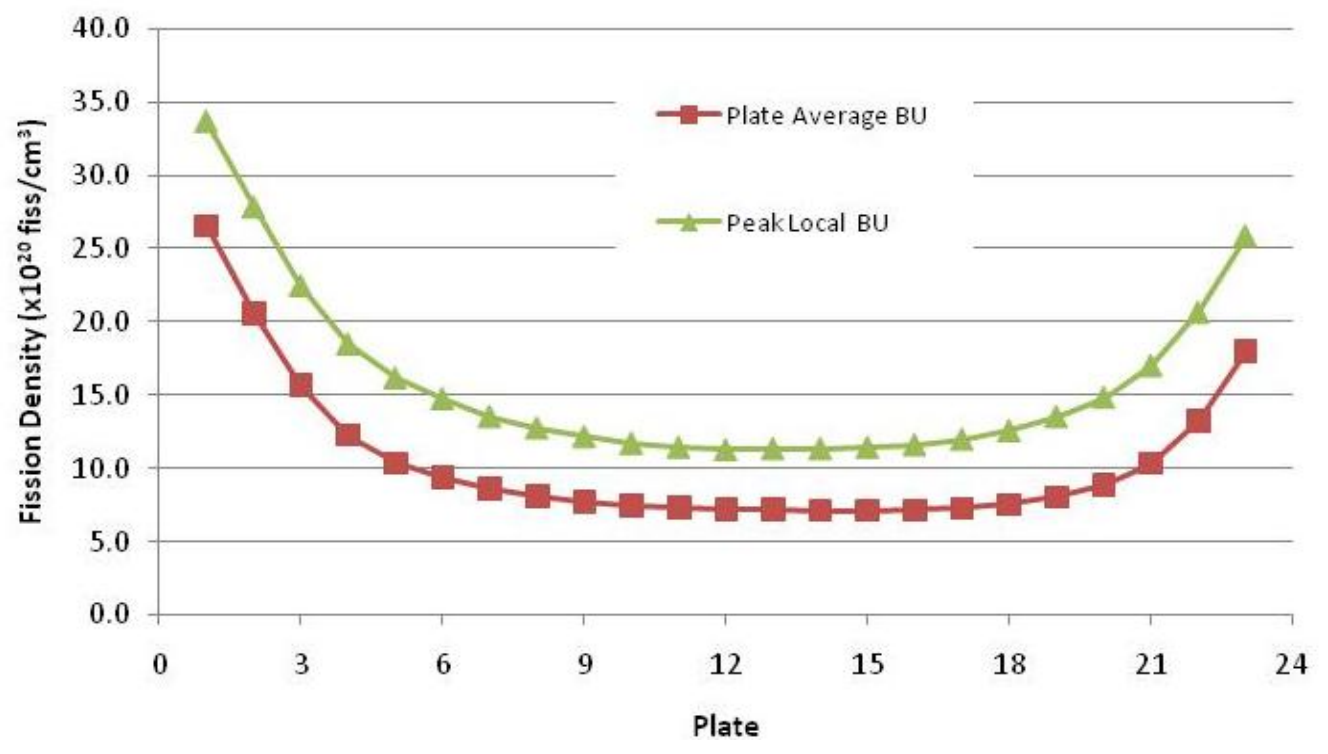

Figure 3.8. Fission Density by Plate in Discharged LEU Fuel. 
Table 3.18. Discharge Fission Density $\left(\mathrm{x10}^{20}\right.$ fissions $\left./ \mathrm{cm}^{3}\right)$ in LEU Fuel Plates.

\begin{tabular}{|c|c|c|c|c|c|c|}
\hline \multirow{2}{*}{ Distance from top of fuel (inches) } & \multicolumn{2}{|c|}{ Plate 1 } & \multicolumn{2}{c|}{ Plate 2 } & \multicolumn{2}{c|}{ Plate 23 } \\
\cline { 2 - 7 } & Average & Peak & Average & Peak & Average & Peak \\
\hline 1.0 & 18.1 & 18.8 & 13.4 & 14.6 & 6.0 & 6.6 \\
\hline 3.0 & 21.0 & 21.9 & 15.8 & 17.1 & 10.6 & 11.8 \\
\hline 5.0 & 25.2 & 26.1 & 19.2 & 20.9 & 16.0 & 17.8 \\
\hline 7.0 & 28.7 & 29.8 & 22.3 & 24.2 & 19.4 & 21.7 \\
\hline 9.0 & 31.2 & 32.4 & 24.4 & 26.5 & 21.6 & 24.1 \\
\hline 11.0 & 32.5 & 33.7 & 25.6 & 27.8 & 22.9 & 25.5 \\
\hline 13.0 & 32.5 & $\mathbf{3 3 . 7}$ & 25.7 & $\mathbf{2 7 . 9}$ & 23.2 & $\mathbf{2 5 . 9}$ \\
\hline 15.0 & 31.1 & 32.3 & 24.5 & 26.6 & 22.7 & 25.3 \\
\hline 17.0 & 28.7 & 29.8 & 22.6 & 24.5 & 21.4 & 23.9 \\
\hline 19.0 & 25.9 & 26.9 & 20.2 & 22.0 & 19.5 & 21.7 \\
\hline 21.0 & 22.8 & 23.6 & 17.5 & 19.0 & 17.1 & 19.1 \\
\hline 23.0 & 21.2 & 22.0 & 16.1 & 17.5 & 15.9 & 17.7 \\
\hline
\end{tabular}
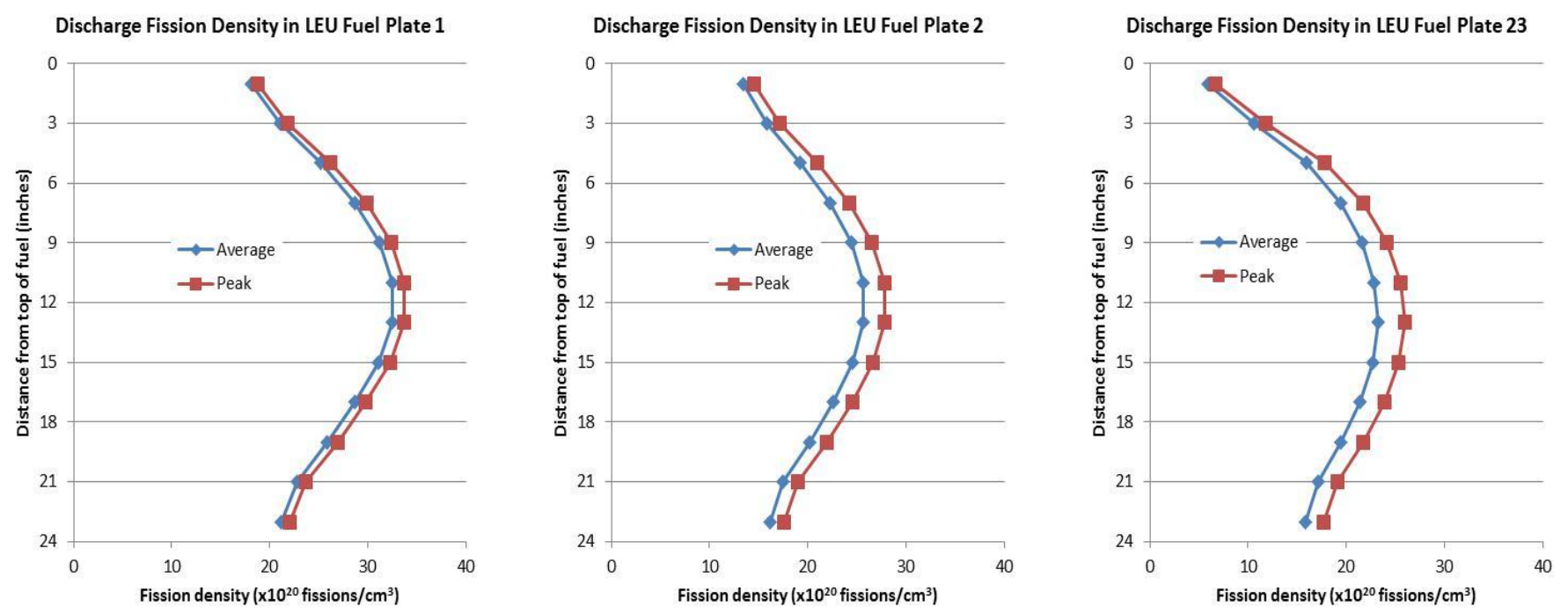

Figure 3.9. Axial Profile of Discharge Fission Density in LEU Fuel Plates.

\subsubsection{Steady-State Temperatures for LEU Fuel in Plates with Peak Irradiation Conditions}

This section presents temperature data for the series of plates containing peak irradiation conditions previously listed in this report. Temperatures were calculated with the aid of the PLTEMP code [11] at a nominal condition of $12 \mathrm{MW}$ for the total reactor power. Previous analyses showed that for the LEU fueled core, $96.4 \%$ of the energy from fission is deposited in the primary system, with the balance being deposited in ex-core materials such as the beryllium reflector that surrounds the core. Consequently, since the model represented only the primary coolant system of the MURR, the power distributions were normalized to a core power of $11.57 \mathrm{MW}$. Table 3.19 summarizes the core operating parameters, which are the anticipated nominal operating conditions of the MURR with LEU fuel. 
Table 3.19. Nominal MURR Core Operating Parameters with LEU Fuel.

\begin{tabular}{|l|c|}
\hline Total Reactor Power & $12 \mathrm{MW}$ \\
\hline Fraction of Power Deposited in Primary Coolant System & $96.4 \%$ \\
\hline Total Core Power & $11.57 \mathrm{MW}$ \\
\hline Coolant Inlet Temperature & $120^{\circ} \mathrm{F}\left(48.9^{\circ} \mathrm{C}\right)$ \\
\hline Total Core Coolant Flow Rate & $3800 \mathrm{gpm}$ \\
\hline Pressurizer Pressure & $84 \mathrm{psia}$ \\
\hline
\end{tabular}

The construction of the LEU fuel plates is described in Section 2, and consists of a U-10Mo fuel foil clad with a thin (1 mil nominal) layer of zirconium and a layer of Al-6061 aluminum on each foil face. The zirconium acts as an interaction barrier between the fuel meat and aluminum. Dimensions for each fuel plate in the element are given in Table 2.1. While the fuel is being irradiated, a thin layer of oxide gradually forms on the heated surfaces of the clad and thickens with hours of operation. The oxide layer growth rate and thermal treatment are described later in this section.

The thermal conductivity values of the LEU fuel plate materials are summarized in Table 3.20. These values are taken from Reference 2. Because the fuel meat thermal conductivity decreases with burnup, two values are provided, one for the fresh fuel and another for the fuel when it is ready to be discharged. Between these two extremes, linear interpolation based on fuel burnup is used in the PLTEMP model. The thermal conductivity of the fresh LEU fuel was calculated in Reference 2 based on a fuel temperature of $200{ }^{\circ} \mathrm{C}$ and taken at the lower end of the tolerance range. For temperatures less than $200{ }^{\circ} \mathrm{C}$, the thermal conductivity of the fuel meat will be smaller than that reported in Table 3.20 and the PLTEMP calculation will underpredict the meat temperature, but this would not represent a safety issue as long as the fuel can withstand temperatures below $200{ }^{\circ} \mathrm{C}$ without sustaining any damage or degradation. For the irradiated fuel, the thermal conductivity is conservatively based on a fuel burnup of $40 \times 10^{20}$ fissions $/ \mathrm{cm}^{3}$. This is well above the peak LEU fuel burnup of $33.7 \times 10^{20}$ fissions $/ \mathrm{cm}^{3}$ in Table 3.18 . Likewise, conservative values for the thermal conductivities of the zirconium layer and the AL-6061 aluminum, and a representative value for thermal conductivity of the oxide layerm were identified in Reference 2 and used in the present analysis.

Table 3.20. Thermal Conductivity Values for LEU Fuel Plate Materials (W/m-C).

\begin{tabular}{|l|c|c|}
\hline Material & $\begin{array}{c}\text { Fresh } \\
(\mathbf{0} \text { MWd })\end{array}$ & $\begin{array}{c}\text { Discharged } \\
(\mathbf{1 8 0} \text { MWd })\end{array}$ \\
\hline Fuel meat & 16.2 & 11.3 \\
\hline Zirconium layer & 19 & 19 \\
\hline AL-6061 aluminum & 150 & 150 \\
\hline Oxide layer & 2.25 & 2.25 \\
\hline
\end{tabular}

When thermal-hydraulic safety calculations are performed, hot channel factors are applied to account for factors such as the statistical variations in manufacturing of the fuel element and the uncertainty of the method used for the neutronics calculation, which would affect the heat flux realized in the reactor. This then ensures that the thermal-hydraulic safety margins are maintained under even the most extreme conditions. However, the goal here is to determine the nominal temperatures of the fuel components under normal operating conditions. These temperatures serve as a nominal basis for comparison during conceptual design of fuel irradiation experiments. Applicable engineering hot channel uncertainty factors will be required. However, these will be used in later stages of the design of the fuel irradiation experiments in conjunction with analysis of uncertainties and tolerances in the fuel irradiation experiments. As such, hot channel factors related to the fuel manufacturing and calculational uncertainty were not included in the temperature analysis performed here. However, the impact of the coolant 
channel restriction that may occur with depletion of the fuel under normal operating conditions, as well as the increased thermal resistance across the clad due to the growth of an oxide layer on the surface of the fuel plates were included in the temperature analysis. This methodology was presented as a part of prior design activities [6].

The coolant channels between the fuel plates will become constricted as a result of three phenomena. First, as the fuel undergoes fission, swelling of the fuel meat due to fission gas production will occur. The second phenomenon is the effect of irradiation-enhanced creep of the fuel meat which will cause localized bulging of the fuel plate near the edges, which are constrained by the clad at the edges next to the side plates. Third, oxide growth from the aluminum-water reaction will constrict the coolant channel. The amount of oxide growth on the fuel plate depends on the temperature at the water-plate surface, operating time, water $\mathrm{pH}$ level, and any protective coating placed on the outside surface of the fuel clad.

The fuel swelling and fuel creep effects were assessed from experimental data reported in References 12 and 13. Based on correlations in the references, the calculated maximum increase in the fuel meat thickness over the life of the LEU fuel from these two phenomena will be 4 mil. For coolant channels 2 through 23 of the LEU element, which are each bounded by two fuel plates, it was assumed that the channel will be restricted by 4 mil at the end-of-life from these effects $(2$ mil growth into the coolant channel from each plate). For channels 1 and 24, the constriction will be half that amount.

The growth of an oxide layer on the surface of the aluminum clad causes both a restriction of the coolant channel, as well as increasing the thermal resistance of the clad, raising the $\Delta \mathrm{T}$ across the clad material. A correlation of the oxide growth rate developed by Griess [14] was modified to take into account the specific operating conditions of the MURR. The correlation parameters were altered based on experimental measurements of the oxide layer thickness formed on a MURR HEU fuel element. The resulting oxide growth correlation for the LEU fuel in the MURR is shown in Figure 3.10. The LEU fuel in MURR is expected to reach a discharge burnup of $180 \mathrm{MWd}$ after 2,880 full-power hours of operation. The correlation shown in Figure 3.10 was used to calculate the oxide thickness and associated thermal resistance of the clad for each fuel element in the PLTEMP model.

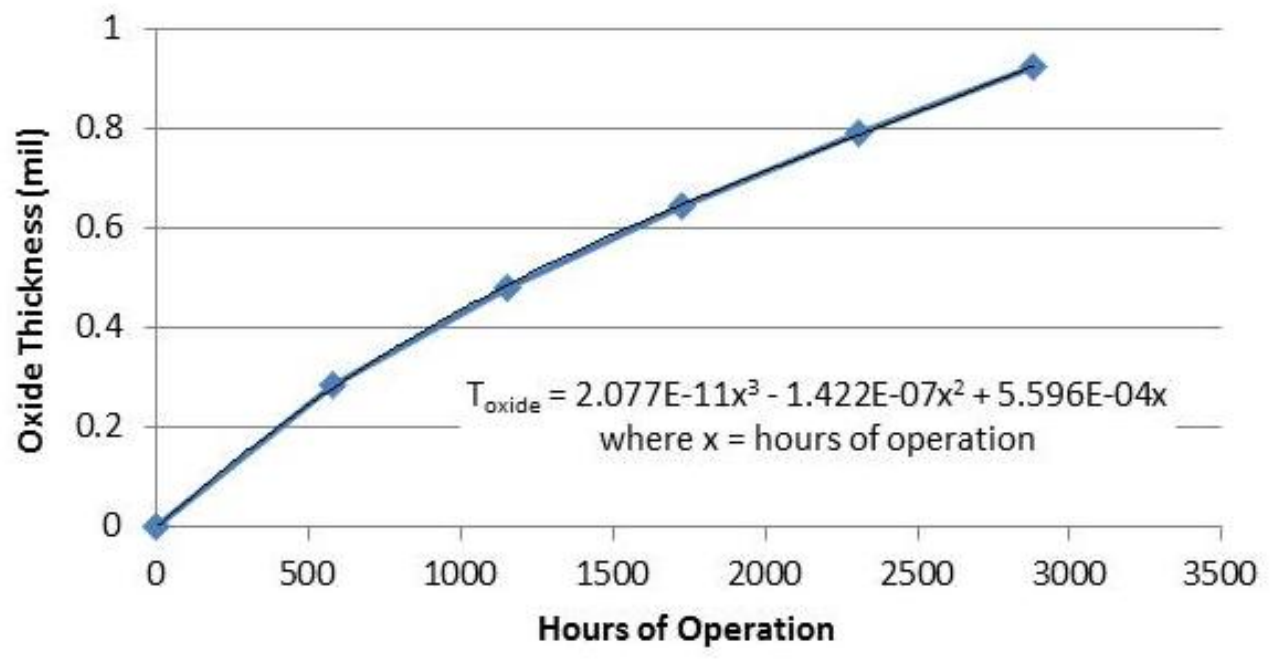

Figure 3.10. Oxide Growth Rate Correlation for LEU Fuel Element in MURR.

While the correlation indicates that the oxide thickness at the discharge burnup will be less than 1 mil, it was conservatively assumed for the purpose of estimating the channel restriction that the oxide layer 
grows to $2 \mathrm{mil}$ at the end of the fuel life. The oxide layer will tend to flake off the fuel plates at thicknesses greater than 2 mil. Consequently, the coolant channel restriction due to oxide growth will be a maximum of 4 mil for channels between fuel plates ( 2 mil oxide on each plate adjacent to the channel), and 2 mil restriction for channels 1 and 24 that are heated by only one plate.

Thus, the total maximum channel restriction due to the combined effects of fuel swelling, irradiationenhanced creep, and oxide growth for the LEU fuel in MURR will be 8 mil for channels that are heated by two fuel plates (channels 2-23), and 4 mil for channels heated by only one plate (channels 1 and 24). This affect was included in the PLTEMP model, with the assumption that the channel restriction increases linearly with burnup over the life of the fuel from 0 to $180 \mathrm{MWd}$.

Temperatures for azimuthal stripes were calculated for the various cores using the power distributions in Section 3.3. As discussed in Section 3.2 above, the hot stripe is one of the $5 \mathrm{~mm}$ azimuthal power stripes along the edge of the fuel meat (adjacent to the unfueled portion of the plate that is swaged into the side plate). It is conservatively assumed that there was no coolant mixing between adjacent fueled or unfueled stripes. PLTEMP simultaneously analyzes the entire core in order to obtain the limiting temperatures in each fuel element. After a complete thermal solution is obtained for this model, the code applies appropriate azimuthal peaking factors to all of the individual bulk coolant, film, and material temperature rises determined by the model. Thus, in addition to plate azimuthally-averaged temperatures, peak local temperatures are presented in this report which represent a region $5 \mathrm{~mm}$ azimuthally and $2.54 \mathrm{~cm}$ axially.

Tables 3.21 to 3.24 provide the steady-state temperatures of plates with various peak irradiation conditions found in the MURR LEU U-10Mo fuel design. In addition to the peak temperature, which is found in the fuel, the corresponding peak temperature of the cladding and the peak plate surface temperature for the same plate are also listed. The peak temperature in the cladding is for the region including the aluminum and zirconium layers which clad the fuel. The plate surface is the interface where the coolant meets the oxide layer, if this layer exists, or the clad surface if there is no oxide layer in the model. It should be noted that this report does not treat the temperatures due to conditions during offnominal or transitory conditions such as found in an analysis of limiting safety system setting (LSSS) or transient and accident scenarios. Thus, the peak local temperatures present nominal steady-state conditions relevant for design of steady-state irradiation experimental conditions. The axial location of the peak local temperatures are approximately two-thirds of the distance down the fueled region at, or slightly below, the axial location of peak power.

Temperatures of the plate containing the maximum heat flux as shown in Table 3.4 (core 5B1) are listed in Table 3.23. However, as listed in Table 3.24, the maximum fuel temperature of all cores was found in plate 22 of an end of life, xenon-free, element in core 7A1. Although the heat flux is lower in this core compared to core 5B1 which contains all fresh fuel, a modestly higher peak fuel temperature is observed due to constriction of the channel from oxide formation and fuel deformation, and also the increased temperature rise due to oxide growth on the clad surface. 
Table 3.21. Steady-State Temperatures of LEU Plate with Maximum Fission Rate Density: Fresh LEU Element in Core 5B1, Position X7, No Xe, Plate 1, Empty FT.

\begin{tabular}{|l|c|c|c|}
\hline Temperature, ${ }^{\mathbf{o}} \mathbf{F}\left({ }^{\mathbf{}} \mathbf{C}\right)$ & Peak Fuel & Peak Clad & Plate Surface \\
\hline Plate Average (fueled area of plate) & $205(96)$ & $198(92)$ & $189(87)$ \\
\hline Peak Local (nominal without uncertainties) & $244(118)$ & $234(112)$ & $221(105)$ \\
\hline
\end{tabular}

Table 3.22. Steady-State Temperatures of LEU Plate with Maximum Mixed Core Fission Rate Density: Fresh LEU Element in Core 7A, Position X5, No Xe, Plate 1, FT loaded.

\begin{tabular}{|l|c|c|c|}
\hline Temperature, ${ }^{\mathbf{}}{ }^{\mathbf{F}}\left({ }^{\mathbf{}} \mathbf{C}\right)$ & Peak Fuel & Peak Clad & Plate Surface \\
\hline Plate Average (fueled area of plate) & $199(93)$ & $192(89)$ & $185(85)$ \\
\hline Peak Local (nominal without uncertainties) & $234(112)$ & $223(106)$ & $210(99)$ \\
\hline
\end{tabular}

Table 3.23. Steady-State Temperatures of LEU Plate with Maximum Heat Flux: Fresh LEU Element in Core 5B1, Position X6, No Xe, Plate 23, Empty FT.

\begin{tabular}{|l|c|c|c|}
\hline Temperature, ${ }^{\mathbf{o}} \mathbf{F}\left({ }^{\mathbf{}} \mathbf{C}\right)$ & Peak Fuel & Peak Clad & Plate Surface \\
\hline Plate Average (fueled area of plate) & $203(95)$ & $190(88)$ & $183(84)$ \\
\hline Peak Local (nominal without uncertainties) & $282(139)$ & $257(125)$ & $241(116)$ \\
\hline
\end{tabular}

Table 3.24. Steady-State Temperatures of LEU Plate with Maximum Fuel Temperature: Depleted LEU Element in Core 7A1, Position X8, No Xe, Plate 22, FT loaded.

\begin{tabular}{|l|c|c|c|}
\hline Temperature, ${ }^{\mathbf{o}} \mathbf{F}\left({ }^{\mathbf{o}} \mathbf{C}\right)$ & Peak Fuel & Peak Clad & Plate Surface \\
\hline Plate Average (fueled area of plate) & $226(108)$ & $207(97)$ & $183(84)$ \\
\hline Peak Local (nominal without uncertainties) & $297(147)$ & $264(129)$ & $223(106)$ \\
\hline
\end{tabular}




\subsection{LEU IRRADIATION PARAMETERS WITH UNCERTAINTIES}

Maximum local parameters calculated for steady-state LEU cores in the most limiting configurations were presented in Section 3 without uncertainties. Safety analyses have accounted for uncertainties including tolerances in geometry and materials as described in Table 2.2. Table 4.1 summarizes the data from Section 3 along with applicable hot channel factors (HCFs) based upon data in Table 2.2 and other uncertainty assumptions made in the safety analyses. The table lists total HCFs which combine individual HCF components multiplicatively, as was assumed in safety analyses to represent the maximum values. Table 4.1 uses these HCFs for both the maximum licensed and LSSS power levels.

Table 4.1. Maximum Irradiation Parameters and Uncertainties Assumed for LEU Fuel.

\begin{tabular}{|c|c|c|c|}
\hline Core Condition & $\begin{array}{c}\text { Fission Rate } \\
\text { Density } \\
\text { (fissions } / \mathrm{cm}^{3}-\mathrm{s} \text { ) }\end{array}$ & $\begin{array}{c}\text { Fission } \\
\text { Density } \\
\left(\text { fissions } / \mathrm{cm}^{3}\right) \\
\end{array}$ & $\begin{array}{c}\text { Heat } \\
\text { Flux } \\
\left(\mathrm{W} / \mathrm{cm}^{2}\right)\end{array}$ \\
\hline $\begin{array}{l}\text { Maximum Licensed Power } \\
\text { without HCFs (12 MW) }\end{array}$ & $5.09 \mathrm{E}+14$ & $3.37 \mathrm{E}+21$ & 225.58 \\
\hline \multicolumn{4}{|l|}{ Hot Channel Factors } \\
\hline $\begin{array}{l}\text { Fuel Meat Thickness \& } \\
{ }^{235} \text { U Homogeneity (Local)* }\end{array}$ & $* *$ & - & 1.15 \\
\hline Calculated Power Distribution & 1.10 & - & 1.10 \\
\hline Power Measurement & $1.05^{+}$ & - & $1.05^{+}$ \\
\hline Total & 1.16 & $1.25^{++}$ & 1.33 \\
\hline $\begin{array}{l}\text { Maximum Licensed Power } \\
\text { with HCFs (12 MW) }\end{array}$ & $5.9 \mathrm{E}+14$ & \multirow[t]{2}{*}{$4.2 \mathrm{E}+21$} & 300 \\
\hline LSSS Power (15 MW) with HCFs & $7.0 \mathrm{E}+14$ & & 357 \\
\hline
\end{tabular}

Safety analyses have applied HCFs to heat flux for combined fuel thickness and local ${ }^{235} \mathrm{U}$ homogeneity, and for an uncertainty in calculated power distribution. Power measurement uncertainty has not been included in the LEU safety analyses since the reactor power trip setting is lowered by the amount of the uncertainty during operation of the MURR reactor [2]. However, for the purposes of estimating the impact on parameters for an irradiation experiment, a 5\% uncertainty was applied only to maximum licensed power with HCFs as shown in Table 4.1.

Since heat flux was used to determine thermal hydraulic margin in the reactor, safety analyses have not required direct calculation of the fission rate, and associated HCFs. For fission rate, the HCF in power distribution was assumed to be the same as for heat flux. However, for fission rate density the combined thickness and homogeneity HCF would be dominated by the homogeneity of the fuel rather than the tolerance on thickness. Homogeneity uncertainty is estimated to be significantly less than other applicable HCFs, and so this HCF component is neglected.

An uncertainty of $25 \%$ has been assigned to the fission density, which accounts primarily for adjustments in the fuel cycle. Temperature uncertainties are not listed in this table since these are not a current focus of the irradiation experiment design in a test reactor. 


\subsection{SUMMARY OF NOMINAL MURR IRRADIATION PARAMETERS}

The preceding sections provide plate performance data for a number of core states that could exist during steady-state operations of the MURR as examined in Reference 1. The plates presented were selected from LEU elements under the conditions that are expected in steady-state operations in the MURR to yield the highest plate heat flux, fuel and cladding temperatures, fission rate density, and cumulative fission density. It should be noted that this data represents, within the local plate shapes specific to MURR, peak local performance parameters expected for the MURR LEU core based on nominal steadystate conditions without engineering hot channel uncertainty factors. Manufacturing tolerances and other uncertainties in reactor geometry and materials are also presented and used to estimate the steady-state upper bound of key irradiation parameters with uncertainties.

As discussed in this report, the design and safety analysis of the proposed MURR LEU element has been performed within the context of an ongoing and larger campaign to qualify U-10Mo fuel for use in various reactors. While the set of irradiation parameters presented here provide data on select plates of interest to fuel irradiation experiments, it should be noted that further data may be useful among the wide variety of individual plate irradiation conditions that would be present in MURR LEU cores. Thus, further cooperative work should continue between MURR and the RC, FD and FFC pillars to ensure that appropriate data is available to plan irradiations which include peak conditions, as well as within plate distributions of irradiation parameters relevant to fuel performance. 


\section{REFERENCES}

1. Stillman, J. A., et al, Technical Basis in Support of the Conversion of the University of Missouri Research Reactor (MURR) Core from Highly-Enriched to Low-Enriched Uranium - Core Neutron Physics, ANL/RERTR/TM-12-30, September 2012.

2. Feldman, E. E., et al., Technical Basis in Support of the Conversion of the University of Missouri Research Reactor (MURR) Core from Highly-Enriched to Low-Enriched Uranium - Steady-State Thermal-Hydraulic Analysis, ANL/RERTR/TM-12-37, Argonne National Laboratory, 2012.

3. Letter Request to USNRC, "Application for Unique Purpose Exemption from Conversion from HEU Fuel, Facility License No. R-103," University of Missouri Research Reactor, September 1986; and supplemented by Letter Response to USNRC Request for Additional Information Supporting the Unique Purpose Exemption Request, February 1987.

4. Foyto L., et al., Preliminary Safety Analysis Report Methodologies and Scenarios for LEU Fuel Conversion of the University of Missouri Research Reactor (MURR), MURR Technical Data Report No. 0128, August 2011.

5. Specification TRTR-4 for University of Missouri-Columbia Fuel Elements Assembled for University of Missouri Research Reactor, Revision 4, June 8, 1994.

6. Stillman, J. A., et al, Conceptual Design Parameters for MURR LEU U-Mo Fuel Conversion Design Demonstration Experiment, ANL/RERTR/TM-12-38, Rev. 1, March 2013.

7. J. Rest, et al, U-Mo Fuels Handbook, Version 1.0, RERTR Program, Argonne National Laboratory, June 2006.

8. D. E. Burkes, G. S. Mickum, and D. M. Wachs, Thermophysical Properties of U-10Mo Alloy, INL/EXT-10-19373, November 2010.

9. Peters, Nickie and Kutikkad, Kiratadas, Spatial Distribution of the Effective Fission Energy Deposition Within the MURR Core: HEU vs. LEU Fuel Comparison, University of Missouri, 2012.

10. Tzanos, C. and Stillman, J., Effect of Lateral Conduction on the Azimuthal Distribution of Heat Flux in the Hot Plate of a Research Reactor, ANS Summer Meeting, June 2012.

11. Olson, A. P. and Kalimullah, A User's Guide to the PLTEMP/ANL Code, Version 4.1, ANL/RERTR/TM-11-22, Nuclear Engineering Division, Argonne National Laboratory, April 9, 2011.

12. Kim, Y. S. and Hofman, G. L., Fission Product Induced Swelling of U-Mo Alloy Fuel, Journal of Nuclear Materials 419 (2011) 291-301.

13. Hofman, G. L, et al, Fission Induced Swelling and Creep of Uranium-Molybdenum Alloy Fuel, 13th International Topical Meeting on Research Reactor Fuel Management (RRFM09), Vienna, Austria, March 22-25, 2009.

14. Griess, J. C., et al, Effect of Heat Flux on the Corrosion of Aluminum by Water, Oak Ridge National Laboratory, 1961. 
Argonne

Nuclear Engineering Division

Argonne National Laboratory

9700 South Cass Avenue, Bldg. 208

Argonne, IL 60439

www.anl.gov

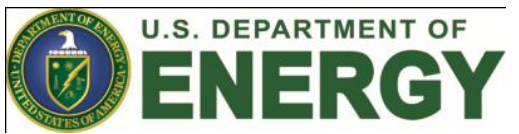

Argonne National Laboratory is a U.S. Department of Energy laboratory managed by UChicago Argonne, LLC 